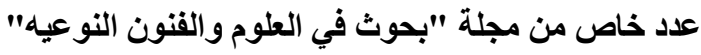

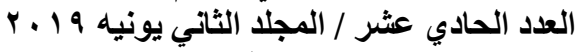

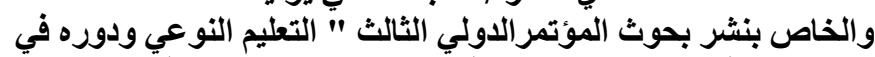

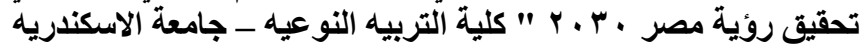

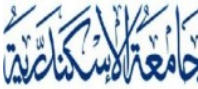

ALEXANDRIA

U N I V ER S I T Y

AlexU Press

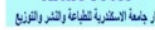

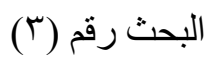

\title{
سياسات الإلتزام البيئى لرية الأسرة وإنعكاسها على الخبرات البيئية للأبناء فى ضوء تحديات التتمية المستدامة
}

أ.م.د/ رغدة محمود أحمد

أستاذ مساعد بقسم إدارة مؤسسات الأسرة والطفولة

كلية الإقتصاد المنزلي-جامعه حلوان
أ. أ.د -د/ وئام على أمين

أستاذ مساعد بقسم إدارة مؤسسات الأسرة والطفولة

كلية الإقتصاد المنزلي - جامعه حلوان 
عدد خاص من مجلة "بحوث في العلوم والفنون النوعيه"

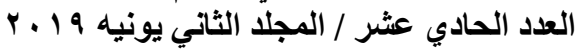

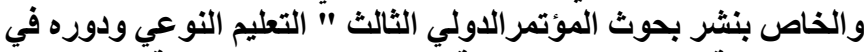

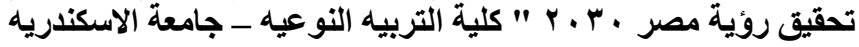

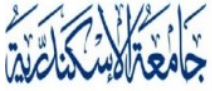

ALEXANDRIA

UN I VER S I T Y

Alexu Press

\section{الملخص}

يهدف البحث إلى دراسة إنعكاس سياسات الإلتزام البيئى لربة الأسرة على الخبرات

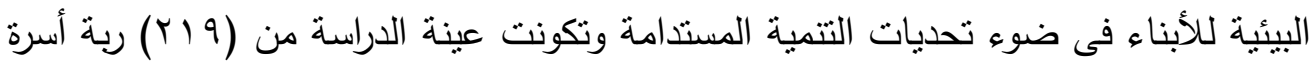

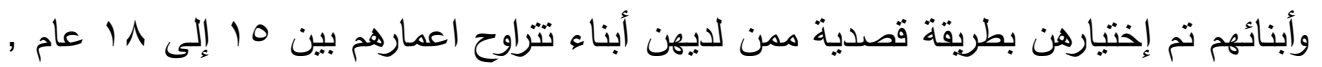

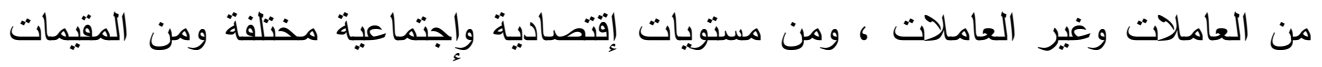

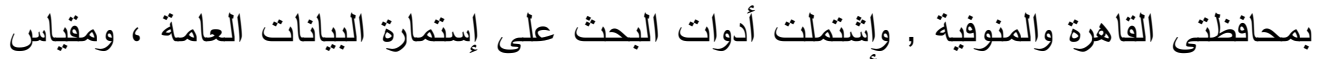

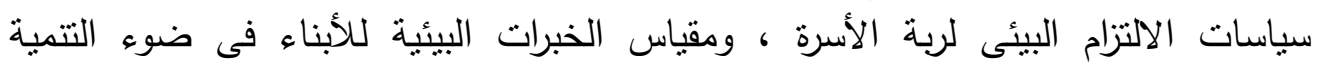

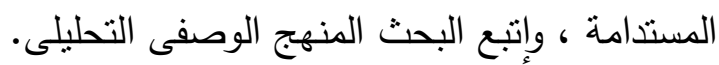

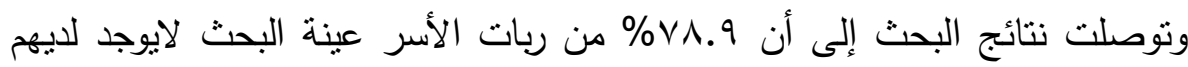

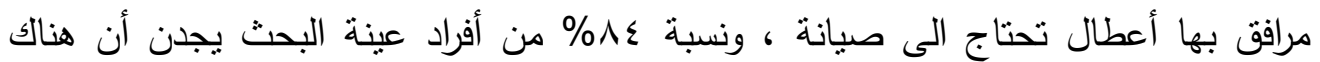

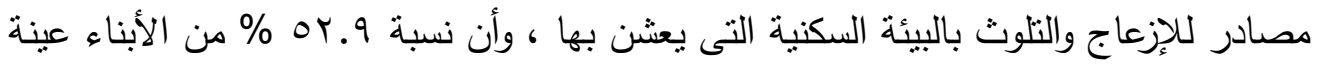

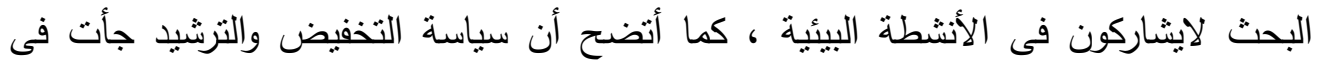

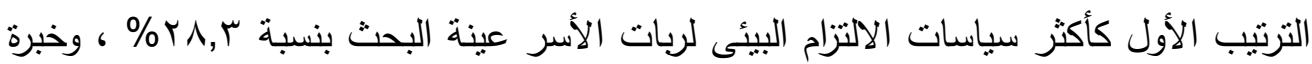

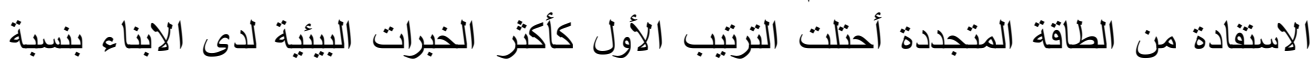

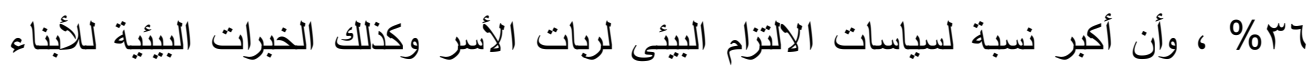

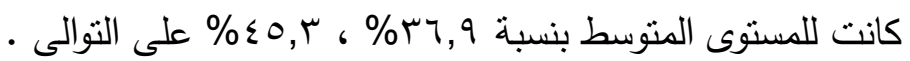

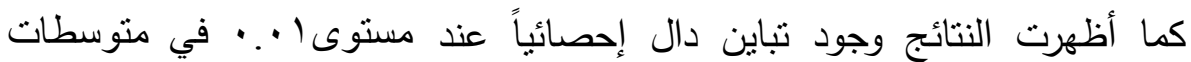

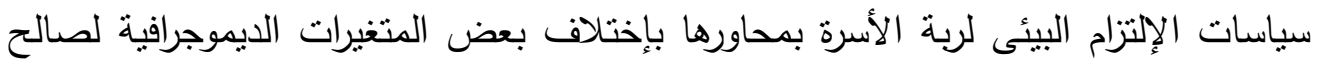

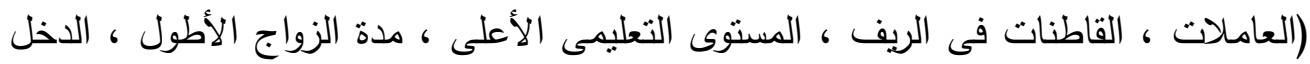

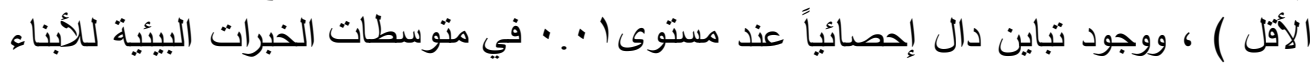

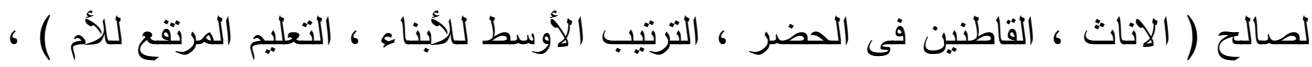

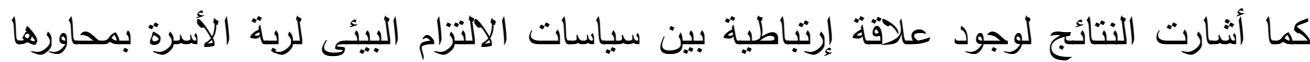

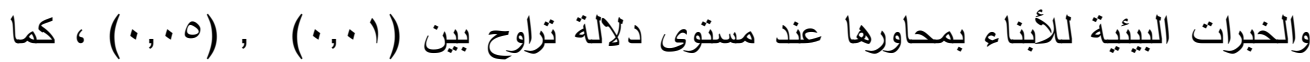

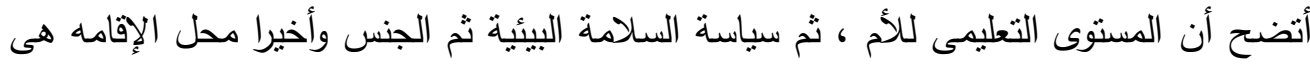

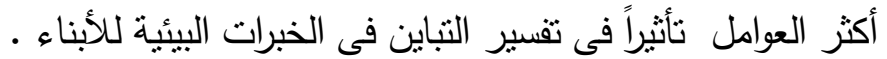


عدد خاص من مجلة "بحوث في العلوم والقنون النوعيه" العزيه

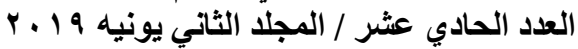

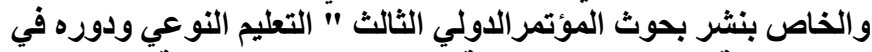

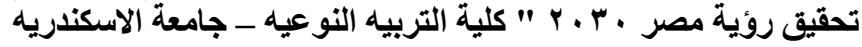

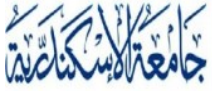

ALEXANDRIA

U N I VER S I T Y

AlexU Press

vip

\section{مقدمة البحث:}

يشهد العالم الآن اهتماما متزايداً بقضايا التتمية المستدامة وبخاصة في الدول النامية التي تحاول اللحاق بركب التقدم وهذا يتطلب بذل الجهود المكثقة لاستغلال كافة الموارد المادية والبشرية على أفضل وجه ممكن لتحقيق النمو الاقتصادي والاجتماعي المنشودين والتمكن من إثباع كافة الحاجات الإنسانية (برنامج الأمم المتحدة الإنمائى ، . . . ب) .

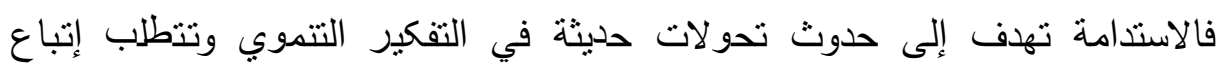
سياسات محلية وإجراءات وحوافز تدفع إلى التشجيع على السلول الاقتصادي" المرشد بيئيًا" ، مما يسمح بتحقيق المكاسب المرتقبة على المدى القصير والطيويل وفق المـوارد

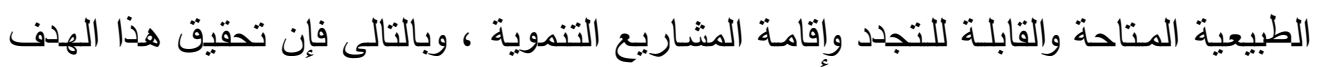
لا يقتصر فقط على الحاجة للمعرفة المحلية وإنما بالمشاركة الكاملة للمستقيدين في عملية

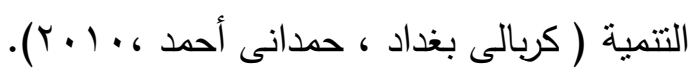

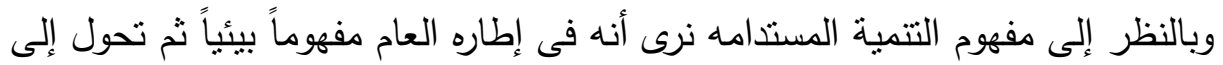

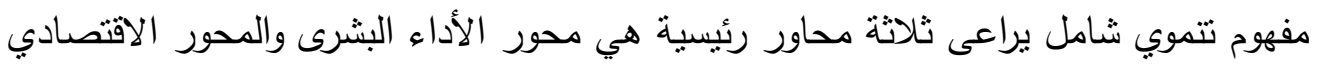
والمحور البيئي السكنى وتتحقق هذه التتمية لهذه المحاور الثلاثة من خلال النظم الإدارية لهنية

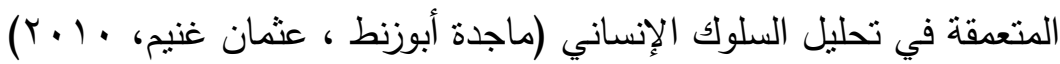
فالتتمية المستدامة تتطلب صبانة البيئة وحمايتها وأن يكون موقف الإنسان من البيئة

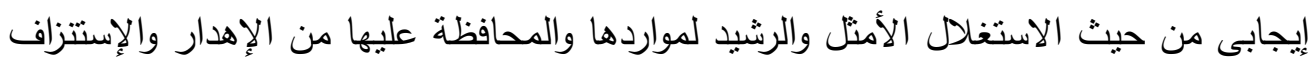

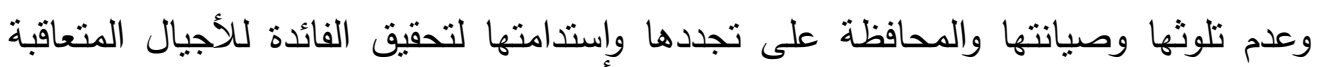

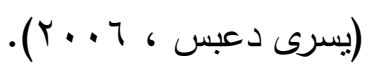

كما أن قضية التتمية المستدامة أصبحت مطلباً ضرورياً لمواجهة السلوك الإستهلاكى غير الرشيد للأفراد والمجتمعات منمثلاً فى تحقيق الرفاهية الإقتصادية من خلال الاستخدام المفرط فى الموارد وكذلك النزعة الاستهلاكية من خلال استهلاك السلع المادية لتحقيق السعادة التهاة 
عدد خاص من مجلة "بحوث في العلوم والقنون النوعيه" التوبه

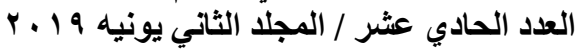

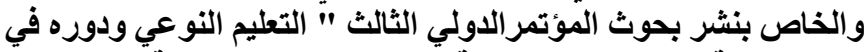

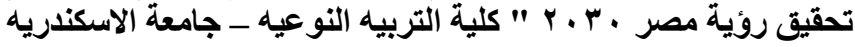

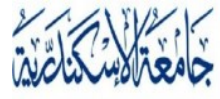

ALEXANDRIA

U N I V E R S I T Y

AlexU Press

(i)

وذللك لأنها العملية التى تهتم بتحقيق التكافؤ المتصل الذى يضدن إتاحة نفس الفرص التتموية

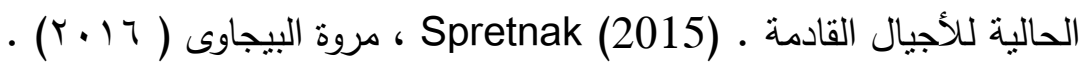

كذلك أصبحت قضية حماية البيئة تستدعى إنتباه الكثير من الدول المتقدمه والمتخلفة على حد السواء لما لها من أهمية على صحة البيئة ومن ثم على صحة الإنسان كما أصبح من الواجب الاهتمام بها بصورة أكبر لكونها قضية الساعة (كسيرة أمينة , 11 (Y) ، حيث نالت إهتمام دول العالم وسارت مركز النقاشات القائمة من طرف المجتمع الدولى (رمضان عبدالمجيد , ( • ( ) , فكثرت بذلك الدراسات حول مناقشة مشكلة حماية البيئة وأبرمت العديد من المؤتمرات والاتفاقيات الدولية , رسمت من خلالها هدف معين ألا وهو تحقيق توازن بيئى من خلال القضاء على المشاكل البيئية (وافى حاجه , 10 ـ ب). وبالنظر إلى الإنسان نجد أنه يحاول منذ أن وجد على الأرض أن بستخل موارد بيئته لإشباع حاجاته الأساسية ولهذا نجد دائماً علاقة ديناميكية تحكمها طبيعة البيئة وقدرات المجتمع وأفراده , كما أن الاهتمام بالبيئة يقترن بالاهتمام بالفعل الانسانى والمتغيرات التى تؤثز فى توجيه هذا الفعل توجيهاً يسهم فى أن يهتم الانسان ببيئته ويحافظ عليها ويحميها ويحمى نفسه من المخاطر ، ففى جميع الأحوال يجب على الإنسان أن يتعامل مع البيئة من أجل تحقيق الرفاهيه والتمتع بما تقدمه من موارد دون إهدار للتوازن البيئى ومنع التلوث لتحقيق ما يهدف اليه من تتمية وتطور وتقدم (يوزغاية باية , . . r). وهكذا فإن للبيئة إنعكاسات على صحة الإنسان الثئ الذى جعل الاهتمام بالبيئة ينزايد وجعل إثراك كل شرائح المجتمع وخاصة المرأة باعتبارها عنصراً فعالاً فى تتمية المجتمع ضرورة من أجل النهوض بالبيئة وتحسينها ، فالمرأة هى ربة الأسرة والمسئولة الأولى عن نوعية مستهلكات أسرتها من الخدمات والسلع كالأغذية أو الملابس أو الأدوات أو موارد

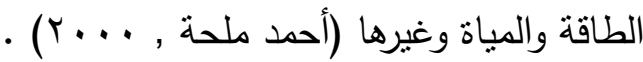


كما أن الأبناء أيضا هم الثروة الحقيقية لأى مجتمع من المجتمعات إذا احسن إستغلاله

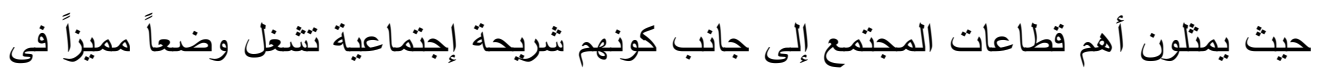

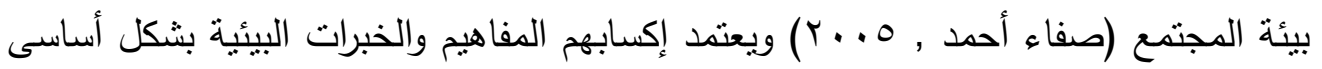

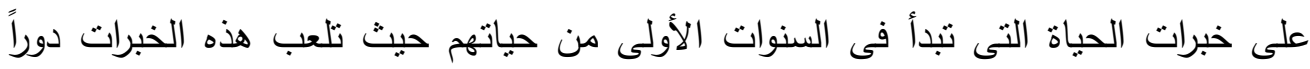
مهماً وحاسماً فى تتكيل أنماط ونماذج وقيم وإتجاهات الفرد البيئية طوال حياته كما أنها تكون لئن لديه الوعى البيئى وإتجاهات ومشاركات بيئية إيجابية كما أنها تسهم فى تكوين وبناء شخصيته

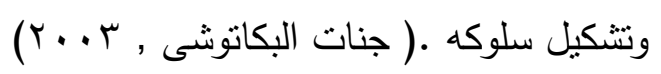

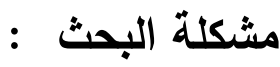

إن التعامل مع المشكلات البيئية يجب أن يكون على كافة المستويات لوضع سياسة

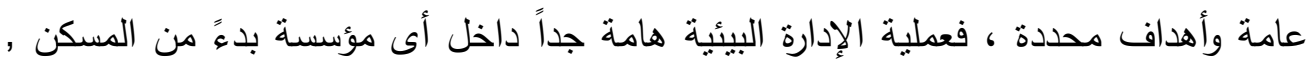

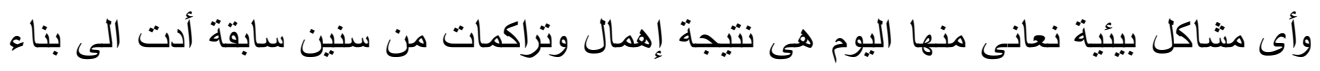

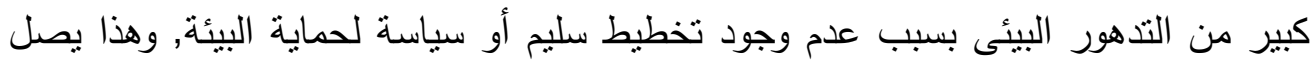
بنا إلى ضرورة تحديد أهداف واضحة للسياسات البيئية , وعلى الرغم من أن هذه السياسات

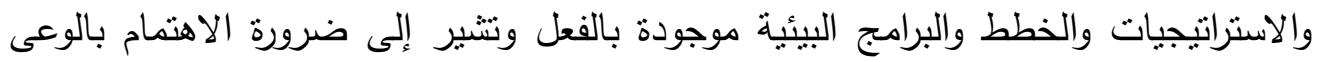

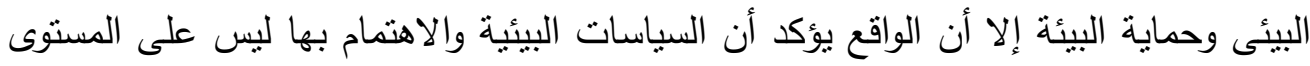

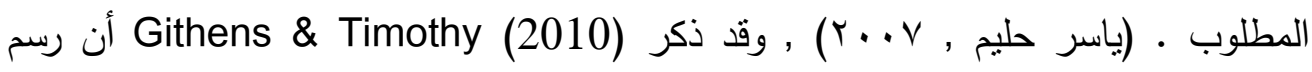
السياسات البيئية حق مطلق لكل مجتمع وأن هناك تفاعلاً مستمراً بين البيئة والتنمية الإجتماعية والاقتصادية .

وقد أقرت وفاء الصفتى (Y. . . F) مجموعة من السباسات لإدارة جودة البيئة المنزلية

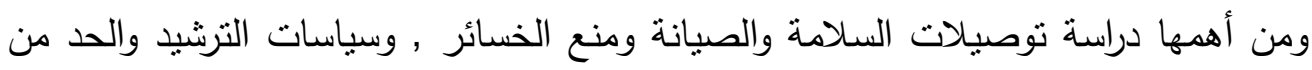
الإسراف فى استخدام الموارد الطبيعية , والتى يجب الالتزام بها عند التخطيط والتففذ والتقييم 
لأى عمل يقوم به أفراد الأسرة للحفاظ على الموارد الأسرية والانتفاع بها لأقصى درجة ممكنة فى ظل احتياجات الأسرة ودخلها والظروف البيئية السائدة . كما وضع (1990) Szckely توضيح أولى لمعنى السياسات البيئية بأنها مجموعة الأهداف والاجراءات التى تنتاول تنظيم العلاقة المتبادلة بين المجتمع وعناصر البيئة الطبيعية وتتثمل فى نطاقها كل مايتعلق بالحفاظ على البيئة وتحسين نوعيتها ومايتطلبه ذلك من

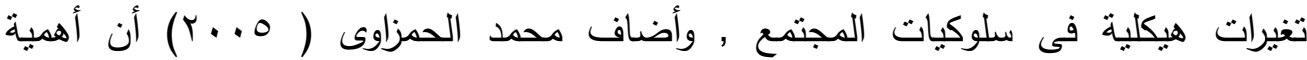
السياسات البيئية تتحدد فى كونها تجنب أفراد الأسرة الوقوع فى أخطاء تتجم عن العشوائية والارتجال والأهمال , كما يتضخ أهميتها فى تحقيق التتسيق والتكامل بين مشكلات البيئة

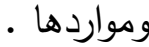

فالسياسات البيئية تعطى صورة واضحة ودقبقة عن مدى التزام الأسرة بكافة التشريعات البيئية والإلهية والحد من الإسراف وتقليل التلوث والحد من المخاطر البيئية مع توضيح طبيعة

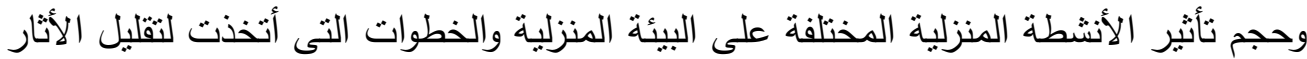
السلبية وتعظيم الأثار الإيجابية تجاه حماية البيئة , وتللك السياسات يجب البنه أن تكون معلنة لجميع أفراد الأسرة مع ضرورة الالتزام بالتحسين المستمر للأداء البيئى لجميع أفراد الأسرة

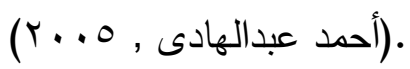

وقد أكدت وفاء الصفتى (Y. . . ع) على أهمية الالتزام بالتطوير والتحسين المستمر فى جميع مراحل الأعمال والأنشطة التى يقوم بها جميع أفراد الأسرة بهدف ترشيد إستخدام الموارد بهرب وضبط الملوثات والتحكم فى النفايات والحد من المخاطر , وترشيد استهلاك المياه والطاقة والخدمات ونشر السياسة البيئية وتوعية أفراد الأسرة بها ومراجعتها بصفة دائمة . في حين أكد أحمد دسوقى (l (†) على ضرورة الاستثمار الأمثل للموارد البيئية الدائمة والاستغلال الرشيد لمواردها المتجدة وغير المتجدة وصيانتها مما قد يهدها من أخطار وذلك من خلال مجموعة من الممارسات والسياسات ، كما أنثارت عائشة سعيد 
عدد خاص من مجلة "بحوث في العلوم والقنون النوعيه" العيه

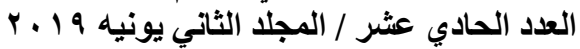

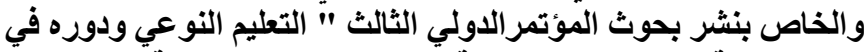

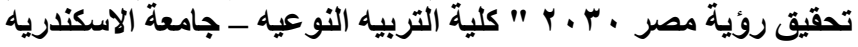

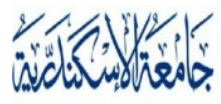

ALEXANDRIA

U N I V E R S I T Y

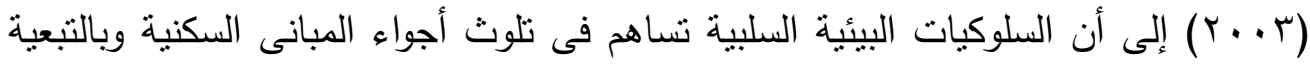
تعرض سكانها الى العديد من المشكلات ويرجع ذللك الى ما تمارسه المرأة من سلوكيات بيئية وممارسات إدارية غير واعية كالإتجاه نحو الإستهلاك المفرط والتعامل الخاطئ غير الأمن لئن مع مكونات البيئة مما ينعكس على صحة أفراد الأسرة . فلا شك أن للمرأة دور كبير ومؤثر فى المحافظة على البيئة وذلك عن طريق حسن البن

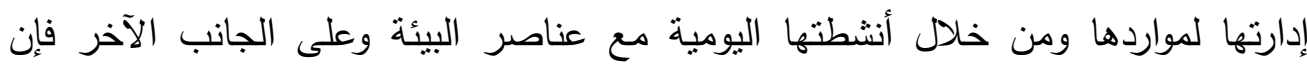

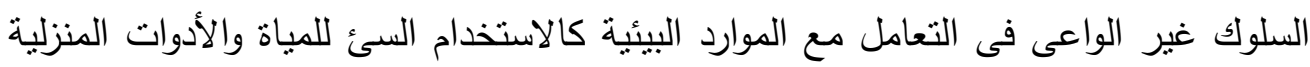
وسوء التصرف فى المخلفات المنزلية بالاضافة الى استخدام المصادر التقليدية فى انتاج الطاقة كل هذا يؤثر بصورة مباشرة أو غبر مباشرة على تلوث البيئة (أمنحتب ميخائيل, $\cdot(r+1)$

وقد اثنارت العديد من الدراسات الى دور ربة الأسرة فى نتكيل وتتظيم السياسات

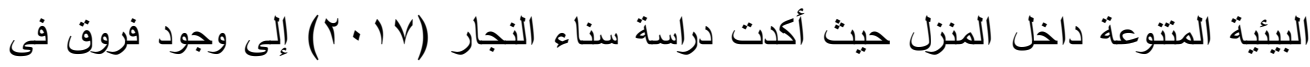
السياسات الإستهلاكية التى تتبعها ربة الأسرة تبعاً للمتغيرات الديموجرافية , كما أكدت دراسة التهاء

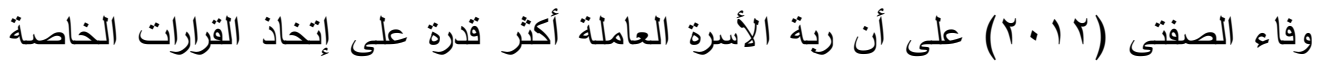

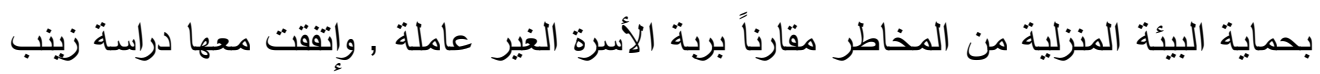
يوسف (10 ب ب) فى تفوق العاملات على غير العاملات فى الممارسات الإستهلاكية الرشيده

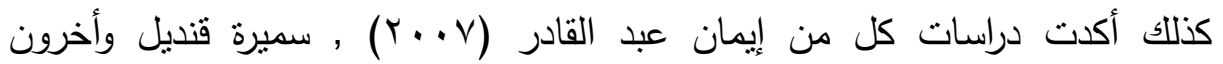

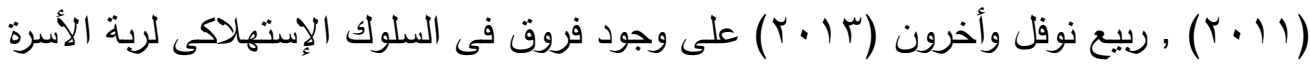

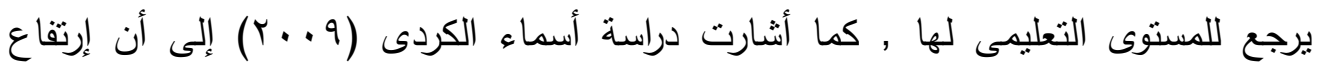
مستوى تعليم المرأة يزيد من إتجاهاتها الإيجابية نحو صبانة وإصلاح الأجهزة المنزلية والمرافق

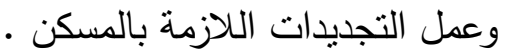


وبالنظر إلى مصادر تكوين الخبرات والمعارف البيئية لدى الأبناء نجد أنها متعدده

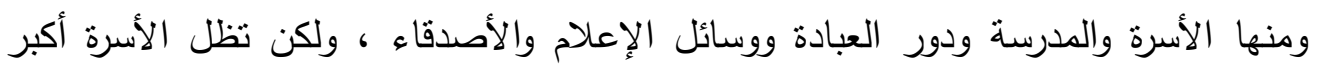

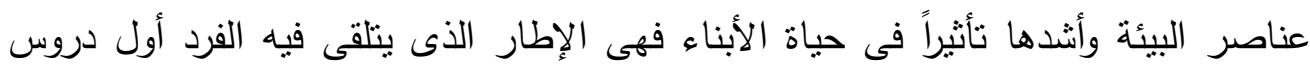
الحياة وتعد أهم عناصر التتشئة الإجتماعية لدورها الفعال في إكساب الإباء الأبناء الخبرات

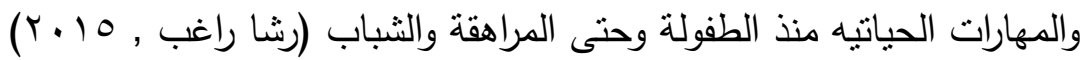
فالخبرات البيئية فى الطفولة تكتسب أهمية خاصة فى كونها عاملاً حاسماً فى تكوين شخصية الفرد حيث يرى علماء النفس أن السنين الأولى من عمر الفرد تلعب دوراً هاماً خلال

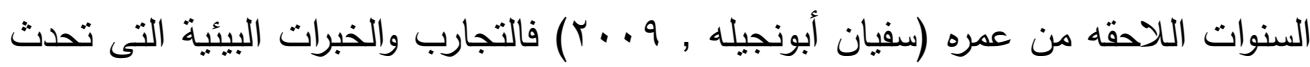

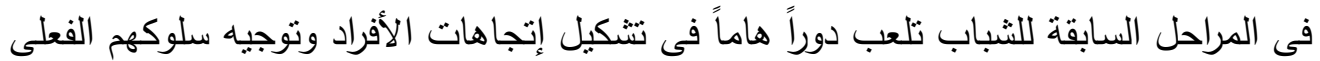
فيما بعد (مهيب جودة , • • (ץ) •

وتؤثر الخبرات البيئية المكتسبة ليس فقط على السلوك الإجتماعى للأبناء ولكن أيضاً على إعدادهم للحياة المستقبلية وتزويدهم بالمفاهيم والمهارات المرنبطة بالتخطبط للمستقبل

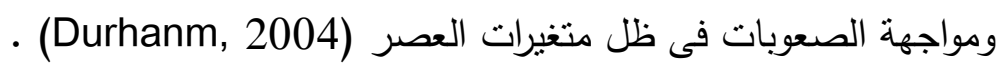

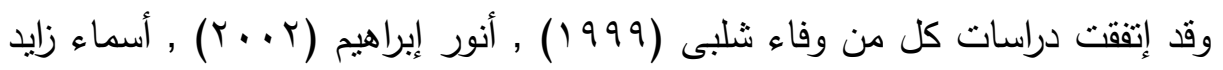

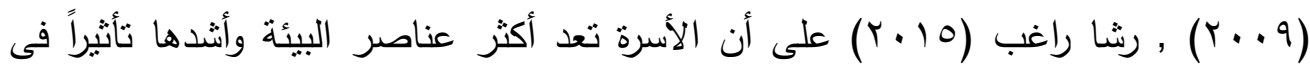
الأبناء ممثلة فى الأم فهى مصدر إكتساب الأبناء للقيم والاتجاهات والمهارات والخبات الخبرات

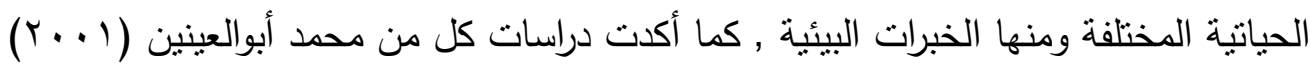

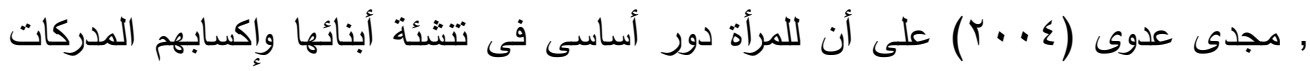
والاتجاهات والقيم الإيجابية نحو البيئة ونظافتها وذللك من خلال توجيههم أو عن طريق القدوة

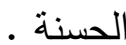
فى حين أثنارت بعض الدراسات لتأثير العوامل الديمجرافية على الوعى والخبرات

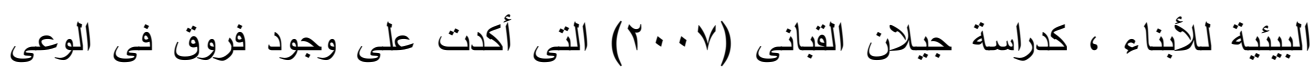


البيئى بين الذكور والإناث لصالح الإناث , وأختلفت معها هبه شعيب (• • ( ) فى عدم

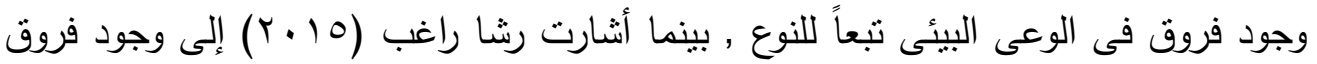

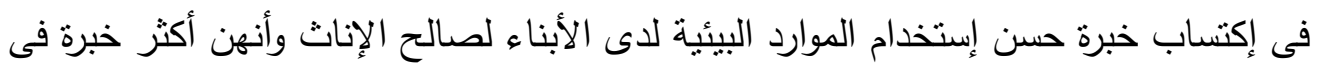
كيفية العناية والاستخدام الجيد للموارد البيئية من ماء وكهرباء وغاز وخدمات متاحة بخلاف

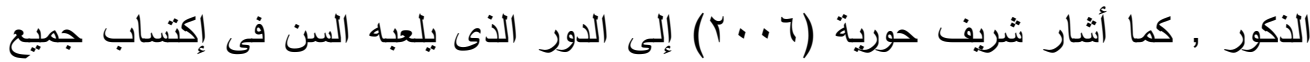

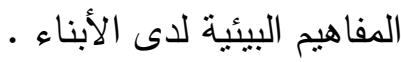

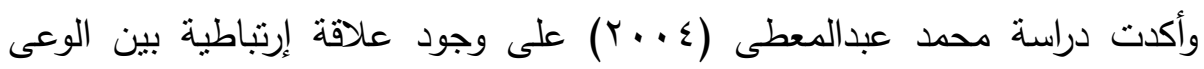

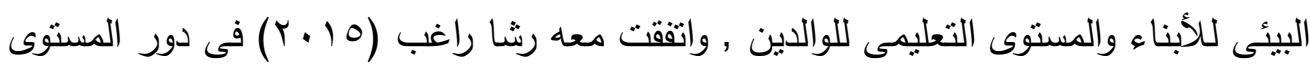

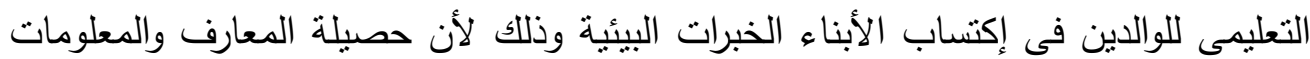

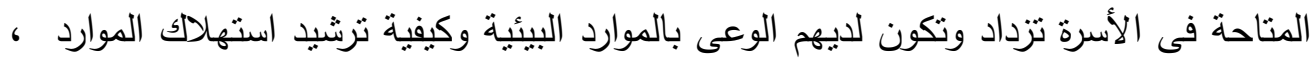
كما أكدت أيضا على أثر مستوى الدخل فى ذللك , وإختلفت معها جيلان القبانى (Y. . . (Y)

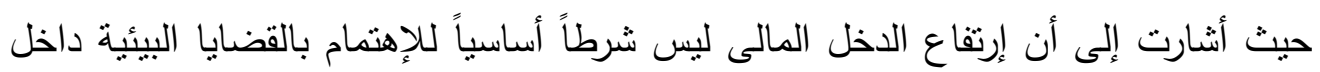
الأسرة . وهنا تبرز أهمية التنشئة الإجتماعية والتى تبدأ من الأسرة ونهاية بكل مايحيط بالأبناء

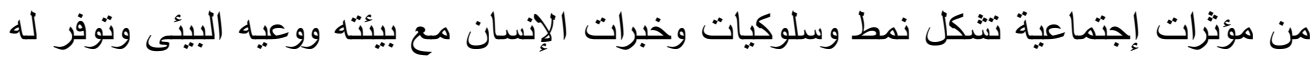
القدوة السوية فى التعامل البيئى بحيث لا يعتاد الإبن السلوكيات السلبية المضادة للتعامل الاجتماعى مع البيئة ويتألف ويتعايش معها ومن خلالها (نظيمة سرحان , 0. . ب). وحيث أن تحقيق التتمية المستدامه يتطلب تغيير وتعديل فى الوعى والأنماط السلوكية

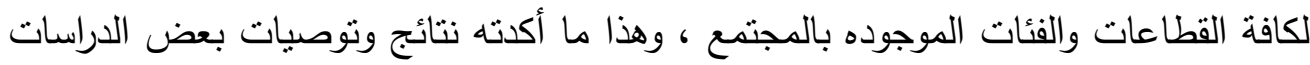
، كدراسة Choi (2006) التى أثنارت إلى أنه لتوسيع البحث فى التتمية المستدامة يجب

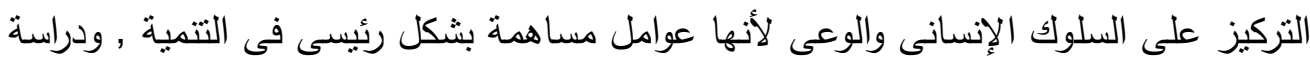
Schmdit (2007) التى أكدت على وجود علاقة إرتباطية موجبة بين الإتجاهات والسلوك فئل 
مع البيئة , ودراسة أيمن عكرش وسحر نويصر (10) التى أوصت بضرورة الاهتمام بالوعى بترشيد الطاقة وإدارة المنزل كعامل ممهد لزيادة مستوى الوعى بممارسات التتمية

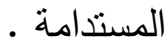

وبما أن ربة الأسرة بما تملكه من إمكانات تعد بمثابة القوة القادرة على إحداث التتمية والإبتكار والتحديات والتقام كما تعتبر أحد الدعائم الأساسية فى التتمية الإقتصادية وتحريك الإن عجلات النمو (وفاء شلبى , منار خضر , r. .ب) , وحيث أن دراسة السلوكيات والسياسات المنزلية تعد من المؤشرات الأساسية التى تكشف مسيرة التتمية الاقتصادية مما يتطلب الإلمام بالعوامل المؤثرة فيه بغية دراستها وتحليلها (عدنان غانم , فريد الجاعونى , • • ب) ، ونظرا لآن تحقيق متطلبات التتمية المستدامة يتطلب التركيز على دور المرأة الأم فى عملية التتمية المستذامة بإعتبارها نصف المجتمع وهى لصيقة بالبيئة ومحور التتمية ومصدر التنشئة

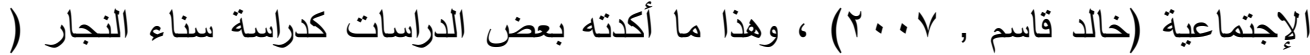

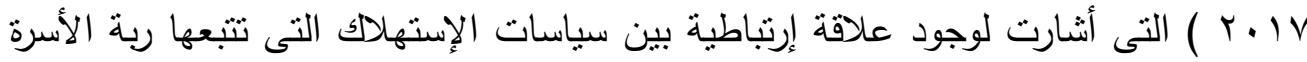

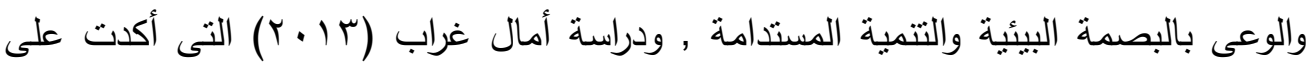
ضرورة تدعيم دور المرأة فى تحقيق الإستدامة وبالتالى توفير مصادر التتمية المستدامة من خلال الاتجاه الى إقتصاد بيئى ـ نبعت فكرة البحث الحالى فى محاولة من الباحثتان للتعرف على طبيعة سياسات الإلتزام البيئى لرية الأسرة داخل منزلها والمتمثلة فى تقنينها وترشيدها لعلية الاستهلاك والاتجاه نحو السلوك الرشيد , ومدى مراعتها لعناصر السلامة البيئية وتحجيم أنشطة التلوث وإلحفاظ على صحة البيئة , وممارستها نحو إعادة تدوير المخلفات المنزلية وتعظيم الفائدة من الموارد , وتبنيها لسياسة الإصلاح والصيانة المنزلية والحفاظ على ممتلكاتها , وإنعكاس إتباعها لتلك السياسات على مايكتسبه الأبناء من خبرات بيئية فى ضوء تحديات التنمية المستدامة تماشيا مع خطة التمية الثاملة التى تواجهها البلاد , وذلك من خلال الإجابة على التساؤلات التالية : 
ـ ما هى نوعية المرافق التى بها أعطال بالمسكن ولم تتمكن ربات الأسر عينة البحث

\section{من صيانتها ؟ أنما}

ـ ما هى مصادر التلوث والإزعاج الموجودة بالبيئة السكنية لربات الأسر عينة البحث ؟

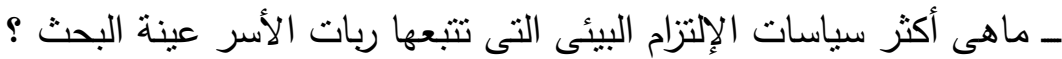

ـ ماهى أكثر الخبرات البيئية لدى الأبناء فى ضوء التتمبة المستدامه ؟ ـ ما هو مستوى سياسات الإلتزام البيئى لربات الأسر والخبرات البيئية للأبناء فى ضوه الاءه

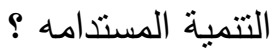

ـ هل هناك فروق فى سياسات الإلتزام البيئى بمحاورها لدى ربات الأسر عبنة البحث

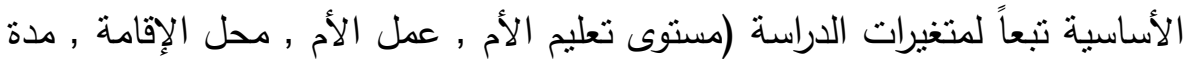

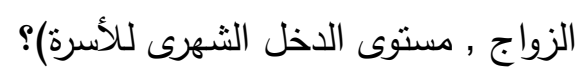

ـ هل هناك فروق فى الخبرات البيئية للأبناء فى ضوء لهون التتمية المستدامه تبعاً لمتغيرات الدراسة (الجنس , الترتيب بين الأخوة , محل الإقامة , مستوى تعليم الأم )؟ ـ هل توجد علاقة إرتباطية بين سياسات الإلتزام البيئى لربة الأسرة والخبرات البيئية لكلأبناء فى ضوء التتمية المستدامه ؟

ـ هل تختلف نسبة مشاركة المتغيرات المستقله فى تفسير نسبة التباين فى المتغير التابع (الخبرات البيئية للأبناء فى ضوء التتمية المستدامه) تبعاً لأوزان معاملات

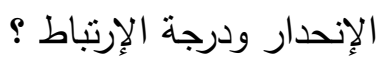

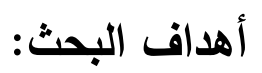

يهدف البحث الحالى بصفة أساسية إلى دراسـة إنعكاس سياسـات الإلنزام البيئى لربـة

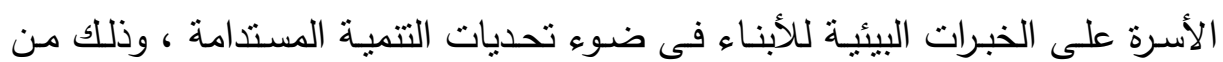

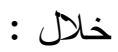


عدد خاص من مجلة "بحوث في العلوم والقنون النوعيه" / التوبه

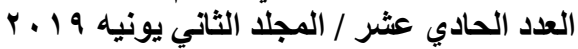

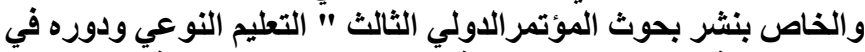

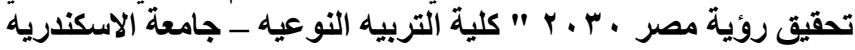

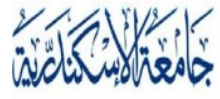

ALEXANDRIA

U N I V E R S I T Y

Alexu Press

viple

1 ـ الكثف عن نوعية المرافق الموجود بها أعطال بالمسكن ولم تتمكن ربات الاسر

من صيانتها.

r ـ الكثف عن مصادر التلوث والازعاج الموجوده بالبيئة السكنية لدى ربات الأسر . ץ ـ تحديد أكثر سباسات الالتزام البيئى المتبعة لدى ربات الأسر عينة البحث.

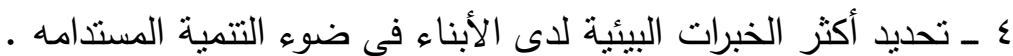

ـ ـ التعرف على مستوى سياسـات الالتزام البيئى لدى ربـات الأسر والخبرات البيئية للأبناء فى ضوء التتمية المستدامه.

7 ــ تحديـد الفـروق بـين سياسـات الالتزام البيائى لـدى ربـات الأسـر عينـة البحـث

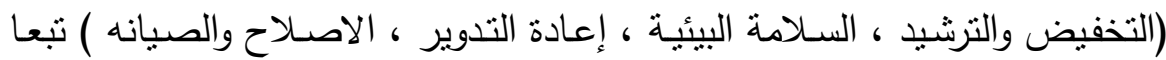

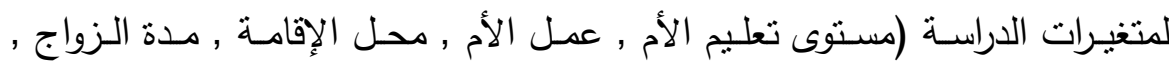

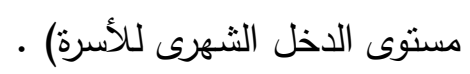

V - دراسـة الفروق بين مجالات الخبرات البيئية للإبنـاء فى ضوء التتميـة المستدامه

(الاستفادة من الطاقة المتجددة ، إدارة الموارد البيئية ، مواجهة المشكلات البيئية )

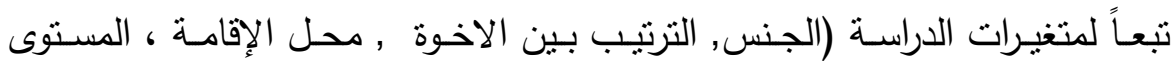

$$
\text { التعليمى للأم). }
$$

ـ ـ الكثف عن طبيعة العلاقة بين سياسات الالتزام البيئى لدى ربات الأسر ومجالات

الخبرات البيئية للإِبناء فى ضوء التتمية المستدامه.

9 ـ التعرف على نسبة مشـاركة المتغيرات المستقله ( سياسـات الالتزام الييئى لربـة

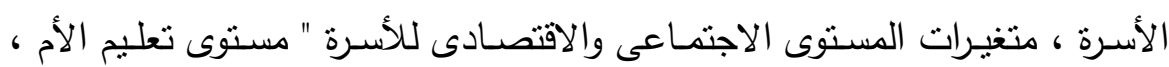

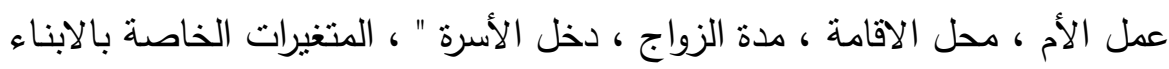

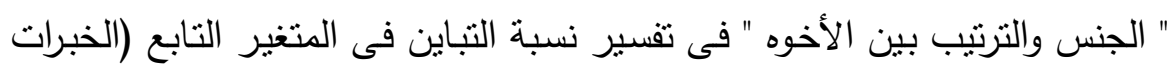


البيئية للأبناء فى ضوء التتمية المستدامه) تبعاً لأوزان معاملات الإنحدار ودرجة

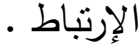

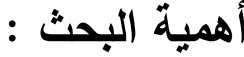

\section{يكتسب هذا البحث أهميته من حيث :}

1 ـ تتاوله لسياسات الالتزام البيئى لربة الأسرة داخل بيئتها السكنية كمدخل لتوضيح دورها فى حل المشكلات البيئية المتزايده فى ظل الاهتمام العالمى والمحلى بالقضايا البيئية وإظهاراً لدورها باعتبارها عنصراً فاعلاً فى تتمية المجتمع وعلى صلة وثثقة بالبيئة تؤثر فيها وتتأثر بها

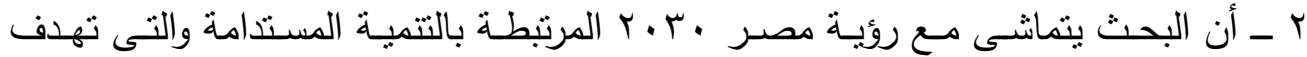
لتحسين جوده حياة المواطنين فى الوقت الحاضر بما لا يُخل بحقوق وحصة الأجيال القادمة

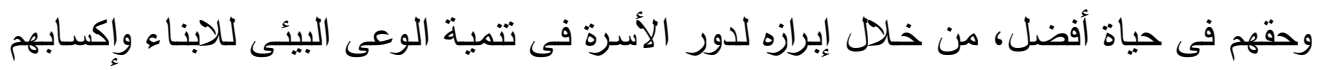
الخبرات البيئية بما يحقق متطلبات النتمية المستدامه .

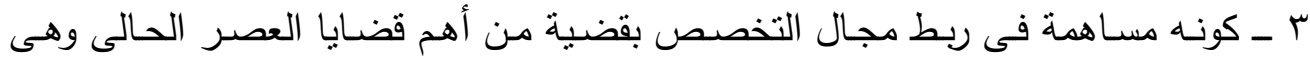
قضـية التتميـة المستـامة والتـى تعتبـر حديث الاوسـاط الاقتصـادية والسياسـية والاجتماعيـة والاعلاميـة , والإثـارة الى ضرورة التركيز على السلوك الإنسانى وتتمية الوعى لأنها عوامل مساهمة بشكل رئيسى فى دفع عملية التتمية . ع - يسـهم البحث في التوصل إلى استيراتيجيه مقترحسه لتحسين الاداء البيئى الأسـرى بمـا بساهم فى تحقيق منطلبات التتمية المستدامة للمجتمع •

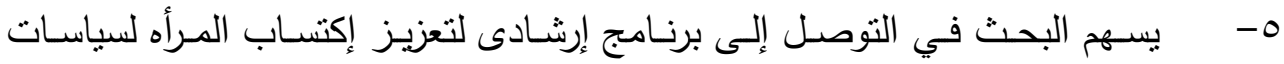

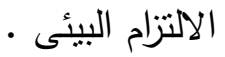


عدد خاص من مجلة "بحوث في العلوم والفنون النوعيه"

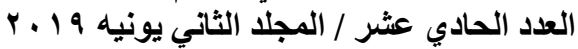

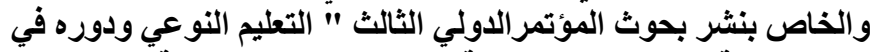

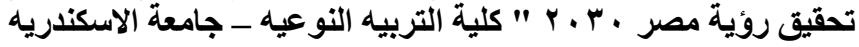

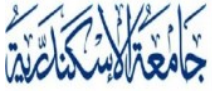

ALEXANDRIA

U N I VER S I T Y

Alexu Press

(i)

\section{فروض البحث:}

1 ـ توجد فروق ذات دلالة إحصائية فى سياسات الإلتزام البيئى لربات الأسر عينة البحث

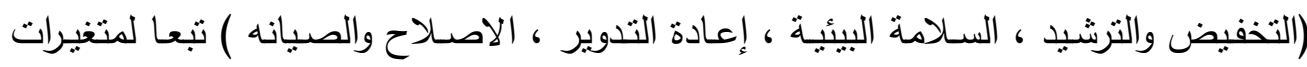

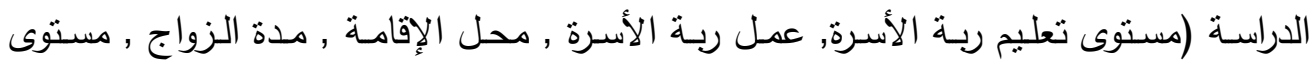

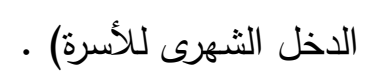
r ـ توجد فروق ذات دلالمة إحصائية فى مجالات الخبرات البيئية للأبناء في ضوء التتمية المستدامه (الاستفادة من الطاقة المتجددة ، إدارة الموارد البيئية ، مواجهة المشكلات البيئية )

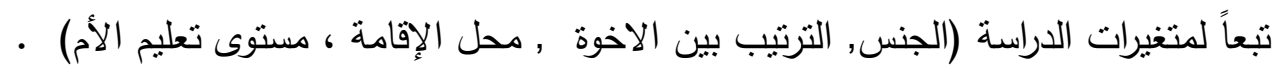

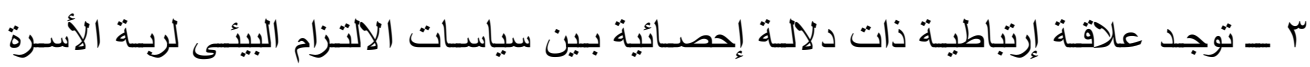

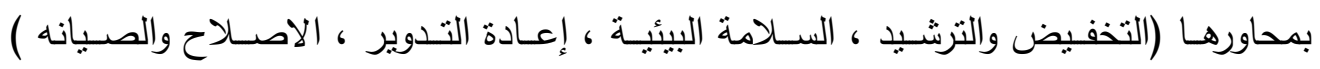

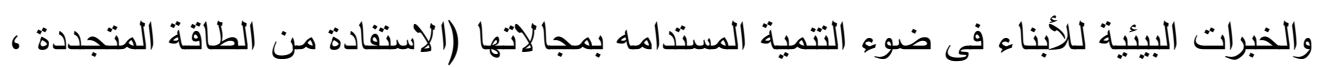
إدارة الموارد البيئية ، مواجهة المشكلات البيئية ).

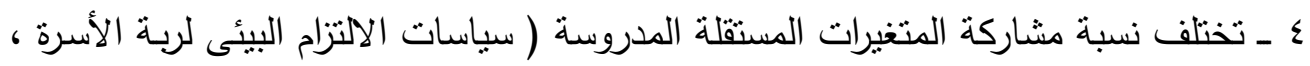

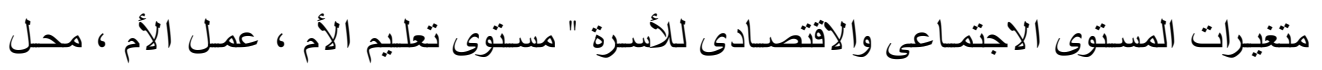

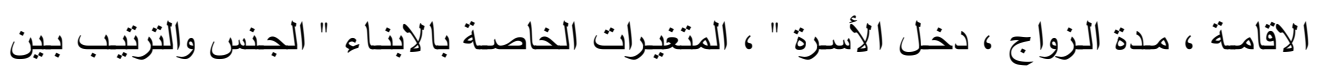

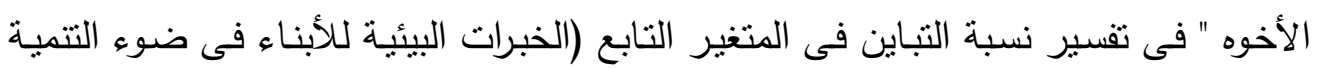

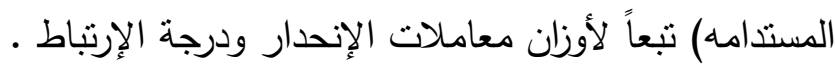

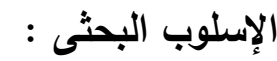
أولاً: منهج البحث :

يتبع هذا البحث المنهج الوصفي التحليلي وهو الذي يعتمد على دراسة الظاهرة كما

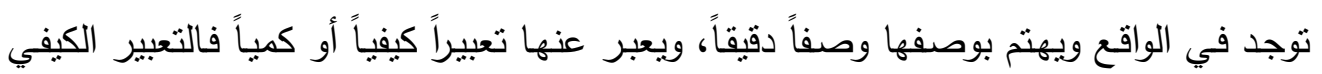

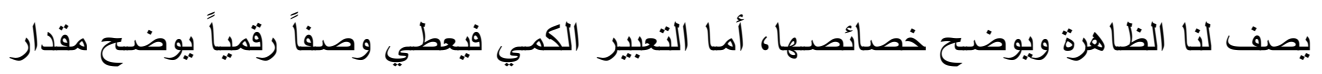


هذه الظـاهرة أو حجهـا ودرجـة ارتباطهـا مــع الظـواهر الأخـرى (ذوقـان عبيدات وآخـرون، $\cdot(r+1)$

\section{ثانياً: مصطلحات البحث :}

Policy: السياسة

هي تفكير منظم يوجه سلوك وتصرفات الفرد أو الجماعة ، وهي مجموعة من القرارات والقواعد المتتاسقة والمترابطة فيما بينها، والتي تستهدف تحقيق أهداف معينه مقصودة

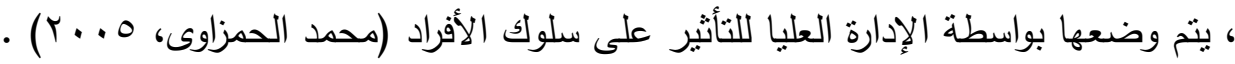

Environmental Policy : السياسات البيئية

هى مجمل الاجراءات الضرورية للححافظة على البيئة وتحسين نوعيتها وذلك بهدف تجنب الاضرار الحالية والعمل على إزالتها وجعل الأخطار التىى تهدد الانسان عند أدنى لهى

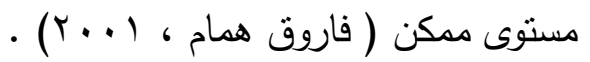

وعرفها كل من نجم العزاوى ، عبد اله النقار ( V.... بانها بيان من قبل المنظمة لاهدافها ومبادئها المتعلقة بادائها البيئى الاجمالى الذى يقدم إطار عمل ووضع الأهداف والغايات البيئية للمنظمة .

Environmental Compliance Policies: سياسات الالتزام البيئس واليهى عرفتها وفاء الصفتى ( Y. . . بأنها مجمل الإجراءات والقواعد والمبادئ الواجب الالتزام بها للحد من الاسراف فى استخدام الموارد الطبيعية ، والحد من تلوث البيئة المنزلية ، والحد من المخاطر المنزلية للمحافظة على جودة البيئة المنزلية وتحسينها بشكل مستمر .

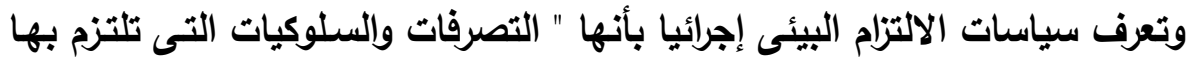

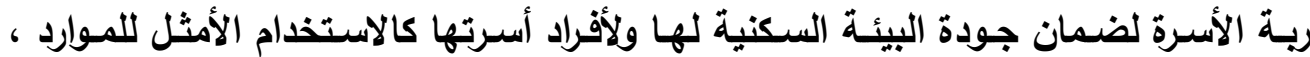
الحفـاظ على سـلامة البيئة الداخليـة للمسكن ، إعادة تدوير المنتجات المتاحـة فضـلا عن 
إجـراءات السـلامة والصيانه الدوريـة نحـو معالجـة إى أضـرار بمحتويـات المسكن " . وقــ قسمت الباحثتان سياسات الالتزام البيئى في هذه الاراسة إلى أريعة سياسات: 1 - سياسة التخفيض والترشيد:

وتعنى الاستخدام الأمثل للموارد من خلال خفض الاسراف والاستهلاك الزائد فى استعمال الموارد (مياه ، غذاء ، طاقة) وإتباع السلوك السوى من التوسط والاعتدال فى استخدامها للحد المسموح به .

\section{r - بياسة السلامة البيئية :}

وتعنى كافة الأنشطة والاجراءات التى تتخذها ربة الأسرة للحفاظ على البيئة الداخلية للمنزل نظيفة بقدر الإمكان وخالية من أى ملوثات من خلال تقليل مصادر التلوث (المائي , الغذائى , الهوائي، السمعى ، الاشعاعى) ، وحرصها على إستخدام منتجات صديقة للبيئة .

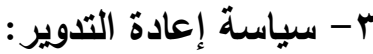

ويقصد بها إستغلال ربة الأسرة لما لديها من بعض الموارد (الغذاء , الملابس , المستهلكات المنزلية) سواء كانت تلك الموارد مستهلكة جزئياً أو كلياً وتعظيم المنفعة منها من لهن خلال الاستفادة منها وإعادة تدويرها فى تصنيع منتجات جديدة تعود بالنفع عليها وعلى أفراد أسرتها خال

\section{؛ - سياسة الاصلاح والصيانه :}

وتعنى اجرءات الصيانة والسلامة الدورية التى تقوم بها ربة الأسرة نحو معالجة أى لى أضرار أو تلفيات ناتجة عن أنشطة أفراد الأسرة فى التعامل مع محتويات المسكن بما تشمله لهـه من أجهزة ومرافق وتجهيزات بما يضمن جودة وأمان جميع الخامات والمواد المتداولة بالمنزل . 


\section{Experience : الخبرة}

مصطلح يتضمن المعرفة أو المهارة أو القدرة على الملاحظة ، وعادة ما يكتسب

الإنساف الخبرة من خلال المشاركة في عمل معين أو حدث معين ، و غالبا ما يؤدي تكرار

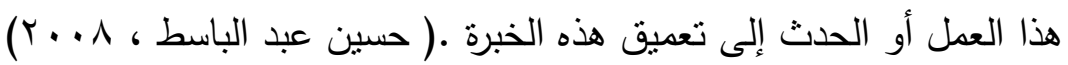

كذللك تعرف الخبرة بأنها موقف من المواقف يعيشه الفرد مع آخرين فيتأثر

به ويؤثر فيه وهو يتعلم نتائج هذا الموقف حيث تصبح هذه النتائج جزءاً من سلوكه سواءاً

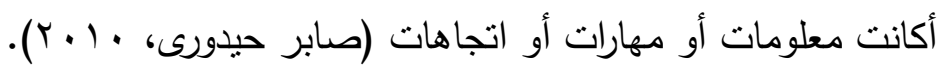

The environment : البيئة

هى العوامل الخارجية التي بستجيب لها الفرد أو المجتمع بأسره استجابة فعلية احتمالية كالعو امل الجغرافية والمناخية من سطح ونبات وموجودات وحرارة ورطوبه

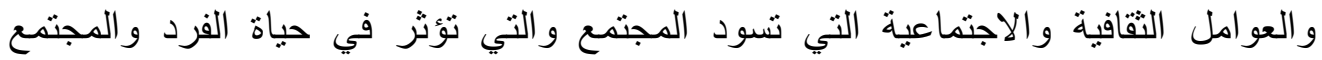

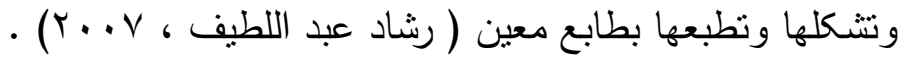

\section{Environmental Experiences : الخبرات البيئية}

تعرف بأنها اكنساب الفرد للمكونات المعرفية والانفعالية والسلوكية من خلال

تفاعله المستمر مع بيئته والتي تسهم في تتكيل سلوك جيد يجعل الفرد قادراً على التفاعل

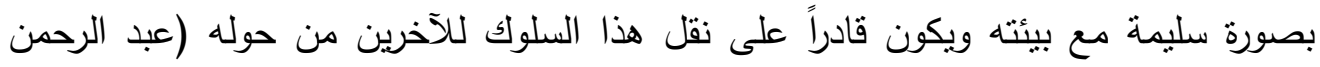

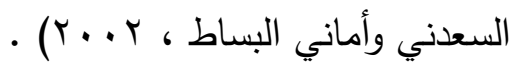
وعرفتها فاطمة خليفة ( ع . . ب) بأنها العملية المنظمة لتكوين القيم والاتجاهات والمهارات

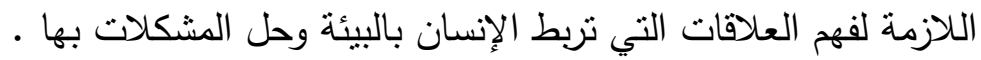
بينما ترى باسمة حلاوة (ج . T) أن الخبرات البيئية هي المواقف التي تعلمها الفرد

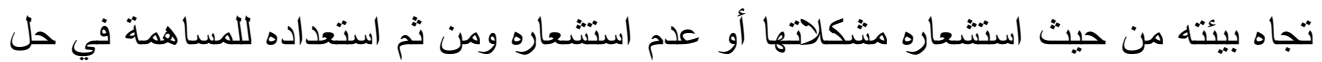


هذه المشكلات وتطوير ظروف البيئة نحو الأفضل أو عدم استعداده وكذلك موقفه من استغلال الموارد الطبيعية في هذه البيئة استغلالاً راشداً أو جائراً.

وتعرف الخبرات البيئة فى ضوء التمية المستدامة إجرائيا بانها " جملة المعارف

والمفاهيم والمهارات البيئية التى إكتسبها الأبناء من الأسرة ومن خلال تفاعلاتهم مع مكونات البيئة المحيطة بهم مما إنعكس على إدراكهم ووعيهم باهمية استخدام مصادر الطاقة المتجدده وغرس لايهم سلوكيات إيجابية نحو الحماية والمحافظة على الموارد البيئية والمشاركة الفعالة فى حل مشكلات البيئة من أجل توفير بيئة مستدامه لهم وللأجيال القادمة

\section{sustainable development : التنمية المستدامة}

تعنى الاستخدام الأمتل لجميع الموارد المتاحة سواء البشرية أو المادية والمعنوية وغيرها للمستقبل البعيد مع التركيز على حياه أفضل ذات قيمة عالية للأجبال القادمة في الحاضر الاضر

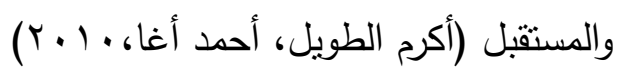

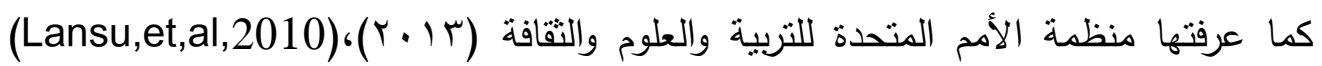
بأنها تلك التتمية التي تلبى احتياجات الجيل الحاضر دون التضحية أو الإضرار بقدرة الأجيال القادمة على تلبية احتياجاتها ـ ويتبنى البحث الحالى مفهوم التنمية المستدامة بأنها التنمية التي تعمل على التوازن بين تلبية احتياجات ومتطلبات الأفراد من الموارد في الوقت الحاضر وتلبية احتياجات الأجيال القادمة من هذه الموارد مستقبلاً وتثتتمل على بعدين أساسيين هما البعد الاقتصادي والبعد

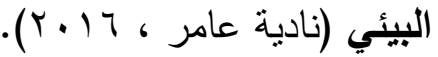

$$
\begin{aligned}
& \text { الأبناء: children }
\end{aligned}
$$

يقصد بالأبناء في هذا البحث البنين والبنات فى مرحلة المراهقة والتى تتراوح أعمارهم بين

11 1 1 سنه ومن مستويات اجتماعية واقتصادية مختلفة وممن يقيمون في الريف والحضر . 
الحدود الجغرافيه للبحث: يتحدد النطاق الجغرافى فى محافظات القاهرة والمنوفية (حضر وريف) , وقد تم التطبيق على بعض الطلاب وأمهاتهم بمدرستى المعادى التجريبة الرسمية للغات ، الجيل الجديد للغات بمنطقة المعادى بمحافظة القاهرة ، ومدرستى قويسنا الرسمية

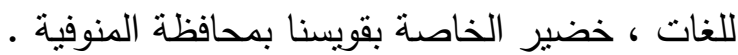
الحدود البشربه للبحث : تكونت عينة البحث من مجموعتين :

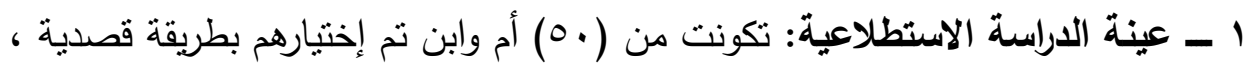

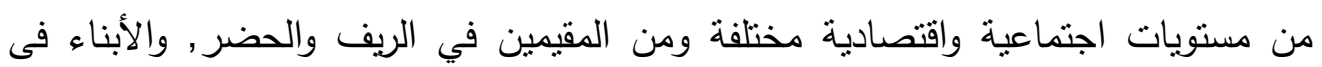
المرحلة العمرية 10:10 وذلك لتقنين أدوات الدراسة المتمثلة فى (استمارة البيانات العامة-

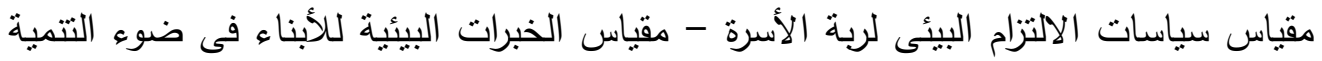

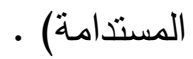

r ـ عينة الاراسة الأساسية: تكونت من (ro أم أم وابن تم إختيارهن بطريقة عمدية قصدية

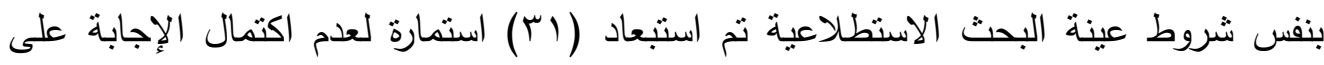
جميع عبارات المقياس وبذلك أصبحت عينة البحث الأساسية (Y) (Y) أم وابن .

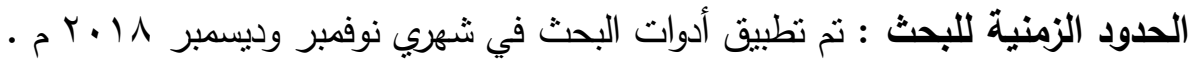
رابعاً : أدوات البحث (إعداد الباحثثان) 1- إستمارة البيانات العامة . r-مقياس سياسات الإلتزام البيئى لربة الأسرة .

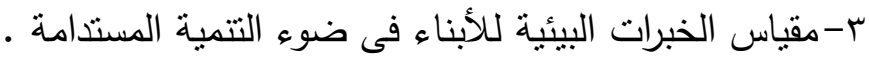




\section{ا 1 - إستمارة البيانات العامة :}

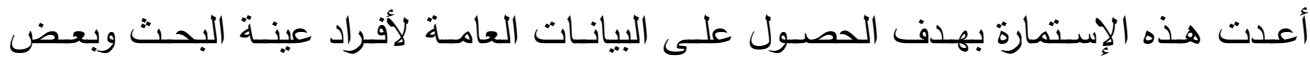

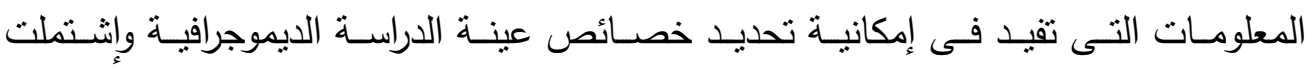

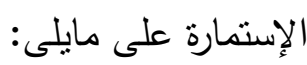

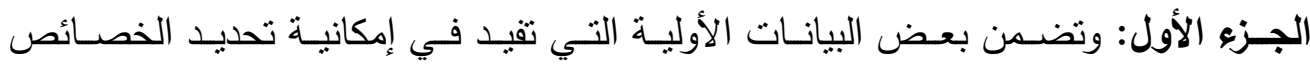

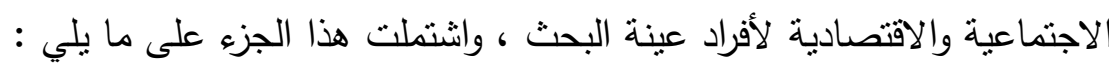
أ- بيانات خاصة بربات الأسر : (مدة الزواج , المستوى التعليمي للأم , الحالة الوظيفية للأم , محل الإقامة , الدخل الثهري للأسرة).

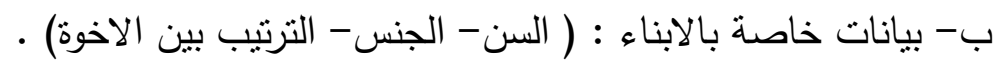

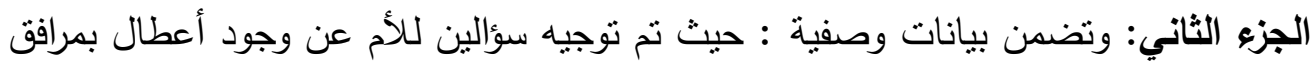
المسكن تحتاج صيانه دع تحديد تلالك المرافق ، ومدى وجود مصادر إزعاج وتلوث بالبيئة السكنية وتحديدها حال وجودها ، وسؤال للأبناء عن درجة المشاركة فى الأنشطة البيئية .

\section{r ـ مقياس سياسات الإلتزام البيئى لرية الأسرة :}

بعد الاطلاع على الدراسات السابقة المرتبطة بموضوع البحث تم إعدرة لعداد هذا المقياس فى ضوء المفهوم الإجرائى الوارد بالبحث بهدف التعرف علي سياسات الالتزام البيئى التى لتى

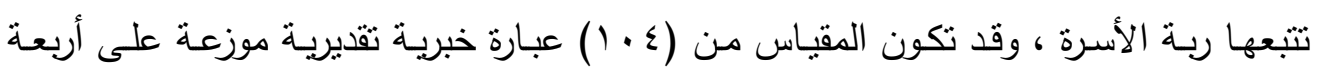

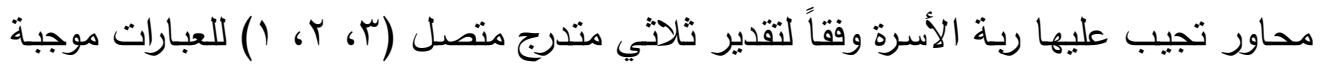

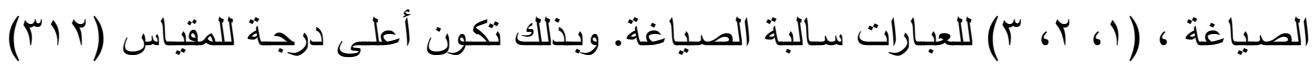

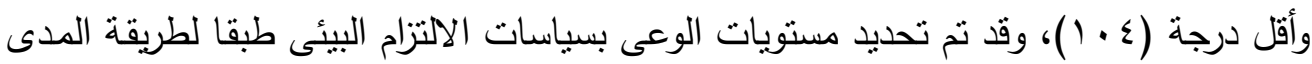
كالتالى :

$$
\text { المدى = أعلى درجة - أقل درجة = أ }
$$




$$
\text { طول الفئة = المدى }
$$

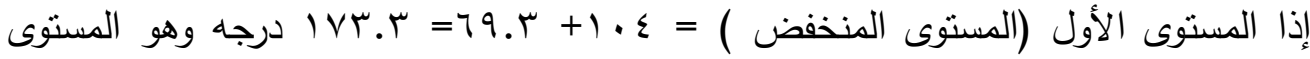

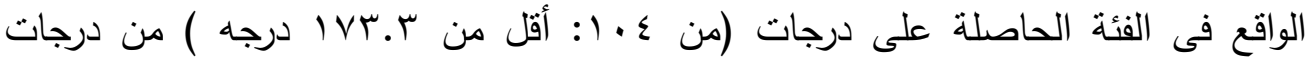

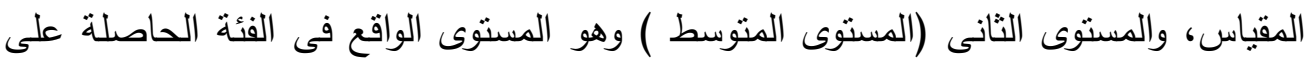

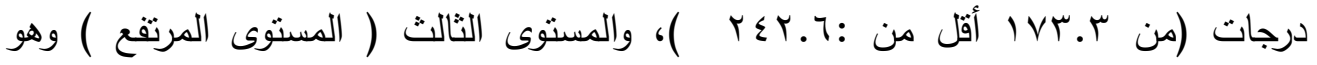

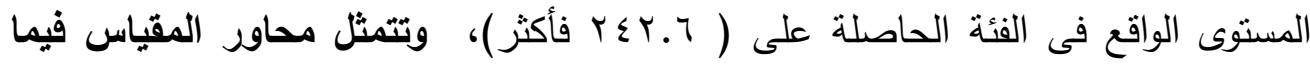

المحور الأول : سياسة التخفيض والترشيد: واشتمل هذا المحور علي (Yq) عبارة موزعة

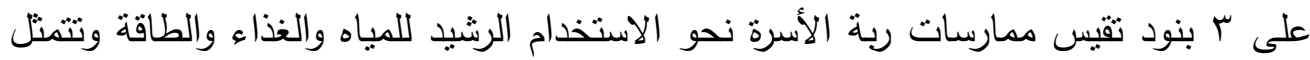
فى : أ- ترشيد استخدام المياه : تكون هذا البند من(9)عبارات خبرية؛ تقيس سلوكيات ربة الأسرة من حيث الحرص على عدم فتح الصنبور لآخره عند الاستخدام ، غلق الصنبور بعد

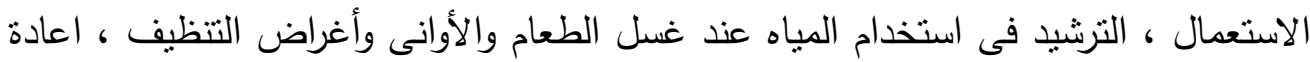
استخدام المياه المستخدمه فى نقع وغسل الملابس فى أغراض منزلية أخرى .

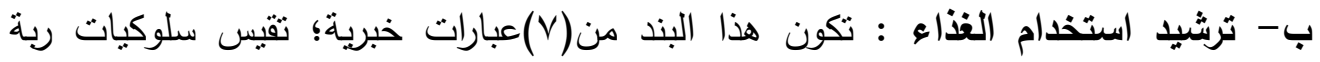

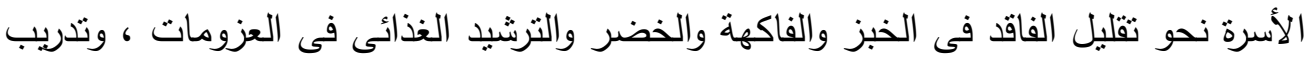

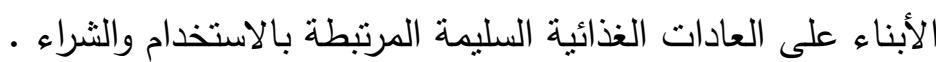
ج- ترشيد استخدام الطاقة : تكون هذا البند من(ب ( )عباره خبرية؛ تقيس سلوكيات ربة الأسرة

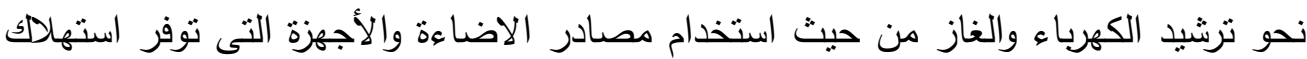
الكهرباء ، حرصها على فصل الاجهزة الكهربائية ونزع الفيشة فى حال عدم التشغيل ، الحرص على ضبط التوقيت الزمنى عند نشغيل الاجهزة والإضاءه، وغرس عادات الاستهلاك 
عدد خاص من مجلة "بحوث في العلوم والقنون النوعيه" العزيه

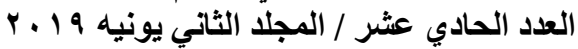

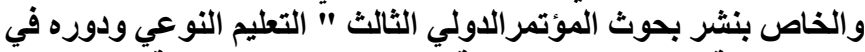

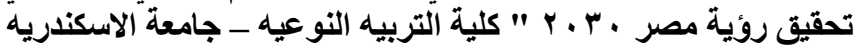

الرشيد للكهرباء والغاز لدى الابناء ، ، الطهى فى الأوانى البيركس واستخلال الفرن لطهى عدة أطعمة .

المحور الثانى : سياسة السلامة البيئية : واشتمل هذا المحور علي (rV) عبارة موزعة على بندين تقيس ممارسات ربة الأسرة نحو الحفاظ على البيئة الداخلية للمنزل نظيفة سواء من خلال تقليل مصادر التلوث و إستخدام منتجات صديقة للبيئة وتتمثل فى : أ- الحد من مصادر التلوث (المائي , الغذائى , الهوائي، السمعى ،الاشعاعى): تكون هذا البند من (Yq)عباره خبرية؛ تقيس سلوكيات ربة الأسرة نحو تقليل مصادر نلوث المياه كالحرص على معرفة نوعية البلاستيك التى لا نؤثز على سلامة المياه وتغطية وتتظيف الآوانى والزجاجات المستخدمه فى حفظ مياه الشرب ، وتجنب غلى المياه فى آنية الألومونيوم ، استخدام فلاتر لتتقية المياه ، فضلا عن تقليل مصادر التلوث الغذائى كتجنب إذابة الاطعمة المجمدة وإعادة تجميدها ، تتظيف الخضروات والفاكهة بالماء والخل وتجنب استخدام الاوانى التيفال بعد التقثير والاطباق الميلامين مع الطعام الساخن ، ومدى حرصها على تقليل التلوث الهوائى من حيث تجنب استخدام البخور والثى داخل المسكن ، والحرص على تتظيف المراوح وفلاتز المكيفات والسجاد وتجنب التدخين ، فضلا عن تقليل مصادر التلوث السمعى من حيث تجنب رفع صوت التليفزيون أو الراديو واستخدام مكبرات للصوت وسحب الاثاث واستخدام أرضيات ماصة للصوت وتقليل الضوضاء الناتجه من تشغيل الأجهزة ، كذلك حرص ربة الأسرة على تقليل مصادر التلوث الاشعاعى الناتج من استخدام أجهزة الكمبيوتز والتليفون المحمول والميكروبف . ب- استخدام منتجات صديقة للبيئة : تكون هذا البند من (^)عباراته خبرية؛ تقيس حرص ربة الأسرة على استخدام المنتجات الغير ملوثة للبيئة والاعتماد على المنظفات التى تحتوى على مواد الطبيعية أكثر من المواد الكيميائية سواء فيما يتعلق بتتظيف الموقد أو الزجاج أو 
عدد خاص من مجلة "بحوث في العلوم والقنون النوعيه" العبه

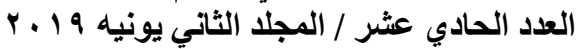

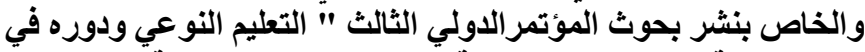

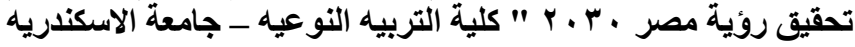

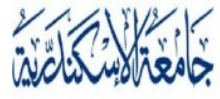

ALEXANDRIA

U N I VER S I T Y

الأثاث أو المرحاض أو تسليك الأحواض والبالوعات ، كذللك الاعتماد على الزيوت العطرية الطبيعية لتعطير المنزل والخلطات الطبيعية للقضاء على الحشرات.

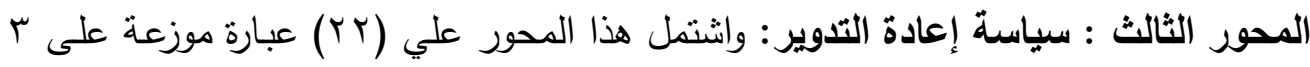
بنود تقبس إستغلال ربة الأسرة لما لديها من بعض الموارد (الغذاء ، الملابس ، المستهلكات

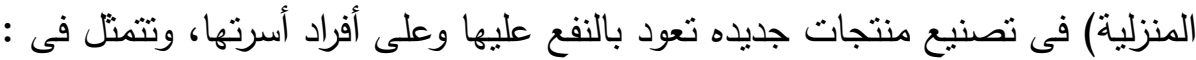

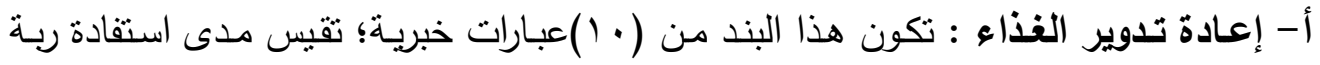

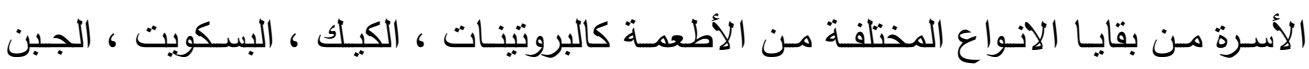
وإخالها فى عمل أصناف جديدة ، كذلك استغلال الخبز الجاف فى عمل البقسماط ، وزيوت الاطعات ، التحمير فى عمل صابون التنظيف . ب- إعادة تدوير الملابس : تكون هذا البند من (7)عبارات خبرية؛ تقيس مدى استفادة ربة

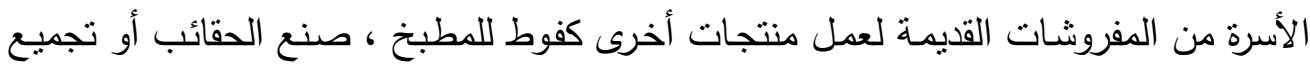
الملابسس واسـتخدامها كحشـوات ، وكـذلك إضــافة بعض اللمسـات للملابسس القديمـة لتبـدو كالجديده وحرصها لمتابعة مواقع الانترنت التى تهنم بتدوير الأقمشة .

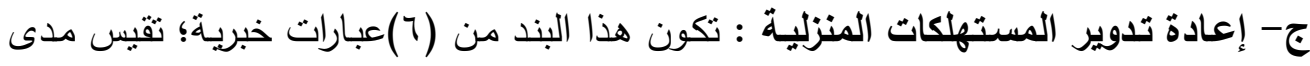

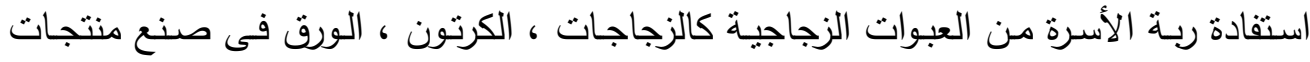

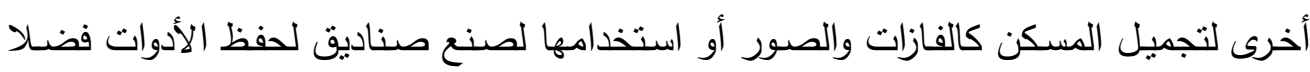
على حرصها على متابعة قنوات اليوتيوب المتخصصه فى هذا المجال . المحور الرابع : سياسة الإصلاح والصيانه : واشتنل هذا المحور علي (7 (1) عبارة تقيس سلوك ربة الأسرة في التعامل مع الأجهزة المنزلية والمرافق السكنية التى تحتاج إلى إصلاح

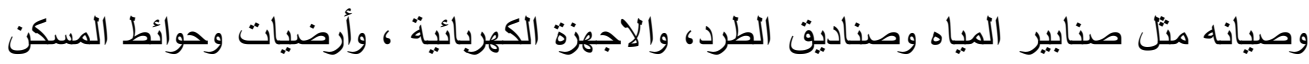
، والفحص الدورى لتوصيلات الغاز والكهرباء ، واللجوء للمختصين لصيانه الاجهزة الكهبائية 
عدد خاص من مجلة "بحوث في العلوم والقنون النوعيه" العزيه

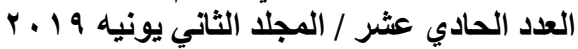

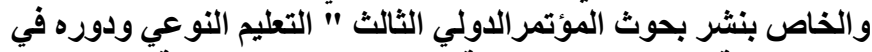

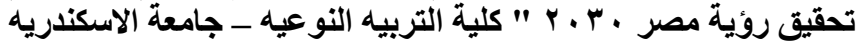

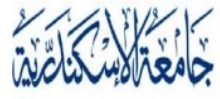

ALEXANDRIA

U N I V E R S I T Y

، فضلا عن إجراء عمليات التتظيف الدورى للخلاطات والثفاطات والثالاجه والديب فريزر والتكيف للحفاظ على كفاءتها .

\section{r - مقياس الخبرات البيئية للأبناء فى ضوء التنمية المستدامة :}

بعد الاطلاع على الدراسات السابقة المرتبطة بموضوع البحث تم إعداد هذا المقياس فى ضوء المفهوم الإجرائى الوارد بالبحث بهدف التعرف علي خبرات الأبناء البيئية فى ضوء التتمية المستدامه والتى تم إكتسابها من الأسرة ومن مصادر المعرفة المتاحة لهم والتى ساهمت فى إهى ممارستهم السـلوكيات الايجابيـة فـى التعامـل مـع البيئة وتطويرهـا نحـو الأفضـل ، وقد تكـون المقباس من (OY) عبارة خبريـة تقديرية موزعة على ثناثة محاور يجيب علبها الأبناء وفقاً

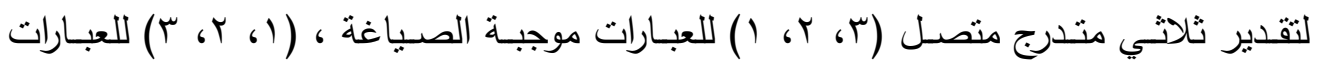
سالبة الصياغة. وبذلك تكون أعلى درجة للمقياس (107 ) وأقل درجة (ب0)، وقد تم تحديد مستويات الوعى بالخبرات البيئية طبقا لطريقة المدى كالتالى : المدى = أعلى درجة - أقل درجة = $107=0$ - $107=$ طول الفئة = المدى

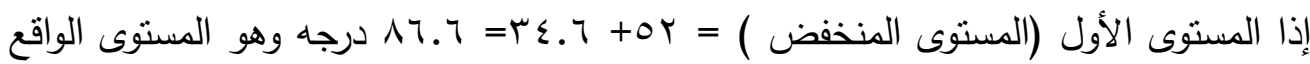
فى الفئة الحاصلة على درجات (من ror: أقل من 1.7 درجه ) من درجات المقياس، والمستوى الثانى (المستوى المتوسط ) وهو المستوى الواقع فى الفئة الحاصلة على درجات

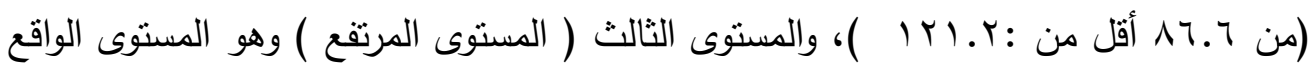
فى الفئة الحاصلة على ( Y. (Y ( فأكثر)، وتتمثل محاور المقياس فيما يلي : المحور الأول : الخبرة فى الاستفاده من الطاقة المتجدده: واشتمل هذا المحور علي (10) عبارة تقيس إدراك الأبناء لمصادر الطاقة المتجدده كالطاقة الثمسية وطاقة الرياح وطاقة المد والجزر ، طاقة بـاطن الأرض وطاقة المخلفات والنفايـات الحيوانيـة والنباتيـة ، كذلك مميزات إستخدامها كتوفير استهلاك مصسادر الطاقة التقليدية وأنها طاقة مستمرة ولا تتفذ بالاستهلاكك 
عدد خاص من مجلة "بحوث في العلوم والقنون النوعيه" العزيه

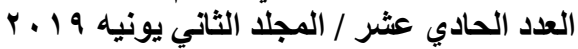

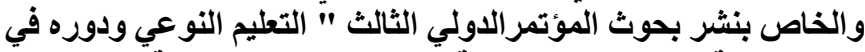

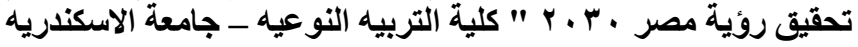

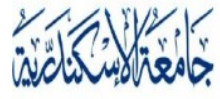

ALEXANDRIA

U N I VER S I T Y

كما أنها طاقة نظيفة تقلل من التلوث ولا تضر بصحة الانسان وتعمل على تجنب الضوضاء وتساهم فى تقليل ظاهرة الاحتباس الحرارى فضلا عن أهميتها للمستقبل وللاجيال القادمة . المحور الثانى : الخبرة فى إدارة الموارد البيئة : واشتمل هذا المحور علي (Yr) عبارة تقيس سـلوك الأبنـاء فـى حسـن التعامـل مـع المـوارد البيئيـة مـن ميـاه ، كهربـاء ، هـواء ، مسـكن وممتلكات عامة كالثوارع والحدائق ، وتتمثل فى الحرص على عدم فتح الصنبور أثناء غسيل الاسنان او الوضوء ، وعدم ملء بانيو الاستحمام ، الاهتمام بابلاغ مسئولى المدرسـة عن أى أعطال فى توصيلات المياه ، الحرص على غلق الانوار والاجهزة كالكمبيوتز فى حالة عدم الاستعمال ، والاهتمام بنزع فيشـة الثـاحن والسخان بعد الانتهاء من الاستخدام ، التقليل من استخدام معطرات الجسم والحرص على زراعة النباتات لنتقية الهواء الداخلى للمسكن ، وإزالة الأتربـه المتراكمـه على الأثاث ، فضـلا عن الحفاظ على نظافة الثـوارع والحدائق والمدرسـة ، وعدم إلقاء أى مخلفات تلوث نهر النبل ، وعدم التخريب فى أثناث المدرسـة أو الاتلاف فى محتوبات الحدائق والمتنزهات المحور الثالث : خبرة مواجهة المشكلات البيئية : واشتمل هذا المحور علي (0 1) عبارة تقيس ممارسات الأبناء وتطوعهم فى حل المشكلات البيئية ، وتتمثل فى مدى المشاركة فى تشجير الثوارع المحيطة بالمنزل أو المدرسة ، والاشتراك مع الجيران فى تجميل مدخل العمارة السكنية ، الاقبال على الاشتراك فى المعارض البيئية ، والحرص على الاشتراك فى حملات نظافة البيئة التهى ينظمها الحى أو المنظمـات البيئية ، والاشتراك فى الأنشطة التى تهدف تجميل سـور وحوائط المدرسـة ، المبادرة بعمل لافتات إرثـادية للحث على ترشيد استههلك المياه والطاقـة ونظافـة البيئة ، المشـاركة بالمناقتـات مـع المدرسين والزملاء حـول مشكلات البيئة وطرق حلها ، وكذلك حضور الندوات البيئية التى ينظمها النادى أو المدرسة . تقنين أدوات الدراسة: يقصد بتقتين الأدوات قياس صدق وثبات الأدوات . أولاً: مقياس سياسات الإلتزام البيئى لربة الأسرة . 


\section{صدق المقياس : إعتمدت الباحثنان في ذلك على كل من:}

صـق المحتـوى Validity Content: وذلك بعرض المقياس على مجموعة من الأسـاتذة

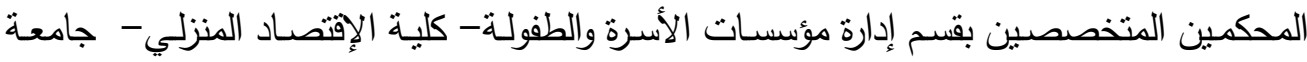
حلوان ، معهد الدراسات والبحوث البيئية - جامعة عين شمس ، لإبداء الرأي في مدى ملأئمة الإسة أسئلة المقياس والإستجابات للعبارات وصياغتها لما تهدف إلى تجميعه من معلومات وبيانات.

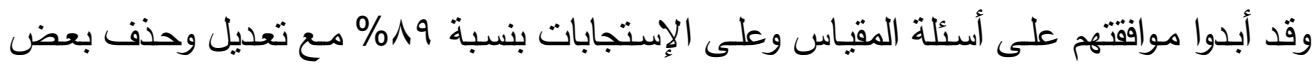
العبارات في بعض المحاور ، وقامت الباحثتان بالتعديلات المشار إليها. - صدق التكوين Construct Validity: تم حساب صدق التكوين بطريقة صدق الإتساق الداخلى عن طريق إيجاد معامل الإرتباط بإستخدام معامل "بيرسون"، لكل محور (سياسة التخفيض

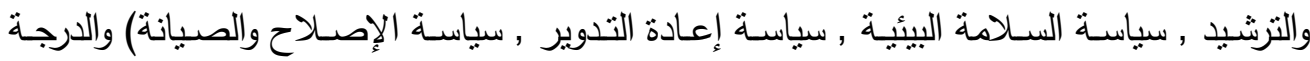

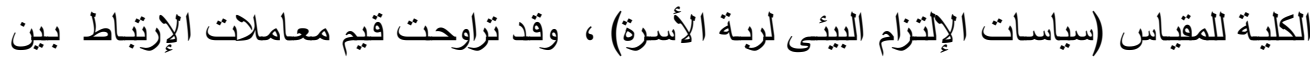

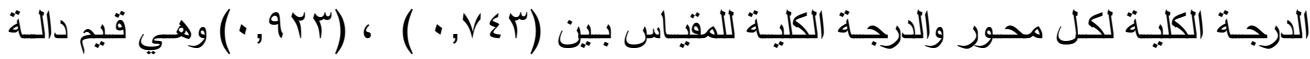
إحصائًا عند مستوى دلالة ا ب,. ، ، مما يدل على تجانس محاور المقياس والدرجة الكلية له كما

بتضح من جدول (1)

جدول ( ) قيم معاملات الارتباط بين الدرجة الكلية لكل محور والارجة الكلية لمقياس

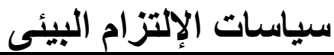

\begin{tabular}{|c|c|c|}
\hline 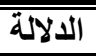 & الارتباط & محاور مقياس سياسات الإلتزام البيئى لربة الأسرة \\
\hline$\because .1$ & $. . V \leqslant \Gamma$ & سياسة التخفيض والترشيد \\
\hline$\because \cdot 1$ &. .119 & سياسة السلامة البيئية \\
\hline$\because \cdot 1$ & $.9 \times r$ & سياسة إعادة التدوير \\
\hline$\because \cdot 1$ &..$\vee \vee 0$ & سياسة الإصلاح والصيانة \\
\hline
\end{tabular}

معامـل الثبات: تم حسـاب الثبات لـقيـاس سياسـات الإلتزام البيئى لربـة الأسـرة بإستخدام طريقـة ألفاكرونباخ Alpha Cronbach ، معامل اسبيرمان براون Spearman-Brown، جيوتمان 
Guttman وكانت قيم الإرتباط دالة عند مستوى ا .,. ل لاقتربها من الواحد الصحيح كما يتضح من جدول (r) ، مما يدل على ثبات المقياس وصلاحيته للنطبيق.

\begin{tabular}{|c|c|c|c|}
\hline 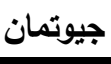 & اسبيرمان براون & 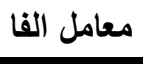 & محاور مقياس سياسات الإلتزام البيئى لربة الأسرة \\
\hline . ver & $\cdot . \Lambda \cdot 1$ & .. 144 & سياسة التخفيض والترشيد \\
\hline..$\wedge v \mu$ & .941 & $\cdot . \wedge \wedge \varepsilon$ & سياسة السلامة البيئية \\
\hline$\therefore \vee \wedge$. &..$\wedge r v$ & . va & سياسة إعادة التدوير \\
\hline$. . \wedge 9 \leqslant$ & $. .9 \leq 7$ & $\therefore .9 .9$ & سياسة الإصلاح والصيانة \\
\hline$\cdot . \wedge \leqslant 9$ & $\therefore \vee \vee V$ & $\cdot . \Lambda \cdot r$ & ثبات المقياس ككل \\
\hline
\end{tabular}

جدول (ץ) قيم معامل الثبات لمحاور مقياس سياسات الالتزام البيئى لرية الأسرة ثانياً : مقياس الخبرات البيئية للأبناء فى ضوء التتمية المستدامة: صدق المقياس : إعتمدت الباحثتان في ذلك على كل من: 1- صدق المحتوى Validity Content: وذلك بعرض المقياس على مجموعة من الأساتذة المحكمين المتخصصين بقسم إدارة مؤسسات الأسرة والطفولة- كلية الإقتصاد المنزلي - جامعة حلوان ، معهد الدراسـات والبحوث البيئية - جامعة عين شمس لإبداء الرأي في مدى ملائمـة عبارات المقياس وصياغتها لما تهدف إلى تجميعه من معلومات وبيانات. وقد أبدوا موافقتهم على عبارات المقياس بنسبة ه1\% مـع تعديل وحذف بعض العبارات ، وقامت الباحثة بالتعديلات المشار إليها. صدق التكوين Construct Validity: تم حساب صدق التكوين بطريقة صدق الإتسـاق الداخلي عن طريق إيجاد معامل الإرتباط بإستخدام معامل "بيرسون"، بين الدرجـة الكليـة لكل محور(الخبرة فى الاستفادة من الطاقة المتجددة , خبرة مواجهة المشكلات البيأية , خبرة

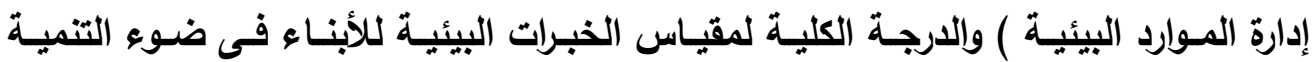
المستـامة ، وقد تزاوحت قيم معاملات الإرتبـاط بين الدرجة الكلية لكل محور والدرجة الكلية 


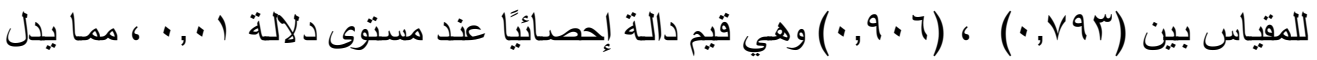

على تجانس عبارات ومحاور المقياس والدرجة الكلية له كما يتضح من جدول (r) جدول (ץ) قيم معاملات الارتباط بين الدرجة الكلية لكل محور والدرجة الكلية لمقياس

الخبرات البيئية للأبناء فى ضوء البن التنمية المستدامة

\begin{tabular}{|c|c|c|}
\hline 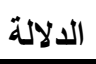 & الارتباط & محاور مقياس الخبرات البيئية للأبناء فى ضوء التتمية المستدامة \\
\hline$\ldots 1$ & .9 .7 & الخبرة فى الاستفادة من الطاقة المتجددة \\
\hline$\ldots 1$ &..$\wedge 01$ & خبرة إدارة الموارد البيئية \\
\hline$\ldots 1$ & .var & خبرة مواجهة المشكلات البيئية \\
\hline
\end{tabular}

معامـل الثبات : تم حساب الثبات لمقياس الخبرات البيئية للأبناء فى ضوء التتمية المستدامة

Spearman- يإستخدام طريقة ألفاكرونباخ Alpha Cronbach ، معامل اسبيرمان براون Brown، جيوتمان Guttman وكانت قيم الإرتباط دالة عند مستوى ا +, • لاقترابها من الواحد الصحيح كما يتضح من جلول (ع) مما يدل على ثنات المقياس وصلاحيته للنطبيق.

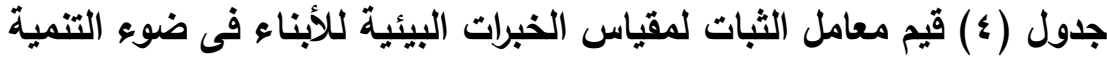

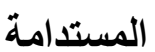

\begin{tabular}{|c|c|c|c|}
\hline جيوتمان & اسبيرمان براون & 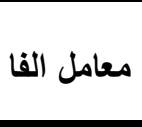 & أبعاد مقياس الخبرات البيئية للأبناء فى ضوء التتمية \\
\hline.$\wedge \circ r$ & $\therefore .9 .9$ &. .170 & الخبرة فى الاستفادة من الطاقة المتجددة \\
\hline.$V r_{1}$ & . VA4 & $\cdot v \leq r$ & خبرة إدارة الموارد البيئية \\
\hline$\cdot .9 \cdot r$ &. .904 &. .917 & خبرة مواجهة المشكلات البيئية \\
\hline$\because \vee \vee q \leq$ & $. \wedge \leqslant r$ & $\cdot . \Lambda \cdot v$ & ثبات المقياس ككل \\
\hline
\end{tabular}


تم إجـراء المعالجـات الإحصـائية بإسـتخدام برنـامج Spss.x لتحديــ المتوسـطات

الحسابية ، والإنحراف المعياري ، والتكرارات ، والنسب المئويـة ، ومعامل إرتبـاط بيرسـون ، الفروق بين المتوسطات بإستخدام إختبار T.Test ، وتحليل التباين في إتجاه واحد بإستخدام

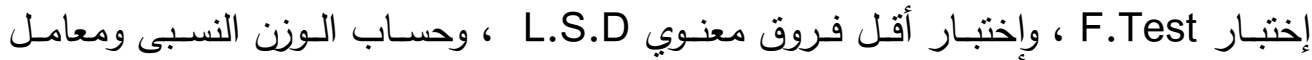
الإنحدار وذلك من أجل إستخراج النتائج ومناقتنتها وتفسيرها. النتائج تحليلها وتفسيرها

أولاً: النتائج الوصفية 1 ـ وصف عينة البحث الأساسية :

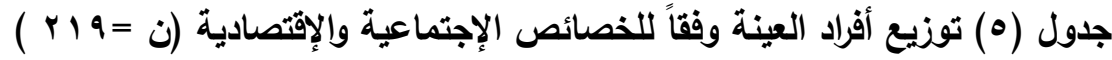

\begin{tabular}{|c|c|c|c|}
\hline النسبة المئوية \% & العدد & الفئة & البيان \\
\hline$\%$ \% & $1 \leqslant \mu$ & 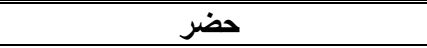 & \multirow{2}{*}{ محل الإقامة } \\
\hline$\%^{r} \varepsilon, v$ & V4 & ريف & \\
\hline$\% 07,7$ & IY\& & تعمل & \multirow{2}{*}{ الحالة الوظيفية للام } \\
\hline$\% \leqslant r, \varepsilon$ & 90 & لا تعمل & \\
\hline$\% \varepsilon \cdot, r$ & $\Lambda \Lambda$ & ذذكور & \multirow{2}{*}{ جنس الإبن } \\
\hline$\% \circ 9, \wedge$ & $1 \% 1$ & إناث & \\
\hline$\% \%^{Y}, \wedge$ & 0. & منذفض (إعدادية فافْلّ) & \multirow{3}{*}{ مستوى تعليم الأم } \\
\hline$\% r r, r$ & $V \mu$ & متوسط (ثانوية، فوق متوسط) & \\
\hline$\% \leqslant r, \wedge$ & 99 & مرتفع (جامعي ، فوق جامعي) & \\
\hline$\% 19,5$ & \&r & أقلّ من · r سنة & \multirow{3}{*}{ مدة الزواج } \\
\hline$\% \leqslant r, \wedge$ & 99 & من · rاسنة لاقل من · r سنة & \\
\hline$\%$ \% & $\Lambda 1$ & من · ب سنة فأكثر & \\
\hline$\%$ \%V, & $\%$ & 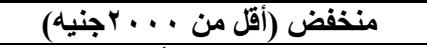 & \multirow{3}{*}{ الاخل الثهرى للأسرة } \\
\hline$\%^{r+1}, 1$ & $7 \Lambda$ & 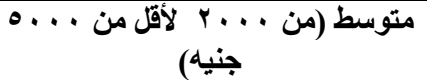 & \\
\hline$\% \leqslant 1,0$ & 91 & مرتفع (من ... & \\
\hline$\%$ \%1, 9 & v. & 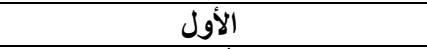 & \multirow{3}{*}{ ترتيب الإبن بين أخوته } \\
\hline$\% \leqslant 1,4$ & 91 & الأوسط & \\
\hline$\%$ \%४, & 01 & 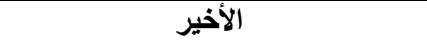 & \\
\hline
\end{tabular}


عدد خاص من مجلة "بحوث في العلوم والقنون النوعيه" التونيه

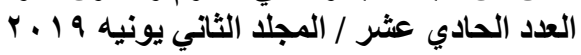

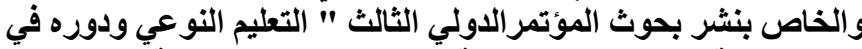

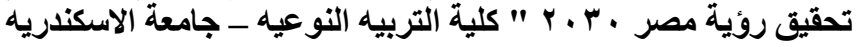

يتضح من جدول (0) أن الغالبية العظمى من الأمهات عينة البحث يقمن فى الحضر بنسبة

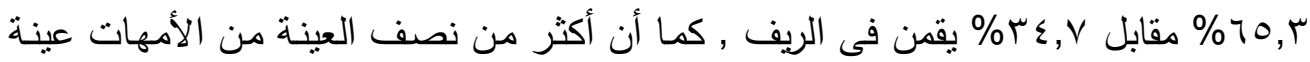

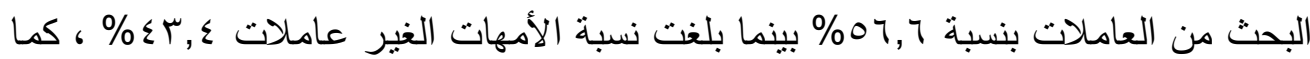

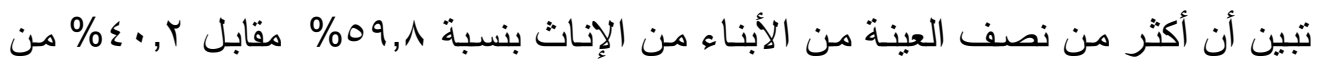

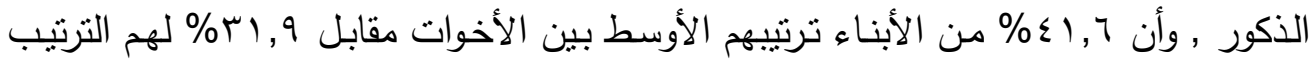

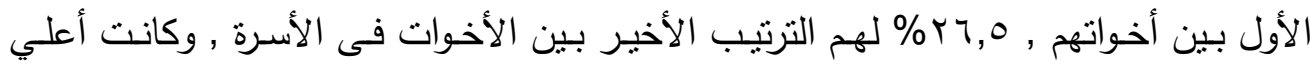

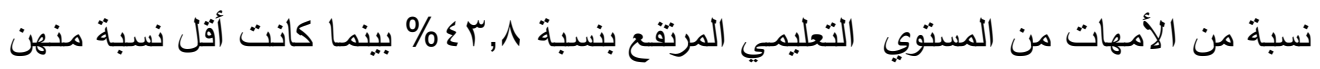

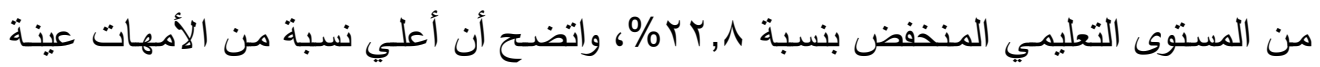

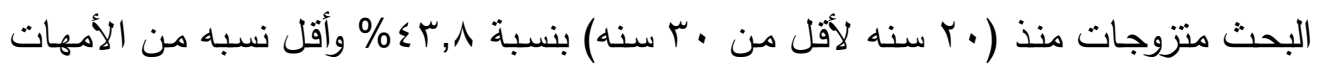

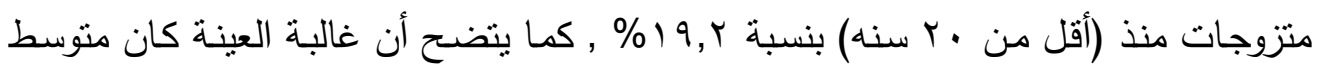

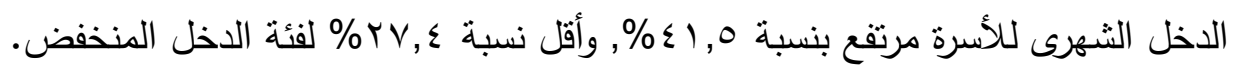
r

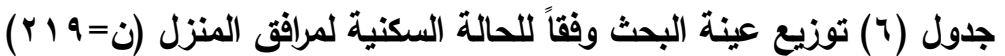

\begin{tabular}{|c|c|c|}
\hline النسبة\%\% & العدد & 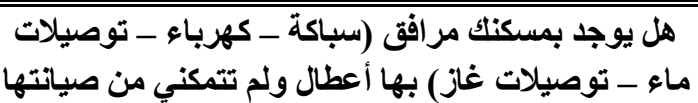 \\
\hline$\%$ Y I. & $\leq 4$ & يوجد \\
\hline$\% \vee \wedge .9$ & IVr & لا يوجد \\
\hline $0 \% 1 \ldots$ & 199 & المجموع \\
\hline
\end{tabular}

يتضح من جدول (7) أن و>1.9\% من ربات الأسر عينة البحث لايوجد لديهم مرافق بها

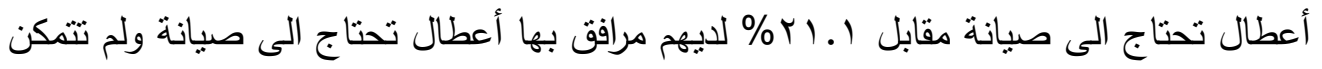
من صيانتها . من 
r - نوعية المرافق التى تحتاج إلى صيانة :

جدول (V) توزيع عينة البحث وفقاً لنوعية المرافق التى تحتاج الى صيانة بالمسكن (ن = צ ؛ ؛

\begin{tabular}{|c|c|c|}
\hline النسبة المئوية \% & العدد & المر افق التى بها أعطال وتحتاج الى صيانة \\
\hline$\% \leqslant 1 . \varepsilon$ & 19 & توصيلات الكهرباء و الإضاءة \\
\hline$\% 19.0$ & 9 & توصيلات السباكة ومرافقها \\
\hline$\%$ \%^.r & ir & توصيلات الماء ومرافقها من خلاطات وغير ها \\
\hline$\% 1 \cdot . \wedge$ & 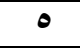 & ت ت توصيلات الغاز \\
\hline$\% 1 \ldots$ & $1 \% 0$ & 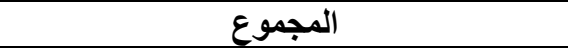 \\
\hline
\end{tabular}

يتضح من جدول (V) أن ع. §؟\% من ربات الاسر لديهن أعطال وتحتاج الى صيانة فى

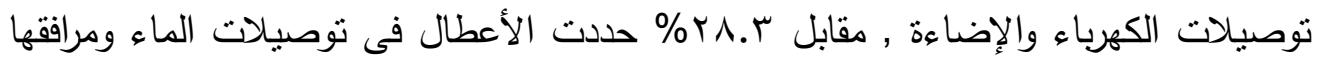

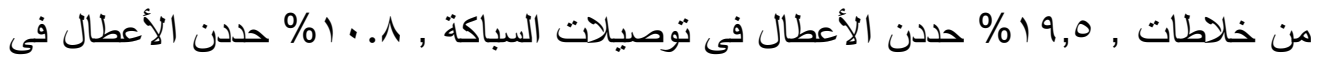

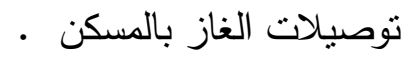

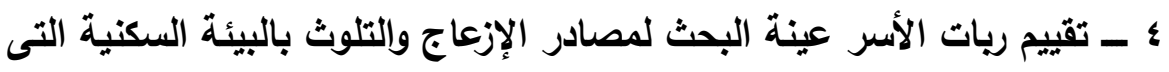

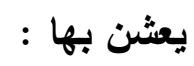

جدول (^) توزيع عينة البحث وفقاً لتقيمهم لمصادر الإزعاج والتلوث بالبيئة السكنية ( $r \mid q=\dot{0})$

\begin{tabular}{|c|c|c|}
\hline النسبة\%\% & العدد & 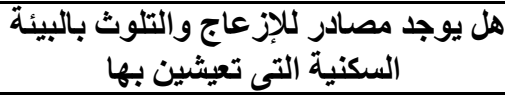 \\
\hline$\%$ & $1 \wedge \varepsilon$ & يوجذ \\
\hline$\% 10,9$ & ro & لا يوجد \\
\hline$\% 1 \ldots$ & Y19 & المجموع \\
\hline
\end{tabular}

يتضح من جدول (^) أن ؟^\% من أفراد عينة البحث يجدن أن هناك مصادر للإزعاج والتلوث بالبيئة السكنية النى يعشن بها , مقابل 0,9 10 لايوجد لديهن مصادر للإزعاج والتلوث بالبيئة

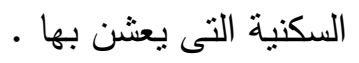




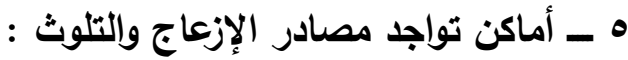

جدول (9) توزيع عينة البحث وفقاً لأماكن تواجد مصادر الإزعاج والتلوث (ن= \& م ا )

\begin{tabular}{|c|c|c|}
\hline النسبة المئويةة\% & العدد & 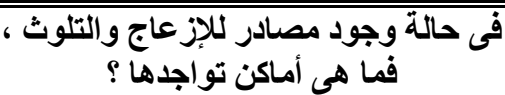 \\
\hline$\overline{\% \text { \%r.1 }}$ & 09 & داخل المسكن \\
\hline$\% \leqslant Y .\{$ & $V \wedge$ & قريب من المسكن \\
\hline$\%$ Y & $\varepsilon V$ & بعيد عن المسكن \\
\hline$\%$ & $11 \leqslant$ & المجموع \\
\hline
\end{tabular}

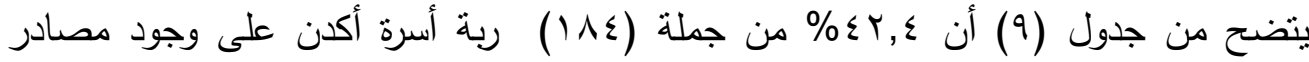
للإزعاج والتلوث بالقرب من المسكن , مقابل ا,rr\% يجدونها داخل المسكن ,\%ץ\% يجدونها

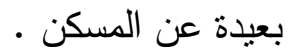

7 - د درجة مشاركة الأبناء فى الأنشطة البيئية :

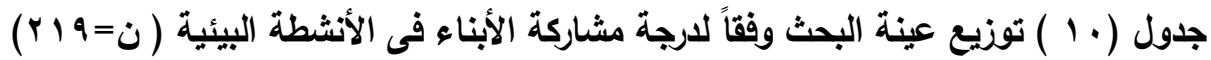

\begin{tabular}{|c|c|c|}
\hline النسبة\% & العدد & 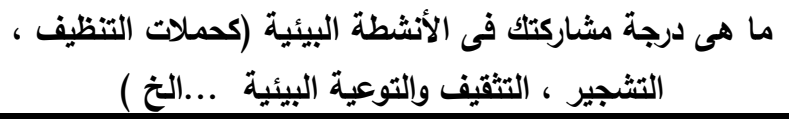 \\
\hline$\% \circ$ r. $q$ & 117 & لا أثشارك \\
\hline$\%$ rv. 9 & 11 & أشارك إلى حـ ما \\
\hline$\% 19 . r$ & $\varepsilon r$ & أشثارك برجه كبيرة \\
\hline$\% 1 \ldots$ & $r 19$ & المجموع \\
\hline
\end{tabular}

يتضح من جدول (·() أن أكثر من نصف الأبناء للأمهات عينة البحث لايشاركون فى

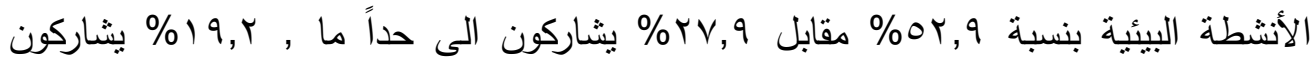
بدرجة كبيرة فى الأنشطة البيئية . 


\section{V ـ أكثر سياسات الإلتزام البيئى لريات الأسر عينة البحث :}

جدول (11) الوزن النسبى لسياسات الإلتزام البيئى لريات الأسر عينة البحث (ن=9 ا Y )

\begin{tabular}{|c|c|c|c|}
\hline الترتيب & النسبة المئوية\% & الوزن النسبي & سياسات الالتزام البيئى لرية الأسرة \\
\hline الأول & $\%$ \%४.r & rAl & سياسة التخفيض والترشيد \\
\hline الثالث الث & $\%$ \%r.t & $r \leqslant 1$ & سياسة السلامة البيئية \\
\hline 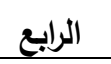 & $\%$ rr & rro & سياسة إعادة التدوير \\
\hline الثاني & $\%$ \%ч.1 & YT & سياسة الإصلاح والصيانة \\
\hline & $\% 1 \ldots$ & $1 . r 1$ & المجموع \\
\hline
\end{tabular}

يتضح من جدول (1') أن سياسة التخفيض والترشيد جأت فى الترتيب الأول كأكثر سياسات

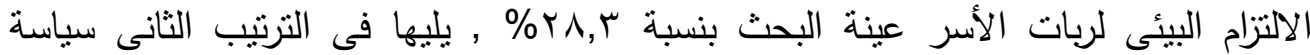

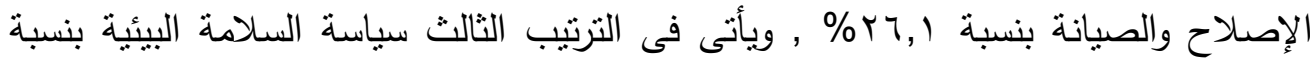

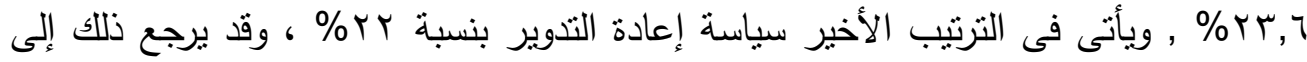
الظروف الاقتصادية التى تمر بها البلاد مما أدى إلى إرتفاع تكاليف المعيثة التى أصبحت

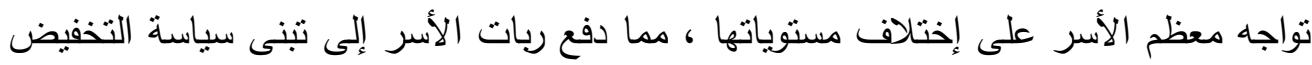

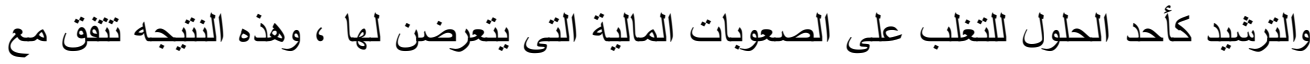

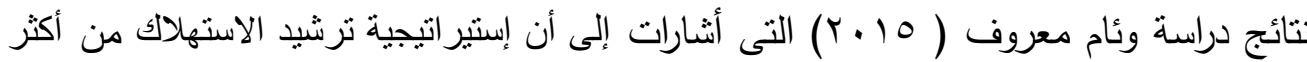

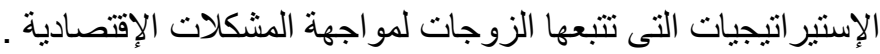

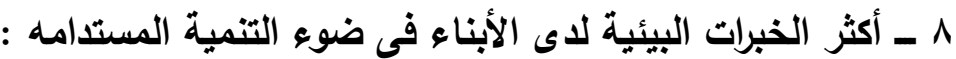

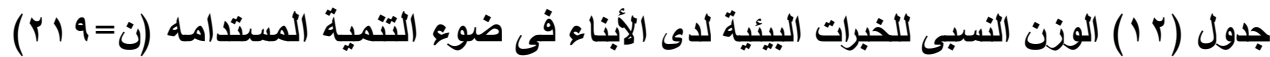

\begin{tabular}{|c|c|c|c|}
\hline الترتيب & النسبة المئويةة\% & الوزن النسبي & الخبرات البيئية للأبناء \\
\hline الاول & $\%$ & rrs & الخبرة فى الاستفادة من الطاقة المتجددة \\
\hline 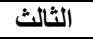 & $\%$ & rVV & خبرة مواجهة المشكلات البيئية \\
\hline 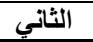 & \% \%r. & $r \otimes \Lambda$ & خبرة إدارة الموارد البيئية \\
\hline & $\% 1 \ldots$ & V79 & المجموع \\
\hline
\end{tabular}


يتضح من جدول (r ( ) أن خبرة الاستفادة من الطاقة المتجددة نأتى فى الترتيب الأول كأكثر الخبرات البيئية لدى أبناء ربات الأسر عبنة البحث بنسبة جس\% , يليها خبرة إدارة الموارد البيئية

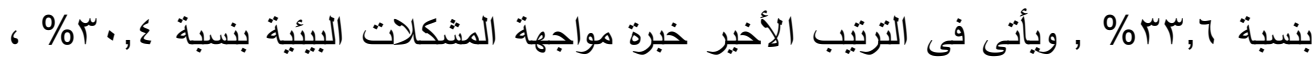
وقد يرجع ذلك إلى أن بعض المناهج التعليمية التى يدرسها الطلاب فى تلك المرحلة العمرية تتتاول موضوعات عن الطاقة المتجددة ومصادرها مما ساهم فى رفع خبراتهم فى هذا المجال . 9 - مستوى سياسات الإلتزام البيئى لريات الأسر عينة البحث :

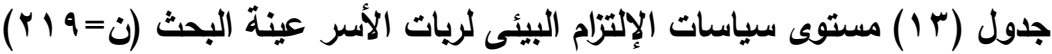

\begin{tabular}{|c|c|c|c|c|c|c|c|c|}
\hline \multicolumn{2}{|c|}{ المجموع } & \multicolumn{2}{|c|}{ مرتفع } & \multicolumn{2}{|c|}{ متوسط } & \multicolumn{2}{|c|}{ منخفض } & \\
\hline النسبة\% & العدد & 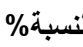 & 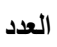 & النسبة\% & 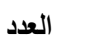 & النسبة\% & العدد العد & \\
\hline \multirow[t]{2}{*}{$1 \ldots$} & \multirow[t]{2}{*}{119} & \multicolumn{2}{|c|}{ 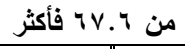 } & \multicolumn{2}{|c|}{ 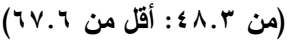 } & \multicolumn{2}{|c|}{ 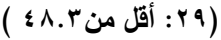 } & سياسة التخفيض والترشيد \\
\hline & & A. & $V \leq$ & $0 . r r$ & 11. & 10.9 & ro & \\
\hline \multirow[t]{2}{*}{$1 \ldots$} & \multirow[t]{2}{*}{ Y19 } & \multicolumn{2}{|c|}{ من 9.9 فأكثر } & \multicolumn{2}{|c|}{ 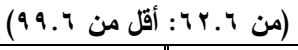 } & \multicolumn{2}{|c|}{ 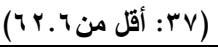 } & سياسة السلامة البيئية \\
\hline & & r..9 & $\Delta 9$ & rv.q & Ar & ro.r & $\checkmark v$ & \\
\hline \multirow[t]{2}{*}{$1 \ldots$} & \multirow[t]{2}{*}{ PIq } & \multicolumn{2}{|c|}{ من \. \ه فأكثر } & \multicolumn{2}{|c|}{ 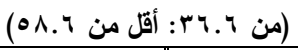 } & \multicolumn{2}{|c|}{ 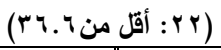 } & سياسة إعادة التدوير \\
\hline & & $Y \varepsilon . Y$ & or & $r \varepsilon . V$ & V & $\leqslant 1.1$ & 9. & \\
\hline \multirow[t]{2}{*}{$1 \ldots$} & \multirow[t]{2}{*}{ Y19 } & \multicolumn{2}{|c|}{ من r. r فأكثر } & \multicolumn{2}{|c|}{ (من צ.ד r: أقل من rv.r) } & \multicolumn{2}{|c|}{ 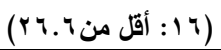 } & سياسة الإصلاح والصيانة \\
\hline & & rq. & $7 \leq$ & $\leqslant \Lambda .9$ & $1 \cdot v$ & Y1.9 & $\leqslant \Lambda$ & \\
\hline \multirow[t]{2}{*}{$1 \cdots$} & \multirow[t]{2}{*}{ 1) } & \multicolumn{2}{|c|}{ 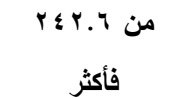 } & \multicolumn{2}{|c|}{ 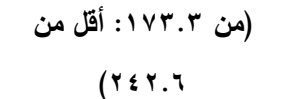 } & \multicolumn{2}{|c|}{ من (ع • ا: أقل } & سياسات الإلتزام البيئى ككل \\
\hline & & ५ Q.V & 90 & r.. & $\Lambda_{1}$ & $r r . r$ & VT & \\
\hline
\end{tabular}

يتضح من جدول (r ا () إختلاف مستوى ربات الأسر عينة البحث فى سياسات الإلتزام البيئى حيث كانت النسبة الأكبر من ربات الأسر ذات مستوى منوسط فى كل من سياسة التخفيض

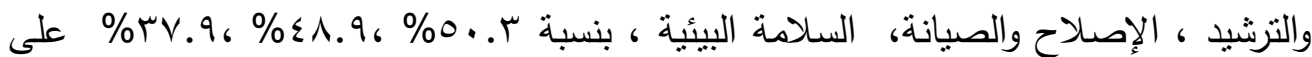


التوالى، وكانت النسبة و, 9r\% لسياسات الإلتزام البيئى ككل لربات الأسر ذات المستوى المتوسط , فى حين كان مستوى سياسة إعادة التدوير منخفض بنسبة ر,اء\% ويمكن تفسير ذلك بأن سياسة إعادة التدوير تحتاج الى مهارة خاصة لدى ربة الأسرة كما أن ثقافة إعادة

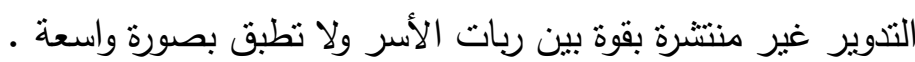

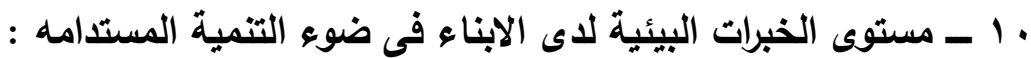

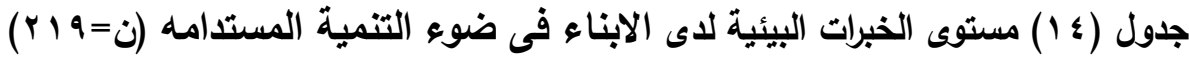

\begin{tabular}{|c|c|c|c|c|c|c|c|c|}
\hline \multicolumn{2}{|c|}{ المجموع } & \multicolumn{2}{|c|}{ 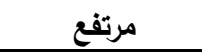 } & \multicolumn{2}{|c|}{ متوسط } & \multicolumn{2}{|c|}{ منخفض } & لالمستوى \\
\hline النسبة\%\% & العدد & النسبة\% النسب & العدد & 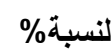 & العدد & 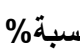 & العدد & الخبرات \\
\hline \multirow[t]{2}{*}{$1 \ldots$} & \multirow[t]{2}{*}{ riq } & \multicolumn{2}{|c|}{ من •ب فأكثر } & \multicolumn{2}{|c|}{ (من هץ: أقل من } & \multicolumn{2}{|c|}{ 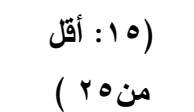 } & الخبرة فى الاستفادة من الطاقة \\
\hline & & rะ. & $v_{0}$ & $\leqslant 0.7$ & I.. & $r \cdot . r r r y$ & ؛ & \\
\hline \multirow[t]{2}{*}{$1 \ldots$} & \multirow[t]{2}{*}{ r19 } & \multicolumn{2}{|c|}{ من 1 هـ فأكثر } & \multicolumn{2}{|c|}{ 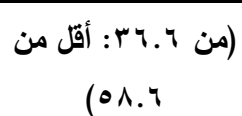 } & \multicolumn{2}{|c|}{ 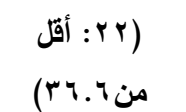 } & خبرة إدارة الموارد البيئية \\
\hline & & $r 1.9$ & v. & $\leq 0 . r$ & 99 & rr.1 & o. & \\
\hline \multirow[t]{2}{*}{$1 \ldots$} & \multirow[t]{2}{*}{ r 19} & \multicolumn{2}{|c|}{ من • ب فأكثر } & \multicolumn{2}{|c|}{ (من هץ: أقل من } & \multicolumn{2}{|c|}{ 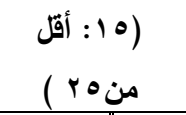 } & خبرة مواجهة المشكلات البيئية \\
\hline & & ro.1 & $\Delta 0$ & $\leqslant$ r. & 94 & rr.s & $v_{1}$ & \\
\hline \multirow[t]{2}{*}{$1 \ldots$} & \multirow[t]{2}{*}{ r 19} & \multicolumn{2}{|c|}{ 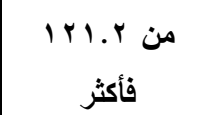 } & \multicolumn{2}{|c|}{ 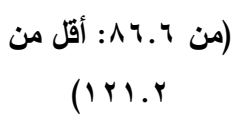 } & \multicolumn{2}{|c|}{ من (Y ه : أقل } & الخبرات البيئية ككل \\
\hline & & $r \leqslant .1$ & or & $\leq 0 . r$ & 99 & $r .$. & iv & \\
\hline
\end{tabular}

يتضح من جدول (ع () إختلاف مستوى الخبرات البيئية لأبناء ربات الأسر عينة البحث فى

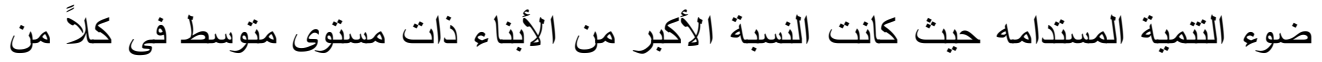
الخبرة فى الاستفادة من الطاقة المتجددة , خبرة إدارة الموارد البيئية , خبرة مواجهة المشكلات 


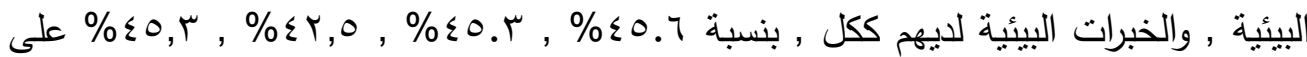

\section{ثانيًا: النتائج في ضوء فروض البحث :}

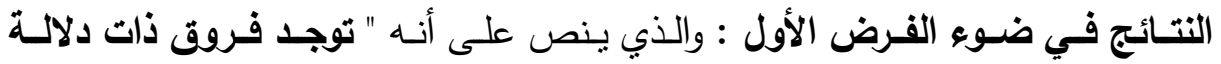

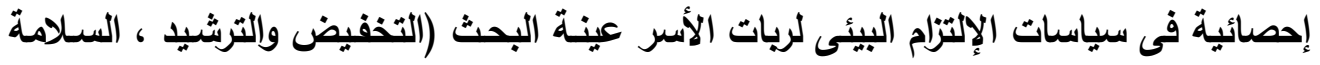

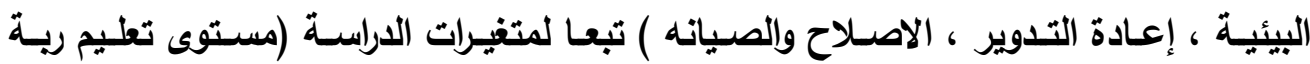

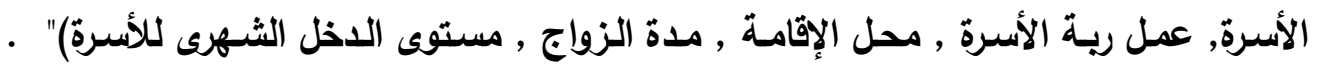
وللتحقق مـن صـحة هذا الفـرض تـم إجـراء اختبـار (ت) للوقوف علـي دلالـة الفـروق بـين

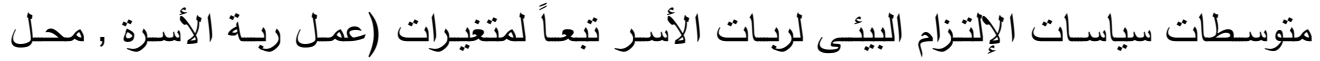
الإقامة) , وتحليل التباين لإيجاد قيمـة (ف) للوقوف علي دلالة الفروق في سياسات الإلنزام

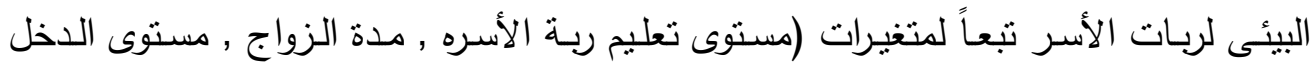

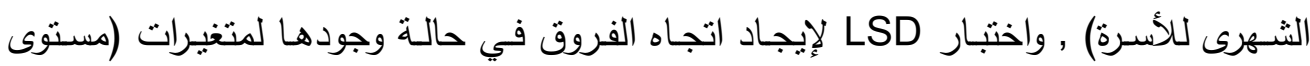

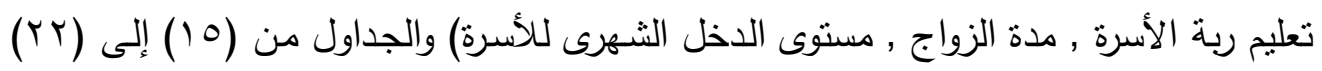
توضح ذلك . 
جدول (10) دلالة الفروق في متوسطات سياسات الإلتزام البيئى لرية الأسرة تبعاً لمتغير عمل ربة

$$
\text { الأسرة (ن= (r) }
$$

\begin{tabular}{|c|c|c|c|c|c|c|}
\hline 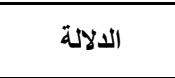 & قيمة (ت ) & الحرية & 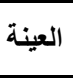 & الانحرافياري & المتوسط الحسابي & عمل ربة الأسرة \\
\hline \multicolumn{7}{|c|}{ سياسة التخفيض والترشيد } \\
\hline \multirow{2}{*}{ لصالح العاملات 1 ', } & \multirow{2}{*}{24.229} & \multirow{2}{*}{217} & 124 & 6.610 & 77.771 & تعمل \\
\hline & & & 95 & 5.029 & 51.296 & لا تعمل \\
\hline \multicolumn{7}{|c|}{ سياسة السلامة البيئية } \\
\hline \multirow{2}{*}{ لصالح العاملات 1 '•• } & \multirow{2}{*}{25.293} & \multirow{2}{*}{217} & 124 & 7.258 & 99.772 & تعمل \\
\hline & & & 95 & 6.001 & 73.385 & لا تعمل \\
\hline \multicolumn{7}{|c|}{ سياسة إعادة التدوير } \\
\hline \multirow{2}{*}{ 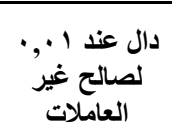 } & \multirow{2}{*}{23.381} & \multirow{2}{*}{217} & 124 & 3.215 & 32.691 & تعمل \\
\hline & & & 95 & 4.999 & 57.638 & لا تعمل \\
\hline \multicolumn{7}{|c|}{ سياسة الإصلاح و الصيانة } \\
\hline \multirow{2}{*}{ 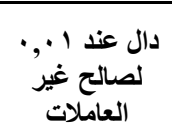 } & \multirow{2}{*}{12.036} & \multirow{2}{*}{217} & 124 & 2.024 & 27.741 & تعمل \\
\hline & & & 95 & 3.657 & 41.129 & لا تعمل \\
\hline \multicolumn{7}{|c|}{ سياسات الإلتزام البيئى لربة الأسرة ككل } \\
\hline \multirow{2}{*}{ لدال عند ا •, } & \multirow{2}{*}{12.555} & \multirow{2}{*}{217} & 124 & 10.524 & 237.975 & تعمل \\
\hline & & & 95 & 8.957 & 223.448 & لا تعمل \\
\hline
\end{tabular}

يتضح من جدول (10) وجود فروق ذات دلالة إحصائية في سياسات الإلتزام البيئى لربة

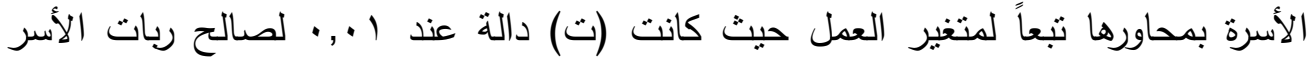
العاملات فى كلاً من سياسة التخفيض والترشيد وسياسة السلامة البيئية وسياسات الإلتزام البيئى ككل , وكانت دالة لصالح الغير عاملات فى كلاً من سياسة إعادة التدوير وسياسة ولئة الإصلاح والصيانة , ويمكن تفسير ذلك بأن خروج ربة الأسرة للعمل يزيد من إنساع دائرة 
خبراتها وإحتكاكها بالأخرين من حولها وتعرفها على المزيد من التجارب والتى تكسبها المزيد من المعرفه والخبرة وتساعدها على تقدير قيمة ما لديها من موارد وذلك بسبب عنائها فى

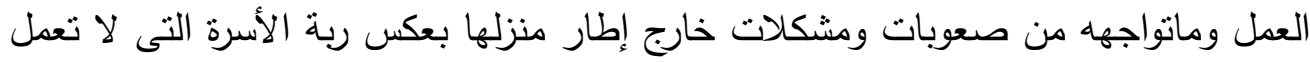
ولا تتكبد متل هذه الصعاب مما يرفع من مستوى وعيها فى ترشيد وتقنين استهلاكها والحفاظ

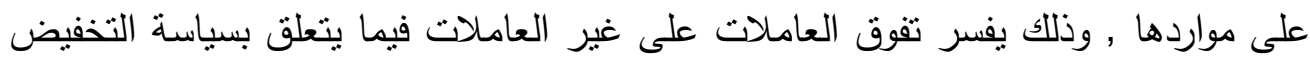

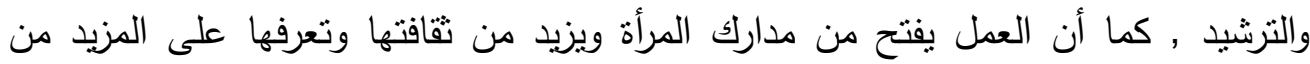
تجارب الاخرين وزيادة رصيدها من المعلومات التى تتعرف عليها من المجتمع الخارجى ومعرفتها بمصادر التلوث المختلفة والتعرف على المنتجات صديقة البيئة مما يفسر تفوق

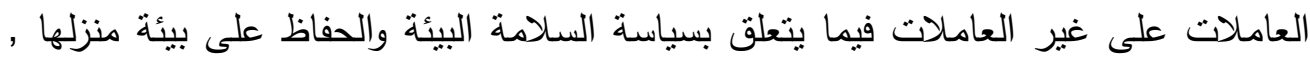
بعكس ذللك تمنلالك ربة الأسرة التى لاتعمل رصيد كافى من الوقت يسمح لها بإعادة تدوير

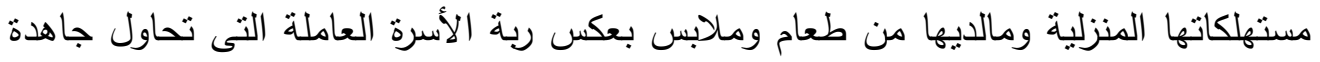
أن توفى ما عليها من مسئوليات منزلية بأبسط الطرق والوسائل مما يفسر تفوق ربة الأبرة الأسرة

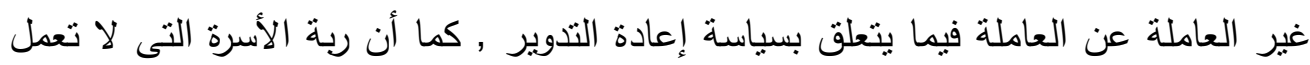

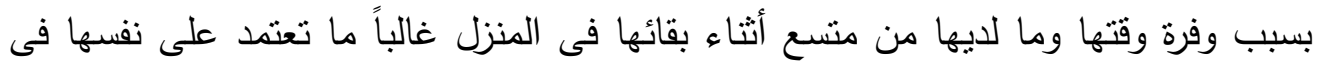

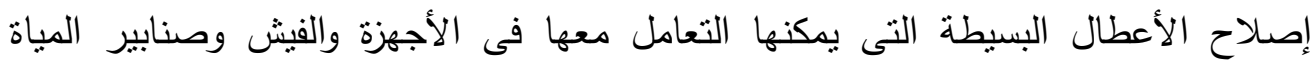
وإنسداد البالوعات وغيرها مما يفسر تفوقها فيما يتعلق بسياسة الإصلاح والصيانة , وفى لهى

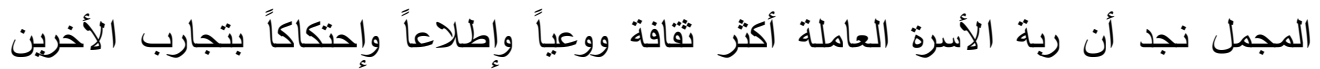
والمجتمع الخارجى مما يزيد من فرصتها فى الوعى والمعرفة ويفسر تطبيقها لسياسات الإلتزام البيئى ككل أكثر من ربة الأسرة التى لا تعمل , ويتفق ذلك ودراسة سناء النجار (Y.lV)

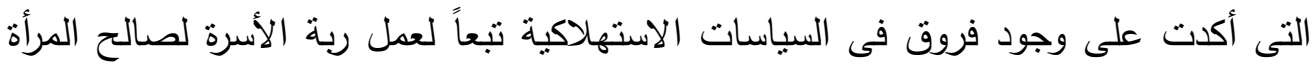

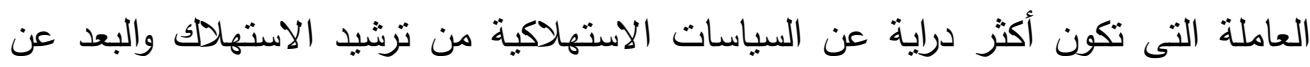

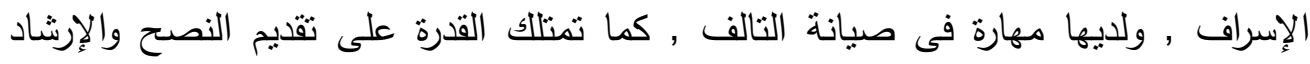


لأسرتها فى سبيل نوفير بيئة هادئة وصحية ونظيفة , وتتفق كذلك ونتائج كلاً من رشا راغب

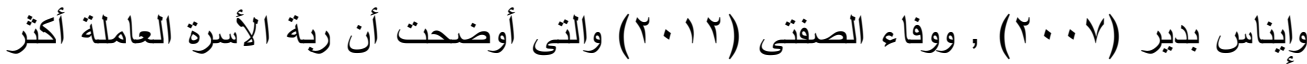
قررة على إنخاذ القرارات الخاصة بحماية البيئة المنزلية من المخاطر عن ربة الأسرة غير

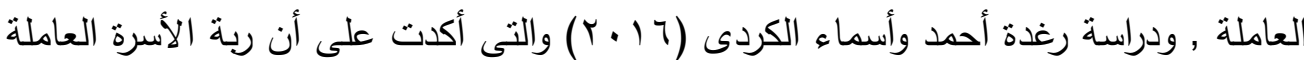
أفضل فى إدارة المخاطر المنزلية بمحاورها عن ربة الأسرة التى لاتعمل , وتتفق كذلك ودراسة

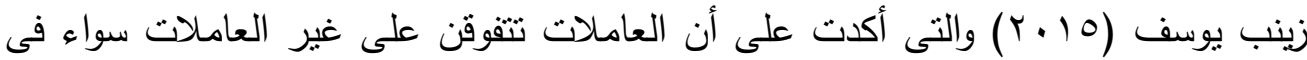

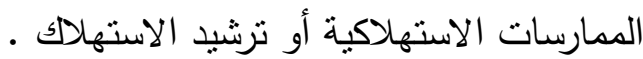

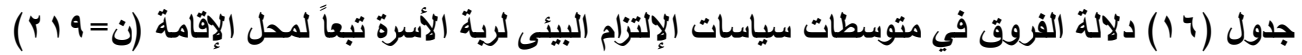

\begin{tabular}{|c|c|c|c|c|c|c|}
\hline 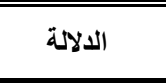 & قيمة (ت ) & لدرجات & العينة & الاتحر اف المعياري & الحستوسط & محل الإقامة \\
\hline \multicolumn{7}{|c|}{ سياسة التخفيض والترشيا } \\
\hline \multirow{2}{*}{ 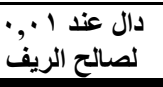 } & \multirow{2}{*}{16.357} & \multirow{2}{*}{217} & 143 & 5.001 & 63.051 & حضر \\
\hline & & & 76 & 6.358 & 82.524 & ريف \\
\hline \multicolumn{7}{|c|}{ سياسة السلامة البيئية } \\
\hline \multirow{2}{*}{ 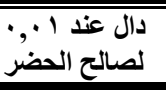 } & \multirow{2}{*}{10.445} & \multirow{2}{*}{217} & 143 & $\overline{8.201}$ & $\overline{104.257}$ & حضر \\
\hline & & & 76 & 7.335 & 92.561 & ريف \\
\hline \multicolumn{7}{|c|}{ سياسة إعادة التدوير } \\
\hline \multirow{2}{*}{ 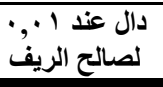 } & \multirow{2}{*}{20.443} & \multirow{2}{*}{217} & 143 & 3.621 & 441.410 & حضر \\
\hline & & & 76 & 5.593 & 63.348 & ريف \\
\hline \multicolumn{7}{|c|}{ سبياسة الإصلاح والصيانة } \\
\hline \multirow{2}{*}{ لدالح عند الحضُ" } & \multirow{2}{*}{14.274} & \multirow{2}{*}{217} & 143 & 4.001 & 45.111 & حضر \\
\hline & & & 76 & 2.628 & 30.259 & ريف \\
\hline \multicolumn{7}{|c|}{ سياسات الإلتزام البيئي لربة الأسرة ككل } \\
\hline \multirow{2}{*}{ لدال عند الريفُ" } & \multirow{2}{*}{14.521} & \multirow{2}{*}{217} & 143 & 9.421 & 253.829 & حضر \\
\hline & & & 76 & 11.296 & 268.692 & ريف \\
\hline
\end{tabular}

يتضح من جدول (7 1) وجود فروق ذات دلالة إحصائية في سياسات الإلتزام البيئى لربة

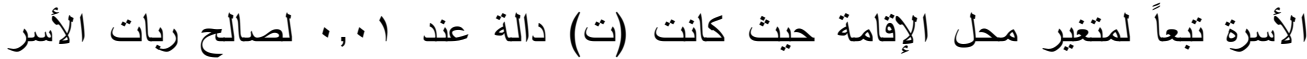

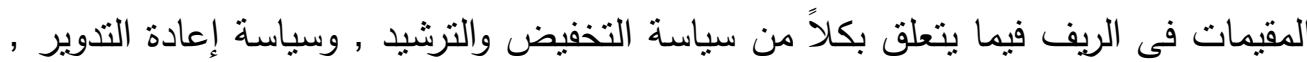


عدد خاص من مجلة "بحوث في العلوم والقنون النوعيه" العيه

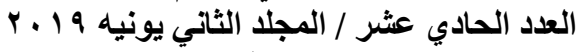

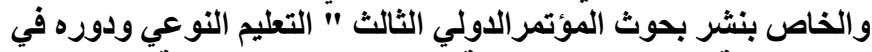

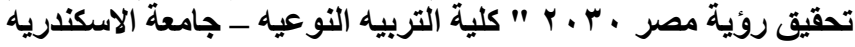

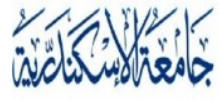

ALEXANDRIA

U N I VER S I T Y

وسياسات الالتزام البيئى ككل , ودالة لصالح ربات الأسر المقيمات فى الحضر فيما يتعلق بسياسة السلامة البيئية وسياسة الإصلاح والصيانة , وتفسر الباحثنان ذلك بأن ربات الأسر

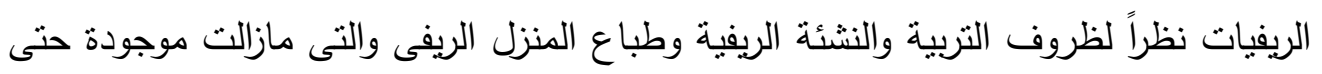

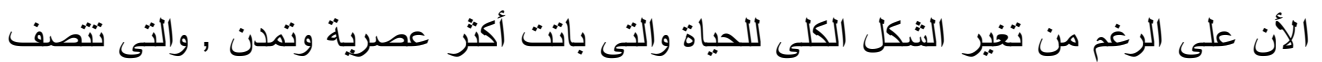
بأنها تعظم من قيمة الموارد المنزلية والاعتماد على المنزل ومنتجاته وثقافة تقدير قيمة مصادر المنزل المنتوعة من الموارد مثل الاعتماد على نربية الدواجن والحيوانات وإعداد

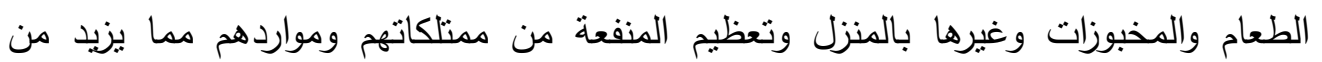
رصيدهم فيما يتعلق بترشيد وتقنين الموارد وتقدير قيمنها بعكس الحضريات اللائى يتصفن

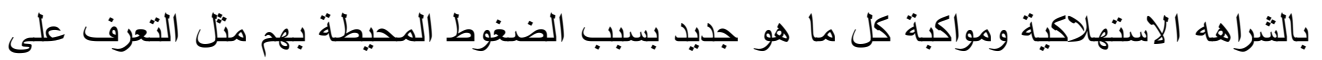

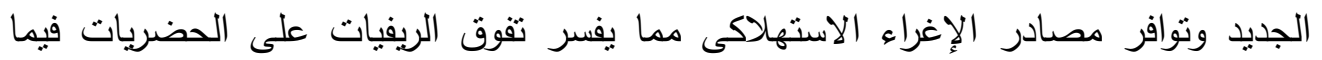

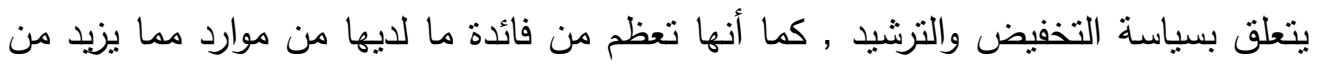

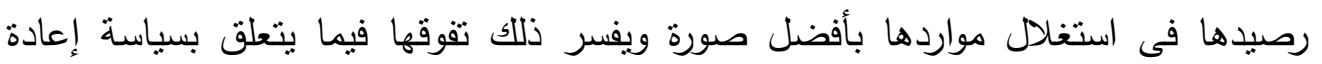

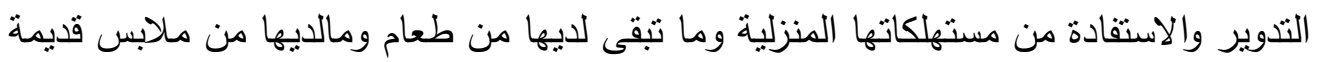

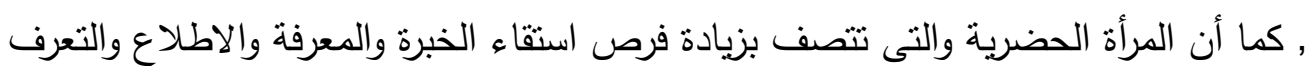

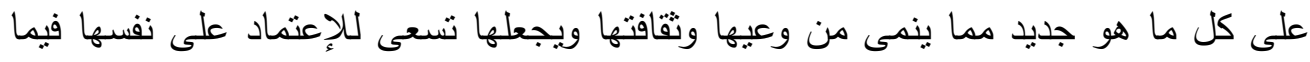

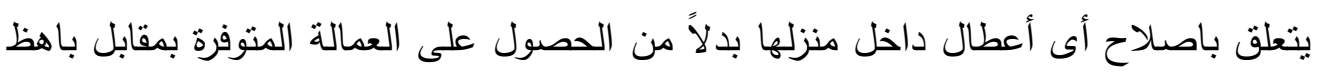

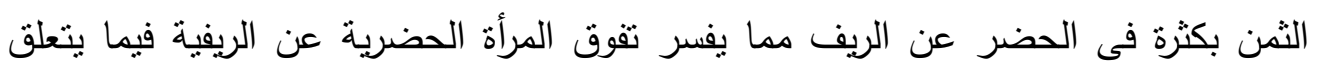
بسياسة الإصلاح والصيانة , كما أنها أكثر وعياً عن المرأة الريفية فيما يتعلق بقضائايا التلوث

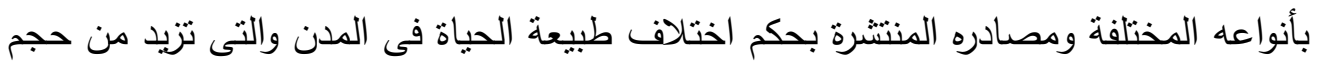
التلوث من حولها مما يفسر التزامها بسياسة السلامة البيئية عن المرأة التى تسكن فى الريف ,

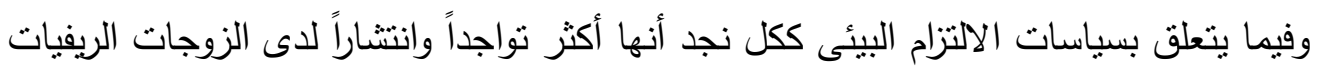
عن الحضريات بسبب ظروف المعيشة فى الريف والتى مازالت تعبر عن التمسك بقيمة لونة 
الموارد وتعظيم المنفعة منها واستغلال الموارد والطاقات البشرية والحفاظ على النظافة والطبيعة من التلوث الذى بات أكثر انتشاراً فى المدن عن القرى , وتتفق هذه النتيجة ودراسة سناء

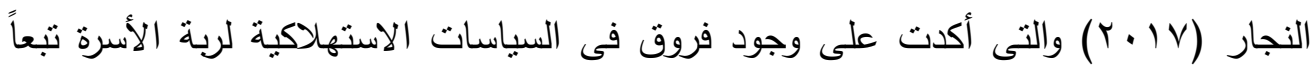

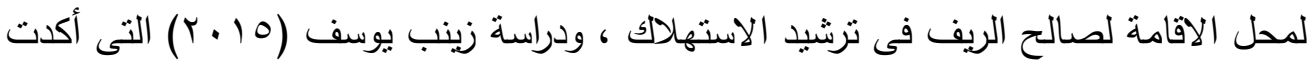

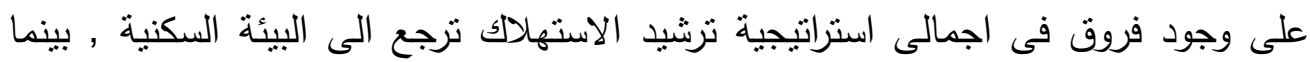

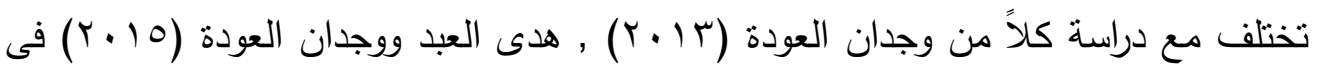
عدم وجود تباين دال احصائياً فى السلوك الاستهلاكى بمحاوره تبعاً لمنطقة السكن , وفيما

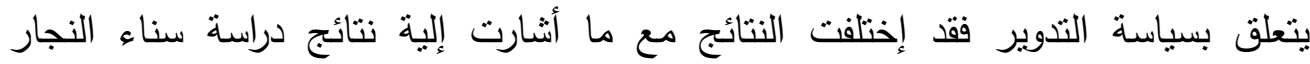
(Y. IV) يتعلق بسياسة السلامة البيئية لاى ربات الأسر الحضريات فقد أتفقت النتائج مع ما أكدته

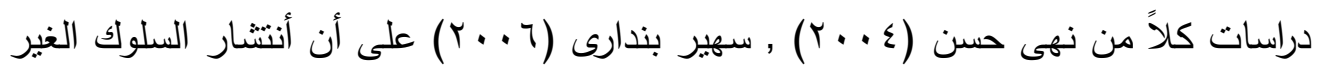
واعى فى التعامل مع الموارد البيئية لدى الريفيات وسوء التصرف فى المخلفات المنزلية وعدم صيانة المرافق بالاضافة الى استخدام المصادر التقليدية فى انتاج الطاقة مما يؤثر بصورة مباشرة أو غير مباشرة على تلوث البيئة . 
عدد خاص من مجلة "بحوث في العلوم والفنون النوعيه" التوديه

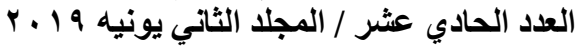

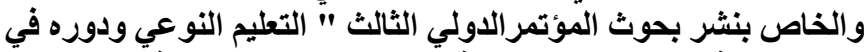

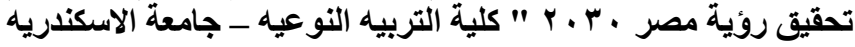

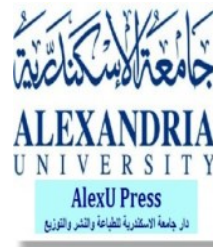

جدول (IV) تحليل التباين للفروق في متوسطات سياسات الإلتزام البيئى لرية الأسرة تبعاً لمتغير مستوى تعليم رية الأسرة (ن= (Y)

\begin{tabular}{|c|c|c|c|c|c|}
\hline الالالة & قيمة (ف) & الدرجية & متوسط المربعات & مجموع المربعات & مستوى تعليم ربة الأسرة \\
\hline \multicolumn{6}{|c|}{ سباسة التخفيض و الترشيل } \\
\hline \multirow{3}{*}{0.01} & \multirow{3}{*}{54.121} & $\overline{2}$ & 1547.031 & $\overline{3094.062}$ & بين المجمو عات \\
\hline & & 216 & 28.585 & 6174.266 & داخل المجمو عات \\
\hline & & 218 & & 9268.328 & المجموع \\
\hline \multicolumn{6}{|c|}{ سياسةة السلامة البيئية } \\
\hline \multirow{3}{*}{0.01} & \multirow{3}{*}{31.878} & $\overline{2}$ & 1456.319 & 2912.637 & بين المجموعات \\
\hline & & 216 & 45.685 & 9867.907 & داخل المجموعات \\
\hline & & 218 & & 12780.544 & المجموع \\
\hline \multicolumn{6}{|c|}{ سياسة إعادة التذوير } \\
\hline \multirow{3}{*}{ - م 0.01 دال } & \multirow{2}{*}{45.140} & $\overline{2}$ & 1517.553 & $\overline{3035.106}$ & بين المجموعات \\
\hline & & 216 & 33.619 & 7261.657 & داخل المجموعات \\
\hline & & 218 & & 10296.763 & المجموع \\
\hline \multicolumn{6}{|c|}{ سياسة الإصلاح و الصياتة } \\
\hline \multirow{3}{*}{ - م 0.01 دال } & \multirow{2}{*}{61.937} & $\overline{2}$ & 1394.686 & 2789.372 & بين المجموعات \\
\hline & & 216 & 22.518 & 4863.854 & داخل المجموعات \\
\hline & & 218 & & $\overline{7653.226}$ & المجموع \\
\hline \multicolumn{6}{|c|}{ سياسات الإلتزام البيئي ككل } \\
\hline \multirow{3}{*}{0.01} & \multirow{3}{*}{$\mathbf{5 5 . 8 5 0}$} & 2 & 1495.561 & 2991.122 & بين المجموعات \\
\hline & & 216 & 26.778 & 5784.130 & داخل المجموعات \\
\hline & & 218 & & 8775.252 & المجموع \\
\hline
\end{tabular}

يتضح من جدول (V) وجود فروق ذات دلالة إحصائية في سياسات الإلتزام البيئى لربة الأسرة تبعاً لمتغير مستوى التعليم ، ولبيان اتجاه دلالة الفروق تم تطبيق اختبار (LSD) للمقارنات المتعددة وجدول (1 (1) يوضح ذلك .

؛ أشارع محمد أمين شهيب - مصطفى كامل ـ الاسكندريه ـ مصر تليفون : 203/5454313

Alexandria - Egypt, Tel. : 203/5454313 - 203/5442776 Fax :203/5442776 E-mail : journal.edusp@alexu.edu.eg Web site: RSSA.edusp@lexu.edu.eg 
جدول (1 1 ) دلالة الفروق في متوسطات سياسات الإلتزام البيئى لرية الأسرة تبعاً لمتغير مستوى

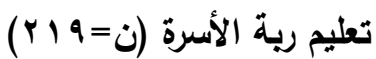

\begin{tabular}{|c|c|c|c|}
\hline \multicolumn{4}{|c|}{ سياسة التخفيض والترشيد } \\
\hline عالي (م = 72.202) & متوسط (م = 58.544) & منخفض (م = 41.321) & المستوي التعليمي \\
\hline & & - & منخفض \\
\hline & - & $* * 17.223$ & متوسط \\
\hline- & $* * 13.658$ & $* * 30.881$ & مرتفع \\
\hline \multicolumn{4}{|c|}{ سياسة السلامة البيئية } \\
\hline \multirow[t]{3}{*}{ عالي ( م = 101.536) } & متوسط (م = 99.483) & منخفض (م = 72.251) & المستوي التعليمي \\
\hline & & - & منخفض \\
\hline & - & $* * 27.232$ & متوسط \\
\hline- & *2.053 & $* * 29.285$ & مرتفع \\
\hline \multicolumn{4}{|c|}{ سياسة إعادة التدوير } \\
\hline \multirow[t]{3}{*}{ عالي (م = 60.638) } & متوسط (م = 48.222) & منخفض (م = 35.520) & المستوي التعليمي \\
\hline & & - & منخفض \\
\hline & - & $* * 12.702$ & متوسط \\
\hline \multirow[t]{2}{*}{-} & $* * 12.416$ & $* * 25.118$ & مرتفع \\
\hline & \multicolumn{3}{|c|}{ سياسة الإصلاح والصياتة } \\
\hline \multirow[t]{3}{*}{ عالي (م = 44.442) } & متوسط (م = 35.527) & منخفض (م = 22.638) & المستوي التعليمي \\
\hline & & - & منخفض \\
\hline & - & $* * 12.889$ & متوسط \\
\hline \multirow[t]{2}{*}{-} & $* * 8.915$ & $* * 21.804$ & مرتفع \\
\hline & م البيئي ككل & سياسLات & \\
\hline \multirow[t]{3}{*}{ عالي (م = 278.818) } & متوسط (م = 241.776) & منخفض (م = 171.730) & المستوي التعليمي \\
\hline & & - & منخفض \\
\hline & - & $* * 70.046$ & متوسط \\
\hline- & $* * 37.042$ & $* * 107.088$ & مرتفع \\
\hline
\end{tabular}

يتضح من جدول (1/1) وجود فروق ذات دلالة إحصائية في منوسطات سياسات الإلنزام البيئى لربة الأسرة تبعاً لمتغير المستوى التعليهى ، حيث كانت دالة لصالح المستوى التعليمى لهی

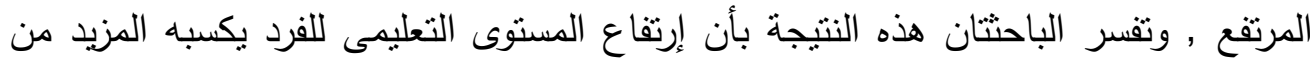
الوعى والثقافة وإدارة الأمور بحكمة وإيجابية ويجعله أكثر قدرة على التعامل مع البيئة إنهان المحيطة به , مما يفسر تفوق ربة الأسرة ذات المستوى التعليمى المرتقع فى سياسات الالتزام 


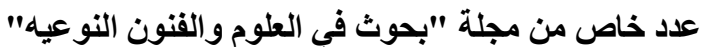

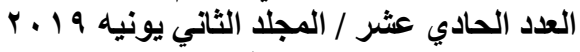

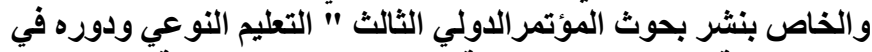

تحقيق روئة مصر ·. . . " " كلية التربيه النوعيه - جامعة الاسكندرية

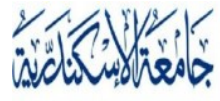

ALEXANDRIA

U N I VER S I T Y

البيئى بمحاورها عن ربة الأسرة ذات المستوى التعليمى الأقل , والذى يجعلها أكثر وعياً بقيمة

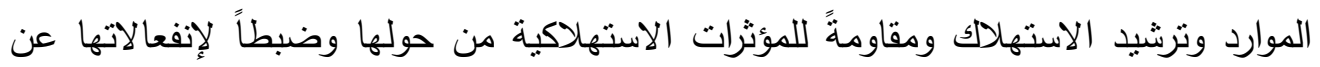

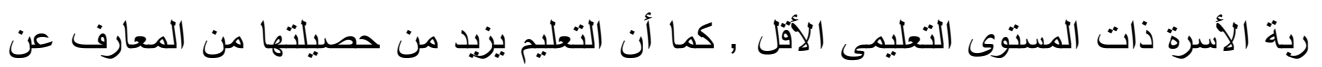

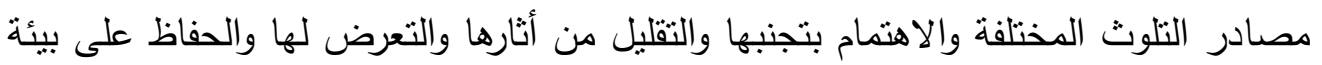
منزلها خالية من التلوث قدر الإمكان , ويزيد التعليم من فرصها فى الاطلاع والتعرف على منى

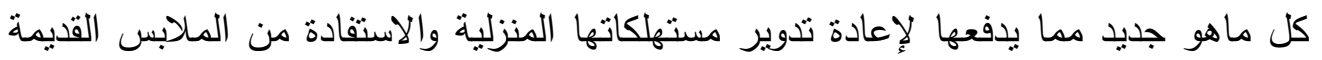
لديها فى انتاج منتجات جديدة , وتغير شكل ما تبقى لديها من أطعمه فى إعداد أطباق جديدة

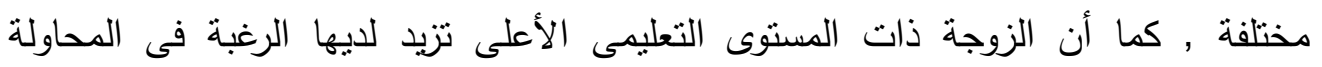

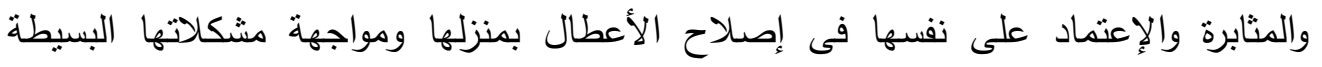

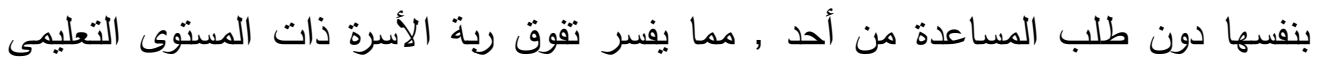
الأعلى فيما يتعلق بسياسات الالتزام البيئى بمحاورها , وتختلف هذه النتيجه مع ما أنثارت اليه

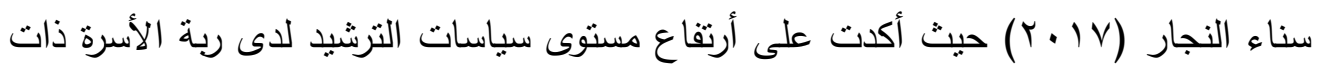

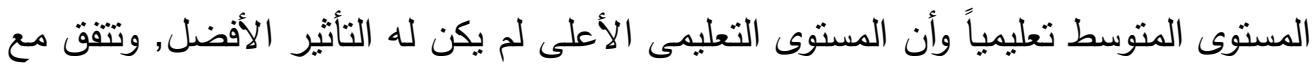

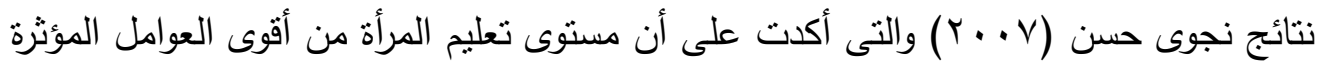

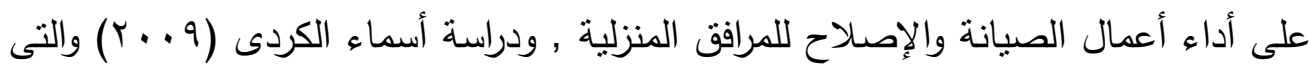

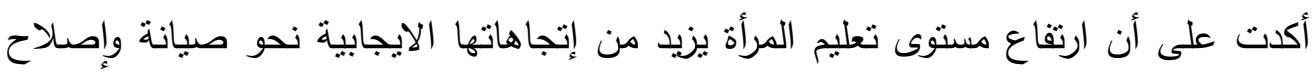

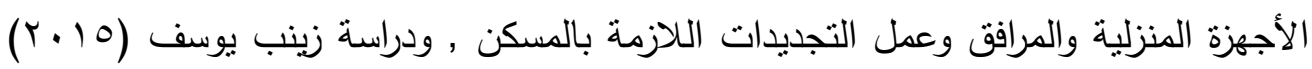
والتى أثنارت الى أن ارتفاع المستوى التعليمى للزوجة يؤدى الى اتباع استراتيجيات ترشيد

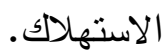


جدول (9 1 ) تحليل التباين للفروق في متوسطات سياسات الإلتزام البيئى لرية الأسرة تبعاً لمتغير مدة الزواج $(Y) 9=\dot{0})$

\begin{tabular}{|c|c|c|c|c|c|}
\hline 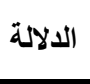 & قيمة (ف) & الحرية & متوسط المربعات & مجموع المربعات & مدة الزواج \\
\hline \multicolumn{6}{|c|}{ سياسة التخفيض و الترشيد } \\
\hline \multirow{3}{*}{$\begin{array}{c}\mathbf{0 . 0 1} \\
\end{array}$} & \multirow{2}{*}{35.994} & 2 & 1478.409 & 2956.817 & بين المجموعات \\
\hline & & 216 & 41.074 & 8872.050 & داخل المجموعات \\
\hline & & 218 & & 11828.867 & المجموع \\
\hline \multicolumn{6}{|c|}{ سياسة السلامة البيئية } \\
\hline \multirow{3}{*}{$\begin{array}{c}\mathbf{0 . 0 1} \\
\text { دال }\end{array}$} & \multirow{2}{*}{38.860} & 2 & 1491.951 & 2983.902 & بين المجموعات \\
\hline & & 216 & 38.393 & 8292.948 & داخل المجموعات \\
\hline & & 218 & & 11276.850 & المجموع \\
\hline \multicolumn{6}{|c|}{ سياسة إعادة التذوير } \\
\hline \multirow{3}{*}{$\begin{array}{c}\mathbf{0 . 0 1} \\
\text { دال }\end{array}$} & \multirow{2}{*}{25.807} & 2 & 1416.053 & 2832.107 & بين المجموعات \\
\hline & & 216 & $\mathbf{5 4 . 8 7 0}$ & 11851.989 & داخل المجموعات \\
\hline & & 218 & & 14684.096 & المجموع \\
\hline \multicolumn{6}{|c|}{ سياسة الإصلاح و الصيانة } \\
\hline \multirow{3}{*}{$\begin{array}{c}\mathbf{0 . 0 1} \\
\text { دال }\end{array}$} & \multirow{2}{*}{34.251} & 2 & 1483.266 & 2966.533 & بين المجموعات \\
\hline & & 216 & 43.305 & 9353.986 & داخل المجموعات \\
\hline & & 218 & & 12320.519 & المجموع \\
\hline \multicolumn{6}{|c|}{ سياسات الإلتزام البيئي ككل } \\
\hline \multirow{3}{*}{$\begin{array}{c}0.01 \\
\text { دال }\end{array}$} & \multirow{2}{*}{48.896} & 2 & 1474.825 & 2949.649 & بين المجموعات \\
\hline & & 216 & 30.163 & 6515.159 & داخل المجموعات \\
\hline & & 218 & & 9464.808 & المجموع \\
\hline
\end{tabular}

بتضح من جدول (9 (1) وجود فروق ذات دلالة إحصائية في سياسات الإلتزام البيئى لربة الأسرة تبعاً لمتغير مدة الزواج ، ولبيان اتجاه دلالة الفروق تم تطبيق اختبار (LSD) للمقارنات المتعددة وجدول

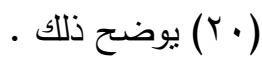

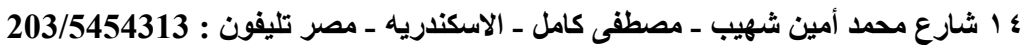

Alexandria - Egypt, Tel. : 203/5454313 - 203/5442776 Fax :203/5442776 E-mail : journal.edusp@alexu.edu.eg Web site: RSSA.edusp@lexu.edu.eg 


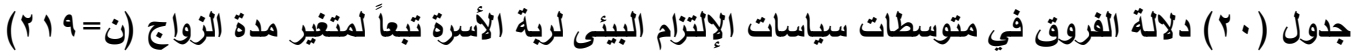

\begin{tabular}{|c|c|c|c|}
\hline \multicolumn{4}{|c|}{ سياسة التخفيض والترشيد } \\
\hline أكثر من ه سنة م م= & من · r لاقل من •r سنه م = 41.27 & أقلّ من ·r سنة م= & 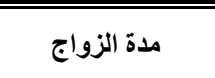 \\
\hline & & - & أقل من · r سنة \\
\hline & - & $* 2.240$ & من • ب لاقل من هץ \\
\hline- & $* * 21.280$ & $* * 23.520$ & أكثر من •r سنة \\
\hline \multicolumn{4}{|c|}{ سياسة السلامة البيئية } \\
\hline أكثر من هr سنة م = & 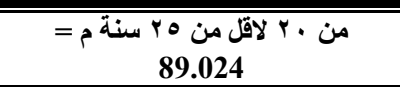 & أَقل من · r سنة م = & مدة الزواج \\
\hline & & - & أقل من · r سنة \\
\hline & - & $* * 18.671$ & من • r لاقل من هr \\
\hline- & $* 2.914$ & $* * 21.585$ & أكثر من هب سنة \\
\hline \multicolumn{4}{|c|}{ سياسة إعادة التدوير } \\
\hline أكثر من •ץ سنة م = 59.21 & من · r لاقل من •r سنة م = 58.88 & أقلّ من ·r سنة م = & مدة الزواج \\
\hline & & - & أقل من · ب سنة \\
\hline & - & $* * 28.472$ & من · r لاقل من هץ \\
\hline- & 0.330 & $* * \mathbf{2 8 . 8 0 2}$ & أكثر من •r سنة \\
\hline \multicolumn{4}{|c|}{ سياسة الإصلاح والصيانة } \\
\hline أكثر من •r سنة م = 39.11 & من · r لاقل من هr سنة م = 30.26 & أقل من ·r سنة م = & مدة الزواج \\
\hline & & - & أقلّ من · r سنة \\
\hline & - & *2.158 & من · r لاقل من •r \\
\hline- & $* * 8.849$ & $* * 11.007$ & أكثر من هY سنة \\
\hline \multicolumn{4}{|c|}{ سياسات الإلتزام البيئي ككل } \\
\hline \multirow[t]{3}{*}{ أكثر من •r سنة م = } & من · r لاقل من • س سن م = 219.45 & أقل من ·r سنة م = & مدة الزواج \\
\hline & & - & أقل من · r سنة \\
\hline & - & $* * 51.541$ & من · r لاقل من •r \\
\hline- & $* * 33.373$ & $* * 84.914$ & أكثر من ه سنة \\
\hline
\end{tabular}

يتضح من جدول (·r) وجود فروق ذات دلالة إحصائية في متوسطات سياسات الإلنزام البيئى لربة الأسرة تبعاً لمتغير مدة الزواج ، حيث كانت دالة لصالح الددة الأطول , ويمكن تقسير ذللك بأن طول مدة الزواج تكسب ربة الأسرة المزيد من الخبرة والمعرفة بسبب زيادة

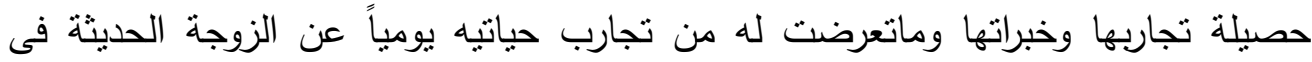


الزواج والتى مازالت تحاول أن تكتسب الخبرة فى التعامل مع ظروفها المعيشية , مما يؤثر بالإيجاب على إكتسابها المزيد من الوعى الاستهلاكى وترشيد استهلاكها وتقنين استخدام مالديها من موارد والاستفادة المتلى منها وإعادة تدوير مالديها من مستهلكات وتغير شكلها

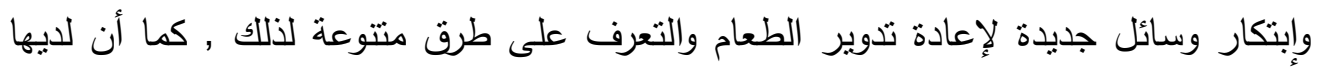
من الخبرة قدر أكبر فيما يتعلق بالسلامة البيئية ومعرفة المصادر المتتوعة للتلوث داخل فلثل

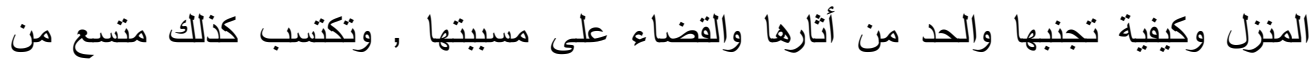
الخبرات فى إصلاح وصيانة الأعطال داخل منزلها والتعامل معها بسبب تعدد المواقف التى وهى واجهتها خلال مدة زواجها الطويلة مما يفسر إتباعها لسياسات الالتزام البيئى داخل منزلها

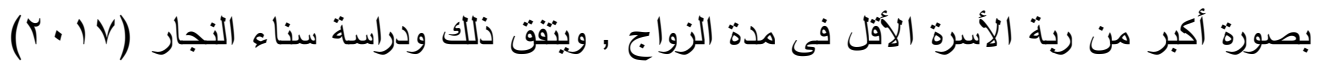
والتى أكدت على وجود فروق فى السياسات الاستهلاكية لربة الاسرة لصالح السن الأكبر حيث تزداد معارفها ومعلوماتها تجاه الاستهلاك ومن ثم استخدام تلك المعارف استخداماً فعالاً يدفعها لترشيد استهلاكها , وفى هذا السياق نتير الباحتثان الى أثز مدة الزواج والتى تؤثنز

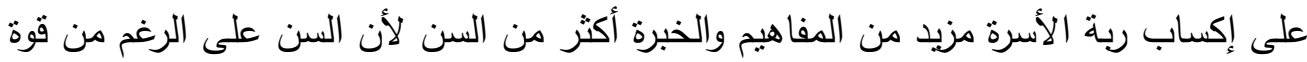

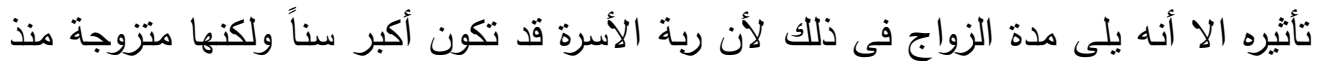

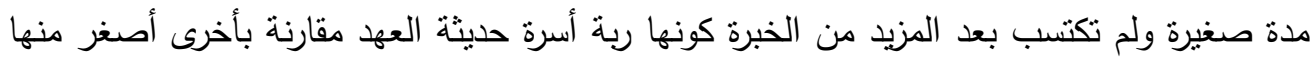
فى السن ولكنها متزوجة منذ فترة أطول مما يزيد من رصيدها من المهارات الإدارية النى تثكل

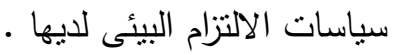


عدد خاص من مجلة "بحوث في العلوم والقنون النوعيه" العزيه

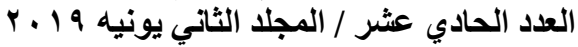

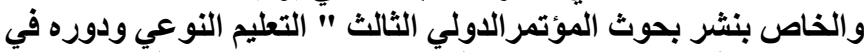

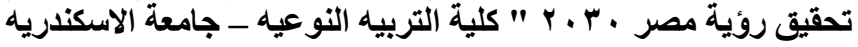

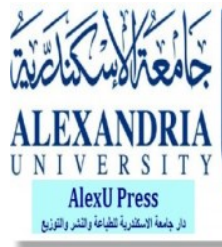

جدول (Y Y Y تحليل التباين للفروق في متوسطات سياسات الإلتزام البيئى لرية الأسرة تبعاً لمتغير مستوى الاخل الثهرى للأسرة (ن= 9 (Y)

\begin{tabular}{|c|c|c|c|c|c|}
\hline الالالة & قيمة (ف) & درجات الحرية & متوسط المربعات & مجموع المربعات & مستوى الاخل الشهرى \\
\hline \multicolumn{6}{|c|}{ سياسة التخفيض والترشيد } \\
\hline \multirow{2}{*}{ ( 0.01 دال } & \multirow{2}{*}{69.574} & 2 & 1585.139 & 3170.278 & بين المجموعات \\
\hline & & 216 & 22.784 & 4921.265 & داخل المجموعات \\
\hline & & 218 & & 8091.543 & المجموع \\
\hline \multicolumn{6}{|c|}{ سياسة السلامة البيئية } \\
\hline \multirow{3}{*}{ - 0.01 دال } & \multirow{2}{*}{49.135} & 2 & 1531.535 & 3063.071 & بين المجموعات \\
\hline & & 216 & 31.170 & 6732.738 & داخل المجموعات \\
\hline & & 218 & & 9795.809 & المجموع \\
\hline \multicolumn{6}{|c|}{ سياسة إعادة التدوير } \\
\hline \multirow{2}{*}{0.010} & \multirow{2}{*}{51.444} & 2 & 1482.844 & 2965.687 & بين المجموعات \\
\hline & & 216 & 28.824 & 6226.068 & داخل المجموعات \\
\hline & & 218 & & 9191.755 & المجموع \\
\hline \multicolumn{6}{|c|}{ سياسة الإصلاح والصيانة } \\
\hline \multirow{2}{*}{ ( 0.01 دال } & \multirow{2}{*}{37.111} & 2 & 1497.811 & 2995.622 & بين المجموعات \\
\hline & & 216 & 40.360 & 8717.730 & داخل المجموعات \\
\hline & & 218 & & 11713.352 & المجموع \\
\hline \multicolumn{6}{|c|}{ سياسات الإلتزام البيئي ككل } \\
\hline \multirow{3}{*}{ - 0.01 دال } & \multirow{2}{*}{64.635} & 2 & 1401.649 & 2803.299 & بين المجموعات \\
\hline & & 216 & 21.686 & 4684.085 & داخل المجموعات \\
\hline & & 218 & & 7487.384 & المجموع \\
\hline
\end{tabular}

يتضح من جدول (Y) وجود فروق ذات دلالة إحصائية في سياسات الإلتزام البيئى لربة الأسرة تبعاً لمتغير مستوى الدخل الثهرى للأسرة ، ولبيان اتجاه دلالة الفروق تم تطبيق اختبار (LSD) 


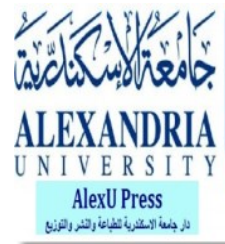

جدول (Y Y ) دلالة الفروق في متوسطات سياسات الإلتزام البيئى لرية الأسرة تبعاً لمتغير مستوى

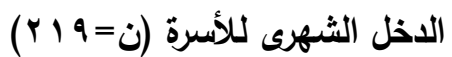

\begin{tabular}{|c|c|c|c|}
\hline \multicolumn{4}{|c|}{ سياسة التخفيض والترشيل } \\
\hline 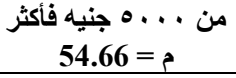 & 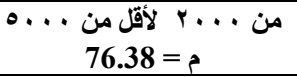 & أقل من م 85.85 & الاخل الثهري \\
\hline & & - & أقل من . . . ب جنيه \\
\hline & - & $* * 9.473$ & 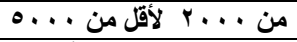 \\
\hline- & $* * 21.718$ & $* * 31.191$ & من . . • جنيه فأكثر \\
\hline \multicolumn{4}{|c|}{ سياسة السلامة البيئية } \\
\hline 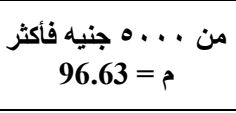 & 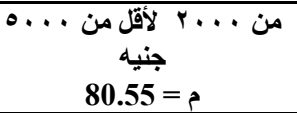 & أقل من = . . . ب جنيه & الاخل الشهري \\
\hline & & - & أقل من . . . ب جنيه \\
\hline & - & $* * 23.354$ & 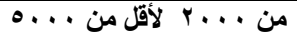 \\
\hline- & $* * 16.081$ & $* * 39.435$ & من . . . • جنيه فأكثر \\
\hline \multicolumn{4}{|c|}{ سياسة إعادة التدوير } \\
\hline \multirow[t]{3}{*}{ 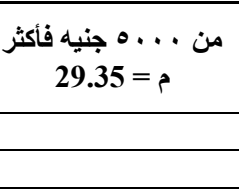 } & 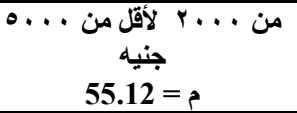 & أقل من = . . . ج جنيه & الاخل الشهري \\
\hline & & - & أقل من . . . ب جنيه \\
\hline & - & $* * 8.622$ & 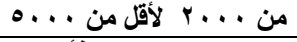 \\
\hline- & $* * 25.776$ & $* * 34.398$ & من · ... ج جنيه فأكثر \\
\hline \multicolumn{4}{|c|}{ سياسة الإصلاح والصيانة } \\
\hline \multirow[t]{3}{*}{ من م = . . . جنيه فأكثر } & 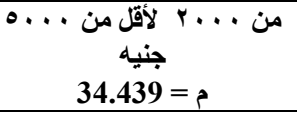 & أقل من = . . . جنيه & الاخل الثهري \\
\hline & & - & أقل من . . . ب جنيه \\
\hline & - & $* * 11.866$ & 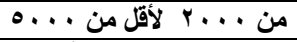 \\
\hline- & $* 2.415$ & $* * 14.281$ & من . . • جنيه فأكثر \\
\hline \multicolumn{4}{|c|}{ سياسات الإلتزام البيئي ككل } \\
\hline \multirow[t]{3}{*}{ من م = . . م جنيه فأكثر } & 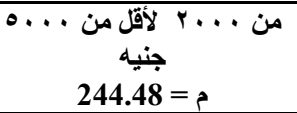 & أقل من = . . . جنيه & الاخل الشهري \\
\hline & & - & أقل من . . . ب جنيه \\
\hline & - & $* * 10.637$ & 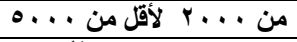 \\
\hline- & $* * 31.813$ & $* * 42.450$ & من · . . • جنيه فأكثر \\
\hline
\end{tabular}

؛ 1 شارع محمد أمين شهيب ـ مصطفى كامل ـ الاسكندريه ـ مصر تليفون : 203/5454313 : 203/5454313

Alexandria - Egypt, Tel. : 203/5454313 - 203/5442776 Fax :203/5442776 E-mail : journal.edusp@alexu.edu.eg Web site: RSSA.edusp@lexu.edu.eg 
عدد خاص من مجلة "بحوث في العلوم والقنون النوعيه" العزيه

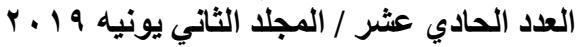

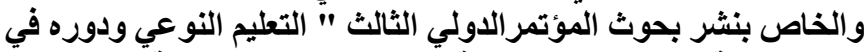

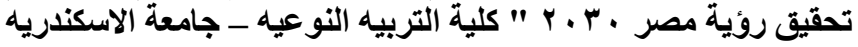

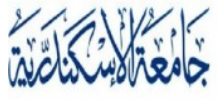

جدول (r r د دلالة الفروق في متوسطات مجالات الخبرات البيئية للأبناء فى ضوء التتمية

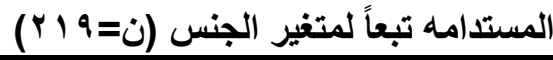

\begin{tabular}{|c|c|c|c|c|c|c|}
\hline 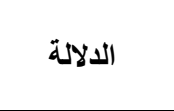 & قيمة (ت ) & الدرية & 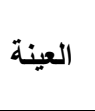 & الالانحراف & الحسابي & جنس الإبن \\
\hline \multicolumn{7}{|c|}{ الخبرة فى الاستفادة من الطاقة المتجددة } \\
\hline \multirow{2}{*}{ لصالح الإناث 0.01 لداث } & \multirow{2}{*}{20.527} & \multirow{2}{*}{217} & 88 & 1.328 & 18.861 & ذكور \\
\hline & & & 131 & 3.624 & 40.333 & إناث \\
\hline \multicolumn{7}{|c|}{ خبرة إدارة الموارد البيئية } \\
\hline \multirow{2}{*}{ لصالح الإناث 0.01 لداث } & \multirow{2}{*}{9.210} & \multirow{2}{*}{217} & 88 & 2.071 & 25.182 & ذكور \\
\hline & & & 131 & 3.385 & 34.200 & إناث \\
\hline \multicolumn{7}{|c|}{ خبرة مواجهة المشكلات البيئية } \\
\hline \multirow{2}{*}{ لصالح الإناث } & \multirow{2}{*}{23.329} & \multirow{2}{*}{217} & 88 & 3.881 & 44.419 & ذكور \\
\hline & & & 131 & 6.302 & 68.426 & إناث \\
\hline \multicolumn{7}{|c|}{ الخبرات البيئية للأبناء ككل } \\
\hline \multirow{2}{*}{ لصالح عند الإناث } & \multirow{2}{*}{39.657} & \multirow{2}{*}{217} & 88 & 7.845 & 88.462 & ذكور \\
\hline & & & 131 & 9.210 & 142.959 & إناث \\
\hline
\end{tabular}

يتضح من جدول (Tr) وجود فروق ذات دلالة إحصائية في مجالات الخبرات البيئية للأبناء

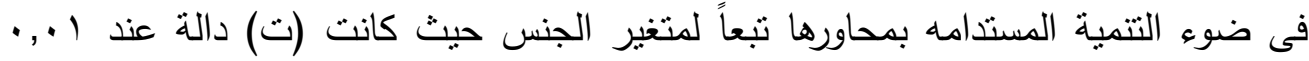
لصالح الإناث فى كافة مجالات الخبرات البيئية , ويمكن تفسير ذلك بأن الإناث بفعل طبيعة تكوينهم وتأثير التربية والتنشئة وإقترابهم من أمهاتهم وقضاء وقت أطول داخل المنزل وإحتكاكه بالتجارب المنزلية ومشاهدتهم بل ومشاركتهم للممارسات البيئية للأم داخل المنزل

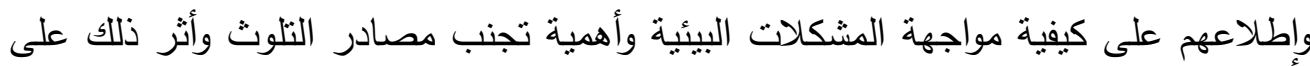
تشكيل خبراتهم فى إدارة مواردهم ومواجهة المشكلات البيئية , وكيف يمكن الاستفادة من

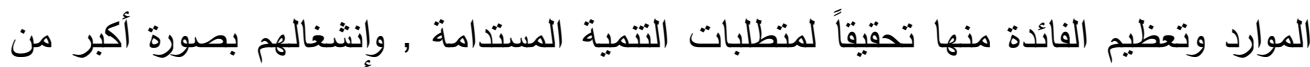

ك ا شارع محمد أمين شهيب - مصطفى كامل ـ الاسكندريه ـ مصر تليفون : 203/5454313

Alexandria - Egypt, Tel. : 203/5454313 - 203/5442776 Fax :203/5442776

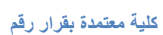
E-mail : journal.edusp@alexu.edu.eg Web site: RSSA.edusp@lexu.edu.eg 
الذكور بكل ما يتعلق بقضايا البيئة المحيطة مما يكسبهن المزيد من الخبرات البيئية بمجالاتها المختلفة عن الذكور ويسهم فى نشكيل هذه الخبرات بفاعلية , ويتفق ذلك ودراسة جيلان

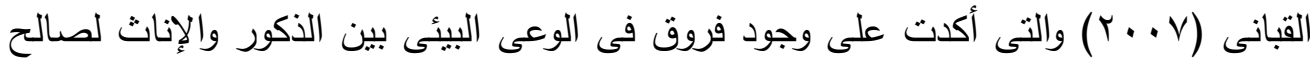

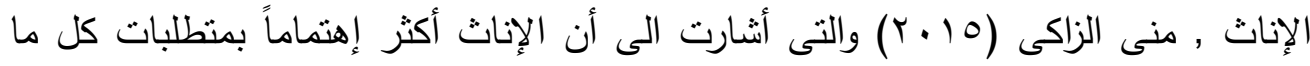

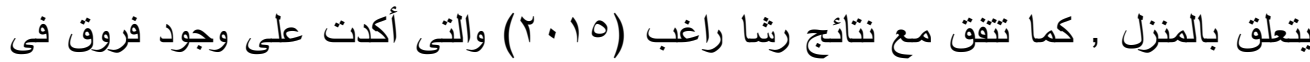
إكتساب خبرة حسن استخدام الموارد البيئية وخبرة الوعى بالمشكلات البيئية والتلوث لصات لصالح

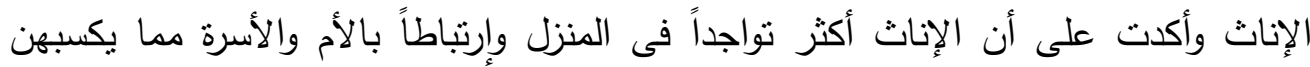
المزيد من الخبرة فى كيفية العناية والاستخدام الجيد للموارد والبيئة من ماء وكهرباء وغاز وخدمات متاحة بخلاف الذكور , وتختلف هذه النتيجه مع دراسة مهجة مسلم وأخرون

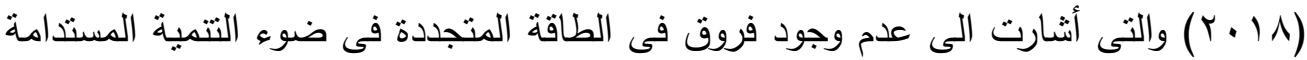

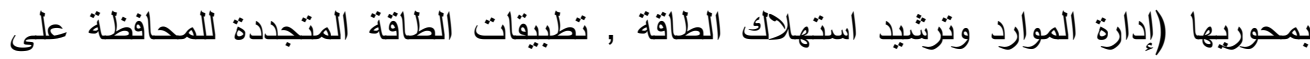
البيئة الداخلية والخارجية للمسكن) بين الذكور والإناث , ودراسة هبه شعيب (• • • (ب) فى عدم

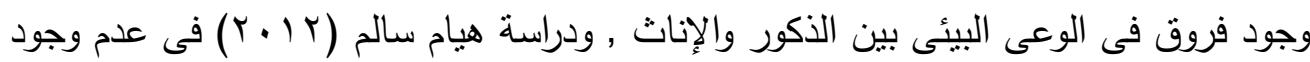

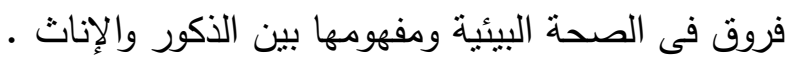


عدد خاص من مجلة "بحوث في العلوم والفنون النوعيه"

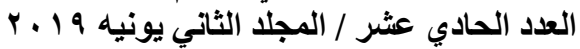

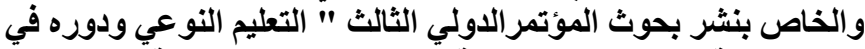

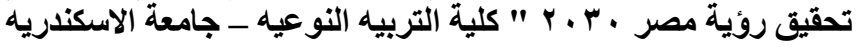

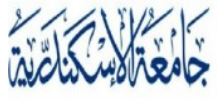

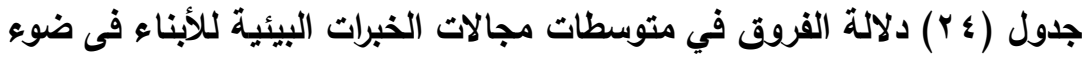

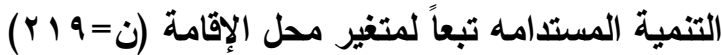

\begin{tabular}{|c|c|c|c|c|c|c|}
\hline 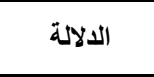 & قيمة (ت) & درجات الحرية & 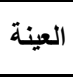 & الالمعرافياري & المستوسطي المسبي & محل الإقامة \\
\hline \multicolumn{7}{|c|}{ الخبرة في الاستفادة من الطاقة المتجددة } \\
\hline \multirow{2}{*}{ لصالح عند 0.01} & \multirow{2}{*}{13.300} & \multirow{2}{*}{217} & 143 & 4.251 & 42.638 & حضر \\
\hline & & & 76 & 2.619 & 27.716 & ريف \\
\hline \multicolumn{7}{|c|}{ خبرة إدارة الموارد البيئية } \\
\hline \multirow{2}{*}{ لصالح عند 0.01} & \multirow{2}{*}{13.629} & \multirow{2}{*}{217} & 143 & 3.254 & 30.849 & حضر \\
\hline & & & 76 & 1.119 & 16.674 & ريف \\
\hline \multicolumn{7}{|c|}{ خبرة مواجهة المشكلات البيئية } \\
\hline \multirow{2}{*}{ لصالح الحضد 0.01} & \multirow{2}{*}{14.157} & \multirow{2}{*}{217} & 143 & 7.081 & 71.158 & حضر \\
\hline & & & 76 & 5.220 & 57.321 & ريف \\
\hline \multicolumn{7}{|c|}{ الخبرات البيئية للأبناء ككل } \\
\hline \multirow{2}{*}{ لصالح الحضر 0.01} & \multirow{2}{*}{34.521} & \multirow{2}{*}{217} & 143 & 9.861 & 144.645 & حضر \\
\hline & & & 76 & 8.002 & 101.711 & ريف \\
\hline
\end{tabular}

يتضح من جدول (乏) وجود فروق ذات دلالة إحصائية في مجالات الخبرات البيئية للأبناء

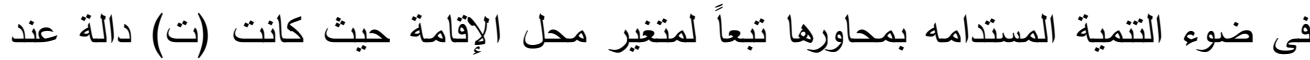
I.,., لصالح الأبناء المقيمن فى الحضر , ويمكن تفسير ذلك بأن مصادر تلقى المعرفة والمعلومات والخبرات تتتوع وتزداد فى الحضر عنها فى الريف كما تزداد فرص الابناء المقيمين فى الحضر فى الاطلاع والتدريب والمعرفة من خلال انتشار المكتبات والمعارض والنوادى ودور الثباب التى تتيح لهم التعرف على كل ماهو جديد عن قرب مثل مفاهيم الطاقة المتجددة والنتمية المستدامة وغيرها وتقل هذه الفرص فى الريف , مما بزيد من فرصة الأبناء المقيمين فى الحضر فى اكتساب مزيد من الخبرات البيئية بمجالاتها المختلفة , ويتفق

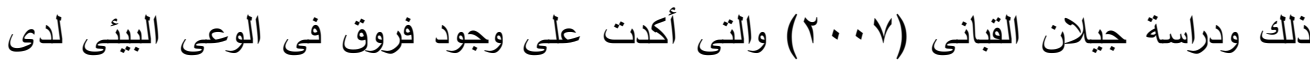

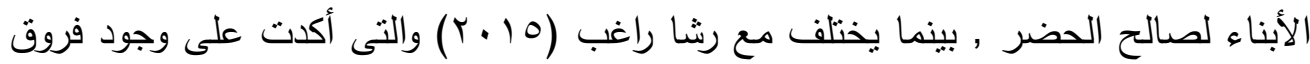

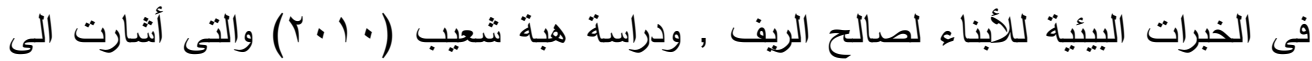
عدم وجود فروق لدى الأبناء بين الريف والحضر • 
عدد خاص من مجلة "بحوث في العلوم والقنون النوعيه" التونيه

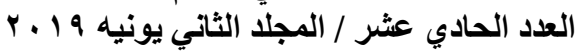

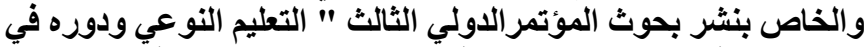

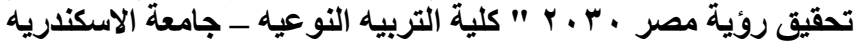

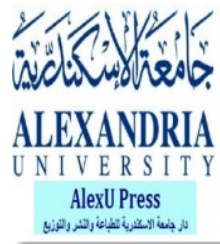

جدول(ه r) تحليل التباين بين الأبناء فى الخبرات البيئية فى ضوء التنمية المستدامه تبعاً

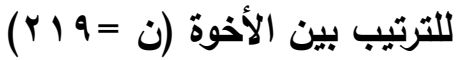

\begin{tabular}{|c|c|c|c|c|c|}
\hline الالاكة & قيمة (ف) & درجات الحرية & متوسط المربعات & مجموع المربعات & الترتيب بين الأخوة \\
\hline \multicolumn{6}{|c|}{ الخبرة فى الاستفادة من الطاقة المتجددة } \\
\hline \multirow{3}{*}{0.01 دال } & \multirow{2}{*}{56.291} & 2 & 1568.004 & 3136.009 & بين المجموعات \\
\hline & & 216 & 27.855 & 6016.754 & داخل المجموعات \\
\hline & & 218 & & 9152.763 & المجموع \\
\hline \multicolumn{6}{|c|}{ خبرة إدارة الموارد البيئية } \\
\hline \multirow{2}{*}{ 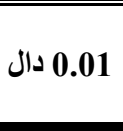 } & \multirow{2}{*}{60.959} & 2 & 1565.466 & 3130.932 & 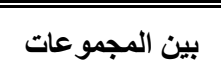 \\
\hline & & 216 & 25.681 & 5547.028 & داخل المجموعات \\
\hline & & 218 & & 8677.960 & 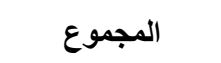 \\
\hline \multicolumn{6}{|c|}{ خبرة مواجهة المشكلات البيئية } \\
\hline \multirow{3}{*}{ 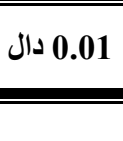 } & \multirow{2}{*}{29.866} & 2 & 1444.147 & 2888.293 & بين المجموعات \\
\hline & & 216 & 48.353 & 10444.334 & داخل المجموعات \\
\hline & & 218 & & 13332.627 & المجموع \\
\hline \multicolumn{6}{|c|}{ الخبرات البيئية للأبناء ككل } \\
\hline \multirow{3}{*}{ 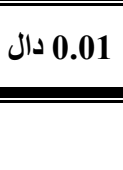 } & \multirow{2}{*}{27.641} & 2 & 1429.395 & 2858.790 & بين المجموعات \\
\hline & & 216 & 51.712 & 11169.889 & داخل المجموعات \\
\hline & & 218 & & 14028.679 & المجموع \\
\hline
\end{tabular}

بتضح من جدول (Y0) وجود تباين دال إحصائياً فى مجالات الخبرات البيئية للأبناء فى ضوء التتمية المستدامه بمحاورها عند مستوى (1 +., ·) تبعاً للترتيب بين الأخوة وللتعرف على بلى إتجاه دلالة الفروق ، تم تطبيق إختبار L.S.D للمقارنات المتعددة كما يتضح من جدول (†T). 
عدد خاص من مجلة "بحوث في العلوم والقنون النوعيه" العزيه

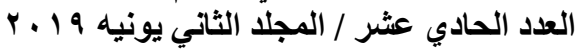

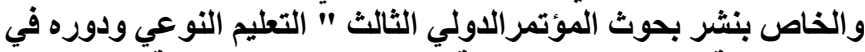

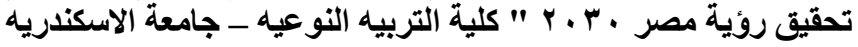

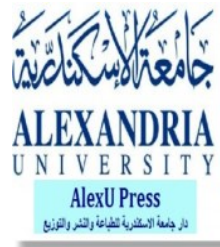

جدول(Y ج) دلالة الفروق بين الأبناء فى الخبرات البيئية بمحاورها تبعاً للترتيب بين الأخوة (ن =9 I )

\begin{tabular}{|c|c|c|c|}
\hline \multicolumn{4}{|c|}{ الخبرة فى الاستفادة من الطاقة المتجددة } \\
\hline الأخير م = 24.410 & الأوسط م = 35.564 & الأول م = 43.341 & الترتيب بين الإخوة \\
\hline & & - & الأول \\
\hline & - & $* * 7.777$ & الأوسط \\
\hline - & $* * 11.154$ & $* * 18.931$ & الأخير \\
\hline \multicolumn{4}{|c|}{ خبرة إدارة الموارد البيئية } \\
\hline \multirow[t]{3}{*}{ الأخير م = 39.711} & الأوسط م = 40.120 & الأول م = 53.392 & الترتيب بين الإخوة \\
\hline & & - & الأول \\
\hline & - & $* * 13.272$ & الأوسط \\
\hline- & 0.409 & $* * 13.681$ & الأخير \\
\hline \multicolumn{4}{|c|}{ خبرة مواجهة المشكلات البيئية } \\
\hline \multirow[t]{3}{*}{ الأخير م = 15.713} & الأوسط م = 29.442 & الأول م= 22.514 & الترتيب بين الإخوة \\
\hline & & - & الأول \\
\hline & - & $* * 6.928$ & الأوسط \\
\hline- & $* * 13.729$ & $* * 6.801$ & 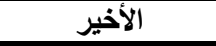 \\
\hline \multicolumn{4}{|c|}{ مجالات الخبرات البيئية للأبناء ككل } \\
\hline \multirow[t]{3}{*}{ الأخير م= 79.834 } & الأوسط م = 111.470 & الأول م = 112.903 & الترتيب بين الإخوة \\
\hline & & - & الأول \\
\hline & - & 1.433 & الأوسط \\
\hline- & $* * 31.636$ & $* * 33.069$ & 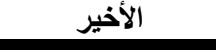 \\
\hline
\end{tabular}

يتضح من جدول (YT) وجود فروق ذات دلالة إحصائية في متوسطات مجالات الخبرات

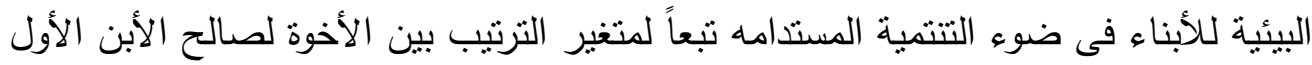

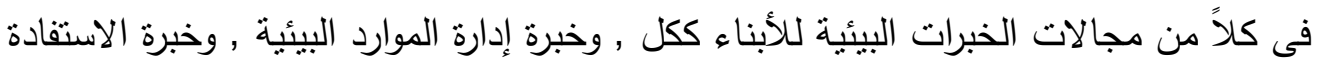
من الطاقة المتجددة , ولصالح الابن الأوسط فى خبرة مواجهة المشكلات البيئية , ويمكن

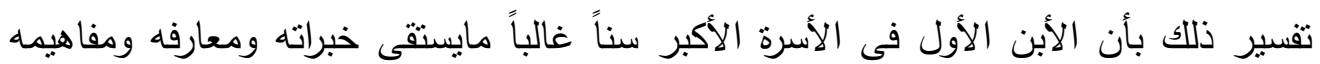

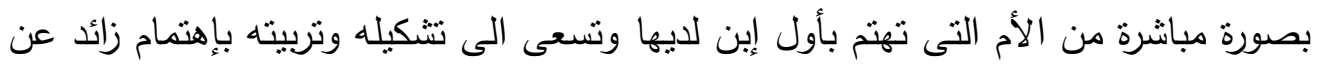

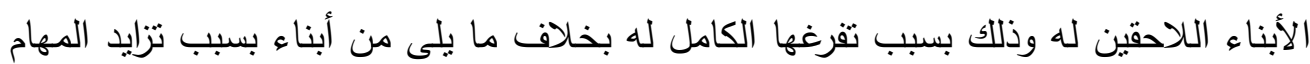

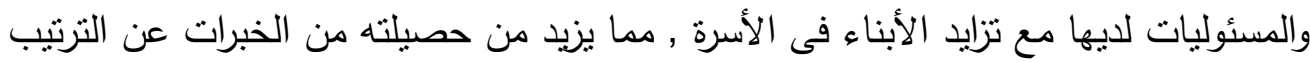

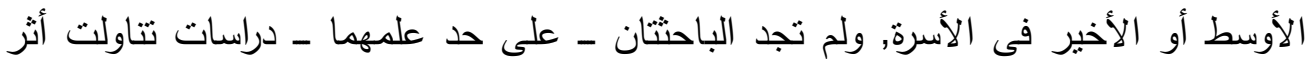

؛ 1 شارع محمد أمين شهيب ـ مصطفى كامل ـ الاسكندريه ـ مصر تليفون : 203/5454313 : 203/5454313

Alexandria - Egypt, Tel. : 203/5454313 - 203/5442776 Fax :203/5442776

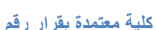

E-mail : journal.edusp@alexu.edu.eg Web site: RSSA.edusp@lexu.edu.eg 
عدد خاص من مجلة "بحوث في العلوم والقنون النوعيه" التونيه

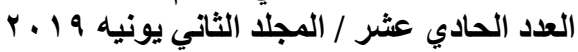

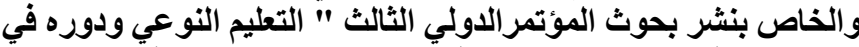

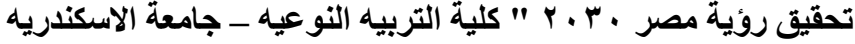

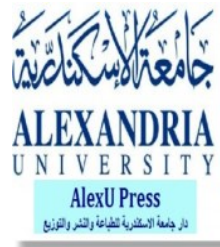

متغير ترتيب الإبن بين الأخوة على محصلته من الخبرات البيئية فى ضوء التتمية المستدامة

جدول(rv) تحليل التباين بين الأبناء فى الخبرات البيئية فى ضوء التتمية المستدامه تبعاً لمستوى

$$
\text { تعليم الأم (ن = ( ) }
$$

\begin{tabular}{|c|c|c|c|c|c|}
\hline الدلالة & قيمة (ف) & الحربة & متوسط المربعات & مجموع المربعات & مستوى تعليم الأم \\
\hline \multicolumn{6}{|c|}{ الخبرة فى الاستفادة من الطاقة المتجددة } \\
\hline \multirow{3}{*}{0.01} & \multirow{2}{*}{68.539} & 2 & 1411.214 & 2822.428 & بين المجموعات \\
\hline & & 216 & 20.590 & 4447.446 & داخل المجموعات \\
\hline & & 218 & & 7269.874 & المجموع \\
\hline \multicolumn{6}{|c|}{ خبرة إدارة الموارد البيئية } \\
\hline \multirow{3}{*}{ 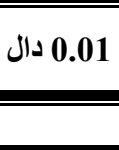 } & \multirow{2}{*}{38.924} & 2 & 1506.297 & 3012.594 & بين المجموعات \\
\hline & & 216 & 38.699 & 8358.957 & داخل المجموعات \\
\hline & & 218 & & 11371.551 & المجموع \\
\hline \multicolumn{6}{|c|}{ خبرة مواجهة المشكلات البيئية } \\
\hline \multirow{2}{*}{0.01} & \multirow{2}{*}{32.647} & 2 & 1474.403 & 2948.807 & بين المجموعات \\
\hline & & 216 & 45.163 & 9755.113 & داخل المجموعات \\
\hline & & 218 & & 12703.920 & المجموع - المع \\
\hline \multicolumn{6}{|c|}{ الخبرات البيئية للأبناء ككل } \\
\hline \multirow{3}{*}{0.01} & \multirow{3}{*}{41.589} & $\overline{2}$ & 1503.694 & $\mathbf{3 0 0 7 . 3 8 7}$ & بين المجموعات \\
\hline & & 216 & 36.156 & 7809.721 & داخل المجموعات \\
\hline & & 218 & & 10817.108 & المجموع \\
\hline
\end{tabular}

يتضح من جدول (YV) وجود تباين دال إحصائياً فى مجالات الخبرات البيئية للأبناء بمحاورها

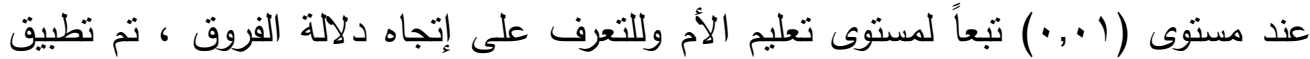

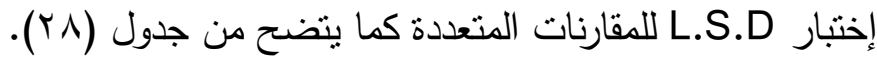


عدد خاص من مجلة "بحوث في العلوم والقنون النوعيه" العزيه

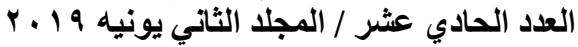

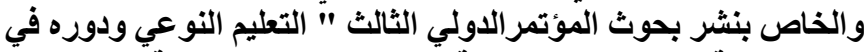

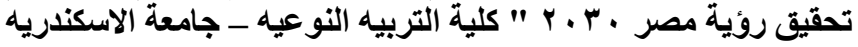

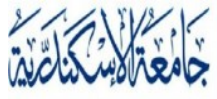

ALEXANDRIA

U N I VER S I T Y

AlexU Press

(i)

جدول(Y^) دلالة الفروق بين الأبناء فى الخبرات البيئية بمحاورها تبعاً لمستوى تعليم الأم

( $r \mid q=\dot{0})$

\begin{tabular}{|c|c|c|c|}
\hline \multicolumn{4}{|c|}{ الخبرة في الاستفادة من الطاقة المتجددة } \\
\hline مرتفع م = 39.396 & متوسط م = 30.250 & منخفض م = 19.754 & المستوي التعليمي للأم \\
\hline & & - & منغفض \\
\hline & - & $* * 10.496$ & متوسط \\
\hline - & $* * 9.146$ & $* * 19.642$ & مرتفع \\
\hline \multicolumn{4}{|c|}{ خبرة إدارة الموارد البيئية } \\
\hline مرتفع م = 32.551 & متوسط م = 25.278 & منخفض م = 23.024 & المستوي التعليمي للأم \\
\hline & & - & منخفض \\
\hline & - & $* 2.254$ & متوسط \\
\hline- & $* * 7.273$ & $* * 9.527$ & مرتفع \\
\hline \multicolumn{4}{|c|}{ خبرة مواجهة المشكلات البيئية } \\
\hline \multirow[t]{3}{*}{ مرتفع م = 63.320 } & متوسط م = 51.582 & منخفض م = 49.221 & المستوي التعليمي للأم \\
\hline & & - & منخفض \\
\hline & - & $* 2.361$ & متوسط \\
\hline- & $* * 11.738$ & $* * 14.099$ & مرتفع \\
\hline \multicolumn{4}{|c|}{ مجالات الخبرات البيئية للأبناء ككل } \\
\hline مرتفع م= 135.267 & متوسط م = 107.110 & منخفض م = 91.999 & المستوي التعليمي للأم \\
\hline & & - & منخفض \\
\hline & - & $* * 15.111$ & متوسط \\
\hline- & $* * 28.157$ & $* * 43.268$ & مرتفع \\
\hline
\end{tabular}

يتضح من جدول (YN) وجود فروق ذات دلالة إحصائية في منوسطات مجالات الخبرات البيئية للأبناء فى ضوء التتمية المستدامه تبعاً لمتغير مستوى تعليم الأم لصالح المستوى الأعلى فى جميع محاور الخبرات البيئية للأبناء والخبرات ككل , وتفسر الباحثنان ذلك بأن ارتفاع المستوى التعليمى للأم والتى تعد بدورها المؤثز الأول على الأبناء ومصدر التربية واستقاء المعلومات والخبرات وكلما زاد مستواها التعليمى والتقافى كلما زادت محصلة ما يمكن أن بستقيه الأبناء من معارف ومفاهيم تشكل خبراتهم وتكسبهم خبرات إيجابية فى حياتهم بصفة عامة ومنها الخبرات البيئية وذلك لأن حصيلة المعلومات والمعارف المتاحة فى الأسرة تزداد مما يتيح الفرصة للأبناء فى تعلم المفاهيم المختلفة والتى تتمى من خبراتهم البيئية وتعلمهم الحفاظ على موارد المياه

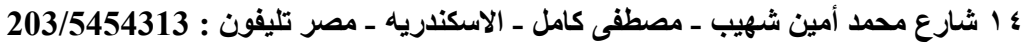

Alexandria - Egypt, Tel. : 203/5454313 - 203/5442776 Fax :203/5442776

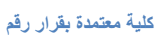

E-mail : journal.edusp@alexu.edu.eg Web site: RSSA.edusp@lexu.edu.eg 
والطاقة والكهرباء ومفاهيم التتمية المستدامة , وأنه كلما زاد مستوى تعليم الأم زاد تبعاً له إهتمامها بقضايا البيئة والتلوث مما يكسب الأبناء مزيد من الخبرات البيئية , ويتفق ذلك ودراسة

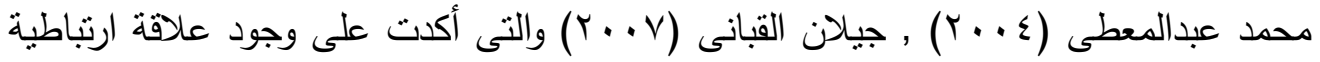
بين الوعى البيئى للأبناء والمستوى التعليمى للوالدين لصالح المستويات الأعلى , ويتفق كذللك

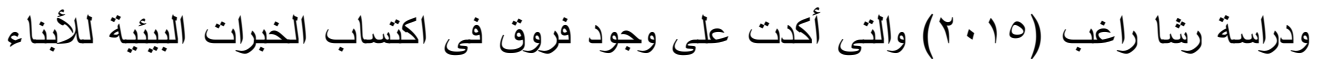

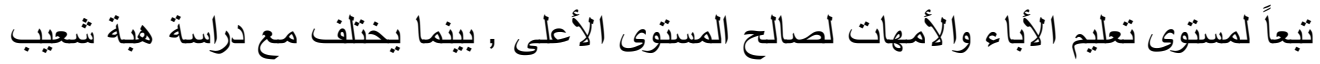

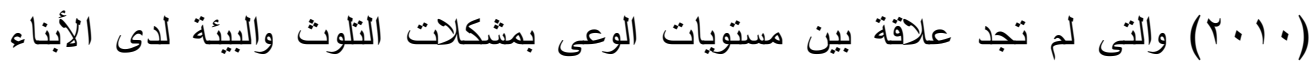

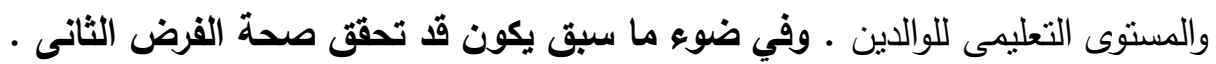

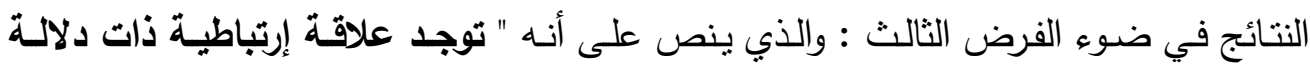
إحصائية بين سياسات الالتزام البيئى لريسة الأسرة بمحاورها (التخفيض والترشيل ، السـلامة

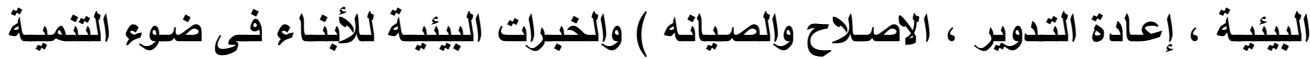
المسـتـامه بمجالاتهـا (الاسـتفادة مـن الطاقـة المتجددة ، إدارة المـوارد البيئيـة ، مواجهـة المشكلات البيئيـة ) " ، وللتحقق مـن صـحة الفرض تم إجـراء معاملات الارتبـاط باستخدام معامـل الارتبـاط "بيرسـون" بين سياسـات الإلتزام البيئى لربـة الأسـرة ومجـالات الخبـرات البيائيـة

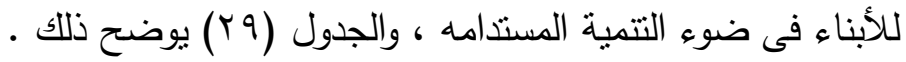


جدول(9 Y) معاملات الإرتباط بين سياسات الإلتزام البيئى لربة الأسرة ومجالات الخبرات البيئية للأبناعفى

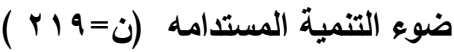

\begin{tabular}{|c|c|c|c|c|}
\hline اللأبناء ككلي البيئية & المشكلات البئية & إدارة الموارد & الطاقة المتجدادة من & سياسات الالتزام البيئى الخبرات البيئية للأبناء \\
\hline$* * 0.729$ & $* * 0.901$ & $* * 0.766$ & $* * 0.814$ & سياسة التخفيض و الترشيد \\
\hline$* * 0.857$ & $* * 0.823$ & *0.605 & $* * 0.734$ & سياسة السلامة البيئية \\
\hline$* * 0.890$ & **0.707 & $* * 0.795$ & *0.629 & سياسة إعادة التدوير \\
\hline$* * 0.751$ & $* 0.640$ & $* * 0.871$ & $* * 0.915$ & سياسة الإصلاح والصيانة \\
\hline$* * 0.808$ & $* * \mathbf{0 . 7 7 7}$ & $* * 0.718$ & $* * 0.845$ & سات الالأ \\
\hline
\end{tabular}

$$
\text { * دال عند مستوى • •, • }
$$

يتضح من جدول (Yq) وجود علاقة ارتباطية موجبة بين سياسات الإلنزام البيئى لربة الأسرة والخبرات البيئية للأبناء فى ضوء التتمية المستدامه عند مستوى دلالة يتراوح بين (0.,. ، ( , • ) , وتفسر الباحثتان هذه النتيجة بأن ربة الأسرة التى تتبع سياسات الإلتزام البيئى من حيث حرصها على ترشيد وتخفيض إستهاكها وتقدير قيمة ما لديها من موارد والمحافظه عليها وإستغلالها الاستخلال الأمثل وحرصها على تتميتها وتعظيم المنفعة منها وإعادة تدوير مستهكاتها وبقاياها المنزلية , والمحافظه على السلامة البيئية لمنزلها وتتجنبها مصادر التلوث المختلفة وحرصها على استخدام المنتجات الصديقة للبيئة بمسكنها , ومحاولة اصلاح أى أعطال بمنزلها وصيانتها , يساهم ذلك فى زيادة رصيدها من الوعى البيئى بمفهومه الثامل وترتفع لديها التقافة البيئية والمفاهيم المتعلقة بتتمية مواردها للمستقبل والحفاظ على البيئة والموارد البيئية ومصادر الطاقة واستبدالها بمصادر نظيفة ورخيصة ودائمة , الأمر الذى كي ينعكس على أبنائها مما يزبد حصيلتهم من الخبرات البيئية بمجالاتها المتتوعة والتى أكتسبوها من ممارسات وسياسات الأم داخل المنزل , ويتقهون مصطلح التتمية المستدامة بل ويؤثز على مايكتسبونه من خبرات منتوعة مثل الاستفادة من الطاقة المتجددة , وكيفية مواجهة المشكلات البيئية , وإدارة الموارد البيئية بصورة تحقق متطلبات التمية المستدامة , وخبراتهم 
البيئية ككل فى ضوء ما تتطلبه عملية التتمية المستدامة فى المجتمع ويتقهمون دورهم

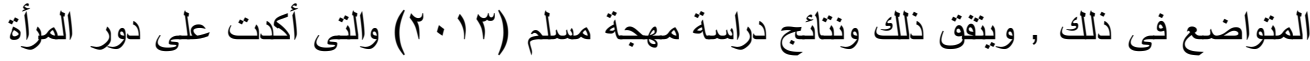
بكونها ربة الأسرة فى الحفاظ على البيئة وتتمية الوعى بها , ودراسة أيمن عكرش وسحر نويصر

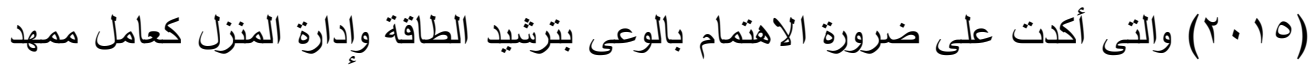
لزيادة مستوى الوعى بممارسات التتمية المستدامة وتعزيز ثقافة ترشيد الموارد وصيانتها لدى

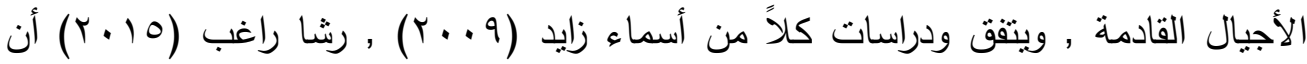

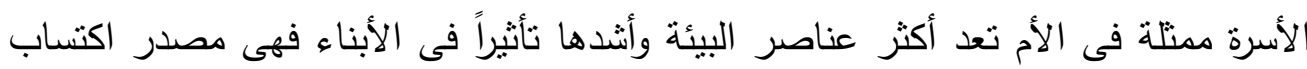

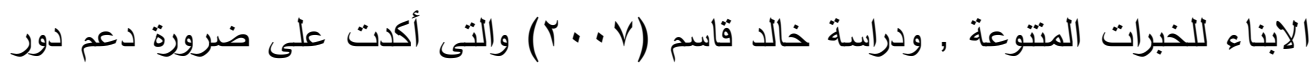

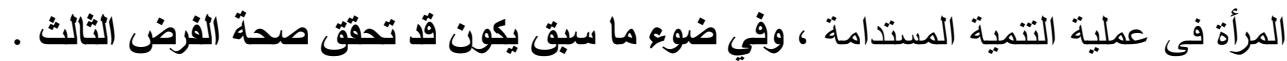

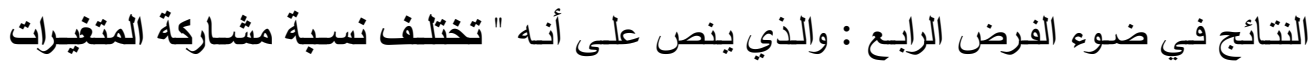

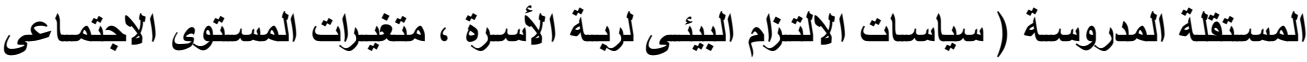

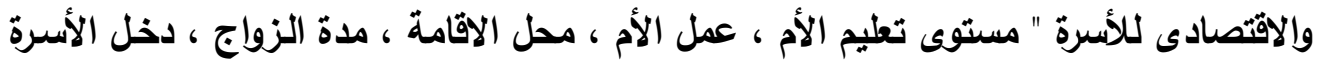

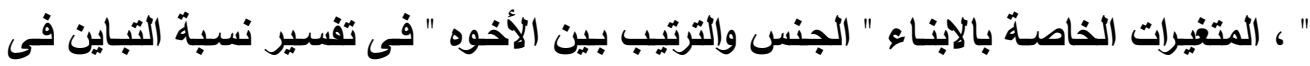
المتغير التابع (الخبرات البيئيسة للأبناء في ضـوء التنميـة المستدامه) تبعـاً لأونان معاملات

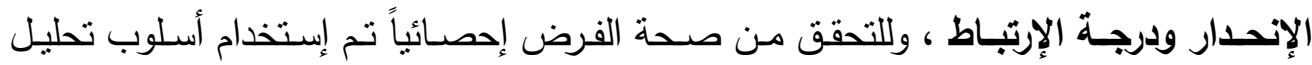

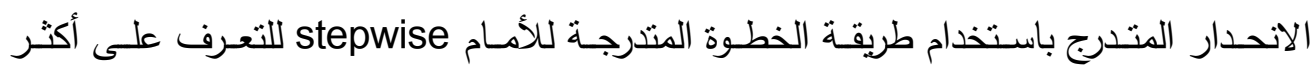
العوامل مساهمة في نسبة التناين في المتغير التابع وجدول (·r) يوضح ذلك . 
جدول ( • r) معاملات الإنحار بإستخدام طريقة الخطوة المتدرجة إلى الأمام للمتغيرات المستقلة

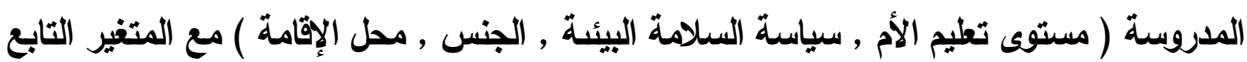
(الخبرات البيئية للأبناء فى ضوء التنمية المستدامهة)

\begin{tabular}{|c|c|c|c|c|c|c|c|c|}
\hline 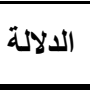 & قَمة & الانحارل & الدلالة & قيمة (ف) & المشاركة & الارتباط & المتغيرات المستقلة & $\stackrel{p}{r}$ \\
\hline 0.01 & 9.020 & 0.436 & 0.01 & 81.357 & 0.744 & 0.863 & مستوى تعليم الأم & \\
\hline 0.01 & 7.535 & 0.338 & 0.01 & 56.781 & 0.670 & 0.818 & سياسة السلامة & E \\
\hline 0.01 & 6.564 & 0.262 & 0.01 & 43.090 & 0.606 & 0.779 & الجنس & E. \\
\hline 0.01 & 5.819 & 0.197 & 0.01 & 33.864 & 0.547 & 0.740 & محل الإقامة & \\
\hline
\end{tabular}

يتضح من جدول (·r) أن المستوى التعليمى للأم هو العامل الأكثر تأثثراً فى تقسير التباين فى

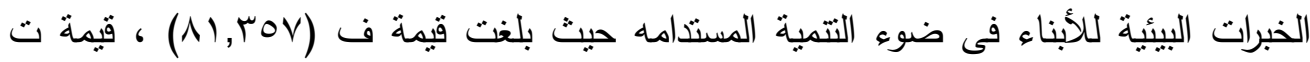

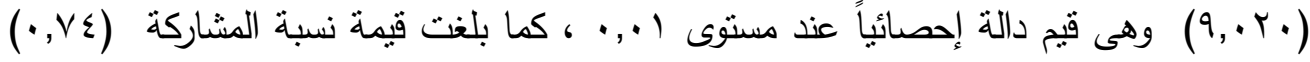

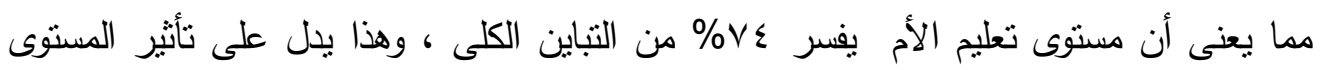

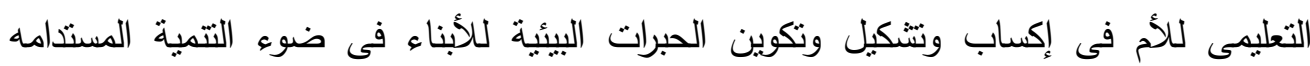
بمجالاتها المختلفة , ويمكن تفسير ذلك بأن الأم هى المرجع الأساسى فى تربية الأبناء والمصدر

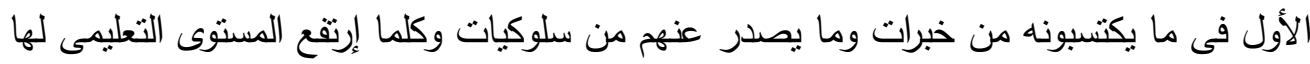
زاد إهتمامها بقضايا البيئة والتلوث وكيفية المساهمة فى الحفاظ على البيئة ونتمية مصادر الطاقة المنتوعة والمشاركة فى عملية التتمية المستخامة , وبالتالى يزداد رصبد ما تقدمه من خبرات إيجابية تتعلق بالبيئة مما يفسر إكتسابهم لهذه الخبرات , وتتفق هذه النتيجة ودراسة كلاً من محمد

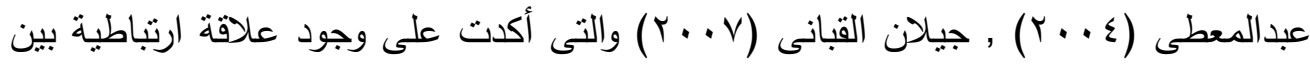

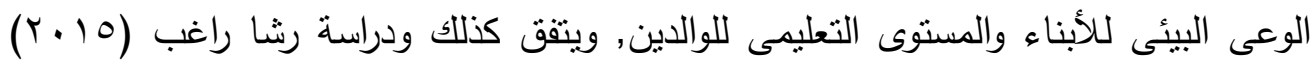
والتى أكدت على وجود فروق فى اكتساب الخبرات البيئية للأبناء تبعاً لمستوى تعليم الأمهات

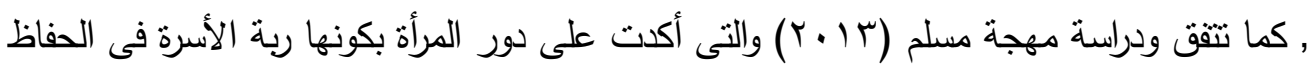

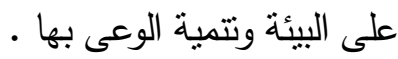

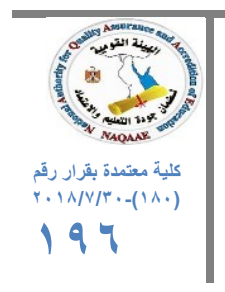

ك ا شارع محمد أمين شهيب - مصطفى كامل ـ الاسكندريه ـ مصر تليفون : 203/5454313

Alexandria - Egypt, Tel. : 203/5454313 - 203/5442776 Fax :203/5442776

E-mail : journal.edusp@alexu.edu.eg Web site: RSSA.edusp@lexu.edu.eg 


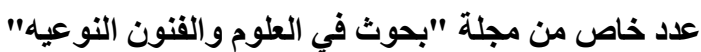

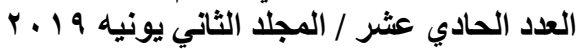

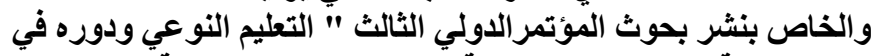

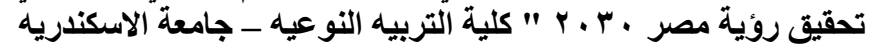

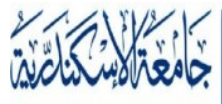

ALEXANDRIA

U N I V ER S I T Y

AlexU Press

viple

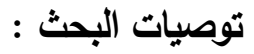

1- إدراج مفاهيم وأهداف التتمية المستدامه ضمن المناهج التعليمية للإقتصاد المنزلى لئى بمختلف المؤسسات التعليمية ، وكذلك ضمن مقرارات البكالوريوس والدراسات العليا كمقرر مشكلات التتمية وإدارة جودة البيئة . r- جعل مقرر التربية البيئية مقرراً إجبارياً وذللك لأهميته في إكساب الأبناء المعارف والمفاهيم البيئية الصحية وما يتعلق بها من قيم وأخلاقيات وسلوكيات بيئية.

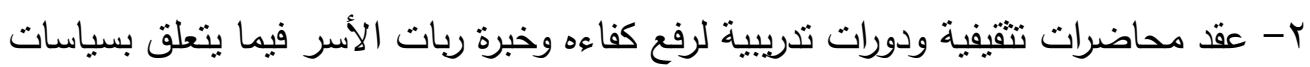

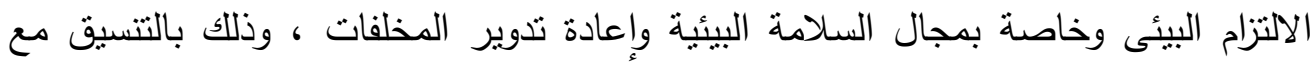
أعضاء هيئة التدريس بقسم إدارة مؤسسات الأسرة والطفولة ووحدة التدريب بكلية الاقتصاد

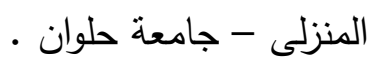
r- إعداد مجموعة من القوافل الطلابية بالتعاون بين قسمى إدارة مؤسسات الأسرة والطفولة والاقتصاد المنزلى التربوى بكلية الاقتصاد المنزلى - جامعة حلوان تهدف لنشر الوعى بأهمية

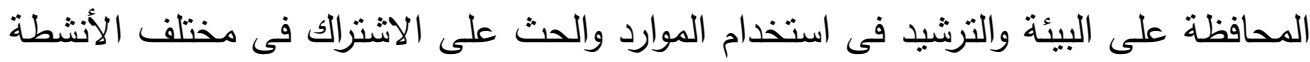
البيئية بين طلاب المدارس وخاصة فى الريف بما يحقق منطلبات التتمية المستدامه .

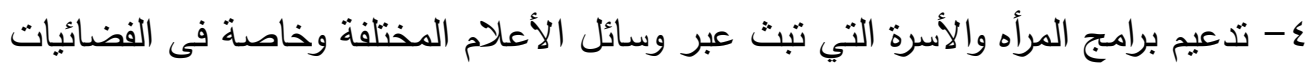
بفقرات تساعد المرأه على الالتزام بالسياسات البيئة داخل مسكنها كالاعتمام على الوصفات الطبيعية وتقليل استخدام المنتجات الصناعية فى نتظيف المسكن ، والطرق المختلفة لإعادة

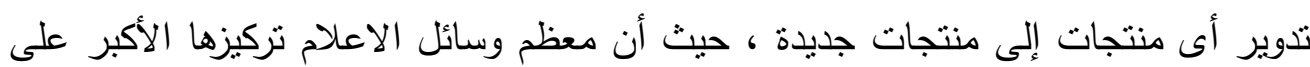
ترشيد استهلاك المياه والكهرباء.

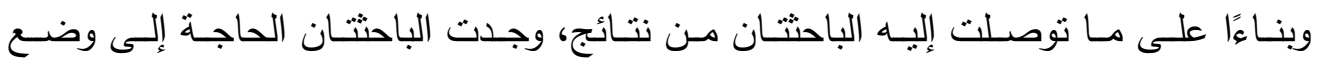

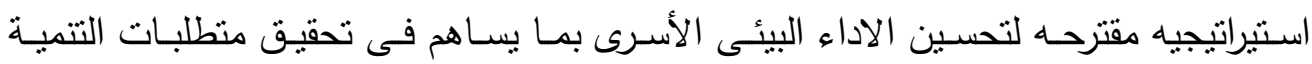

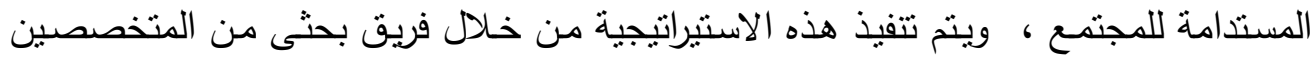


بقسم إدارة مؤسسات الأسرة والطفولة بعقد بروتوكلات تعاون مع القسم والهيئات المعنية بشئون البيئة والأسرة والطفل ( كجهاز شئون البيئة ، المجلس القومى للمرأة ، المجلس القومى للطفولة

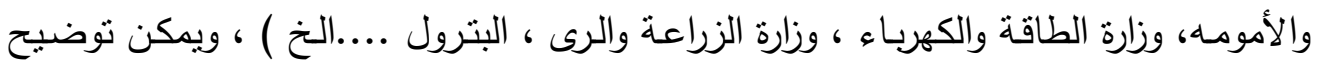
الاستيراتيجية فى الشكل التالي :

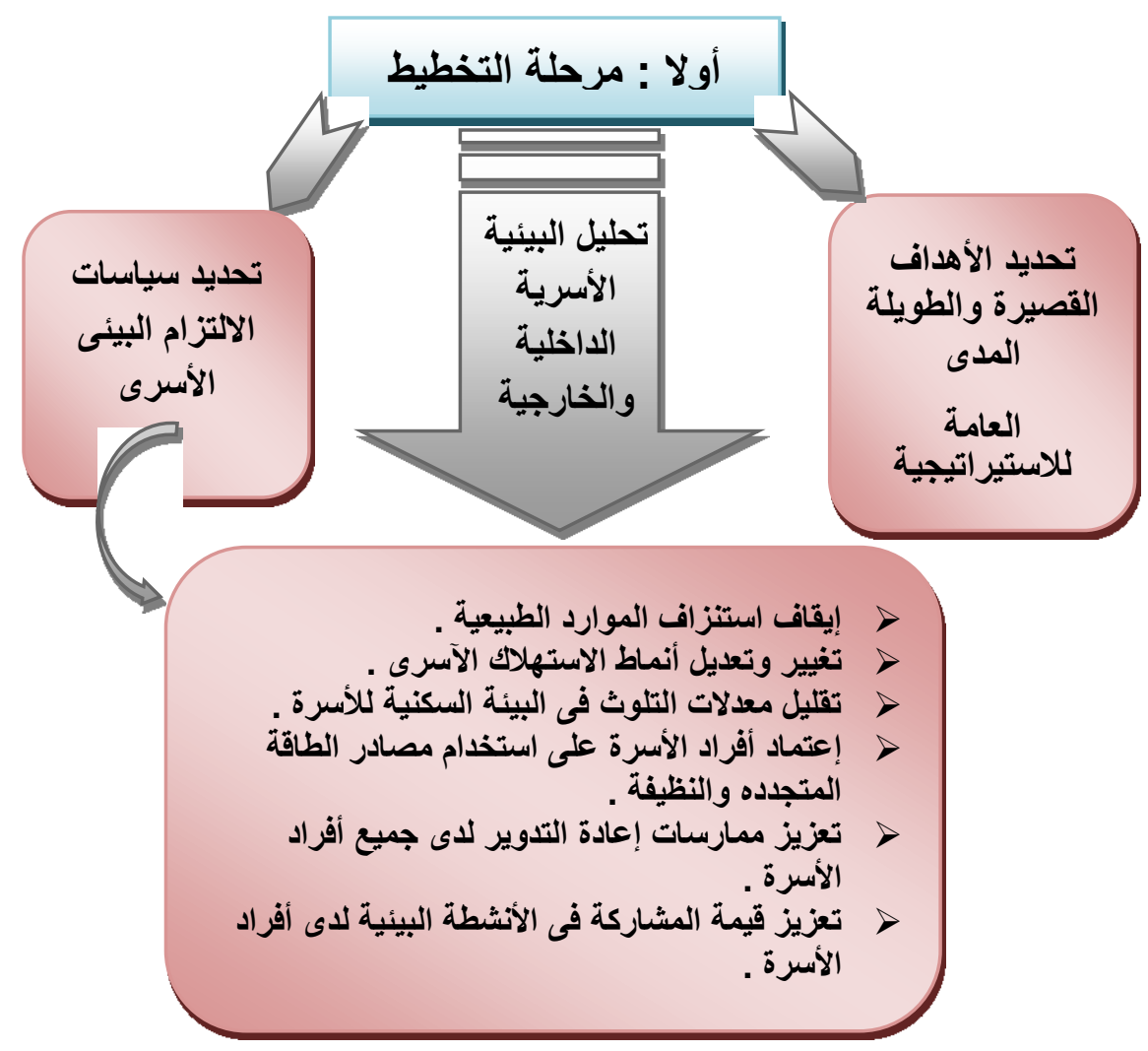

؛ أشارع محمد أمين شهيب ـ مصطفى كامل ـ الاسكندريه ـ مصر تليفون : 203/5454313

Alexandria - Egypt, Tel. : 203/5454313 - 203/5442776 Fax :203/5442776 
عدد خاص من مجلة "بحوث في العلوم والفنون النوعيه"

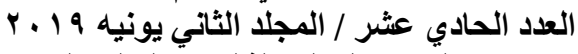

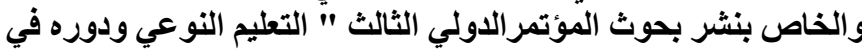

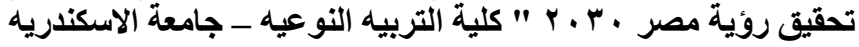

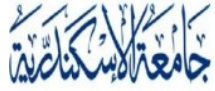

ALEXANDRIA

U N I V E R S I T Y

Alexu Press

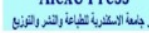

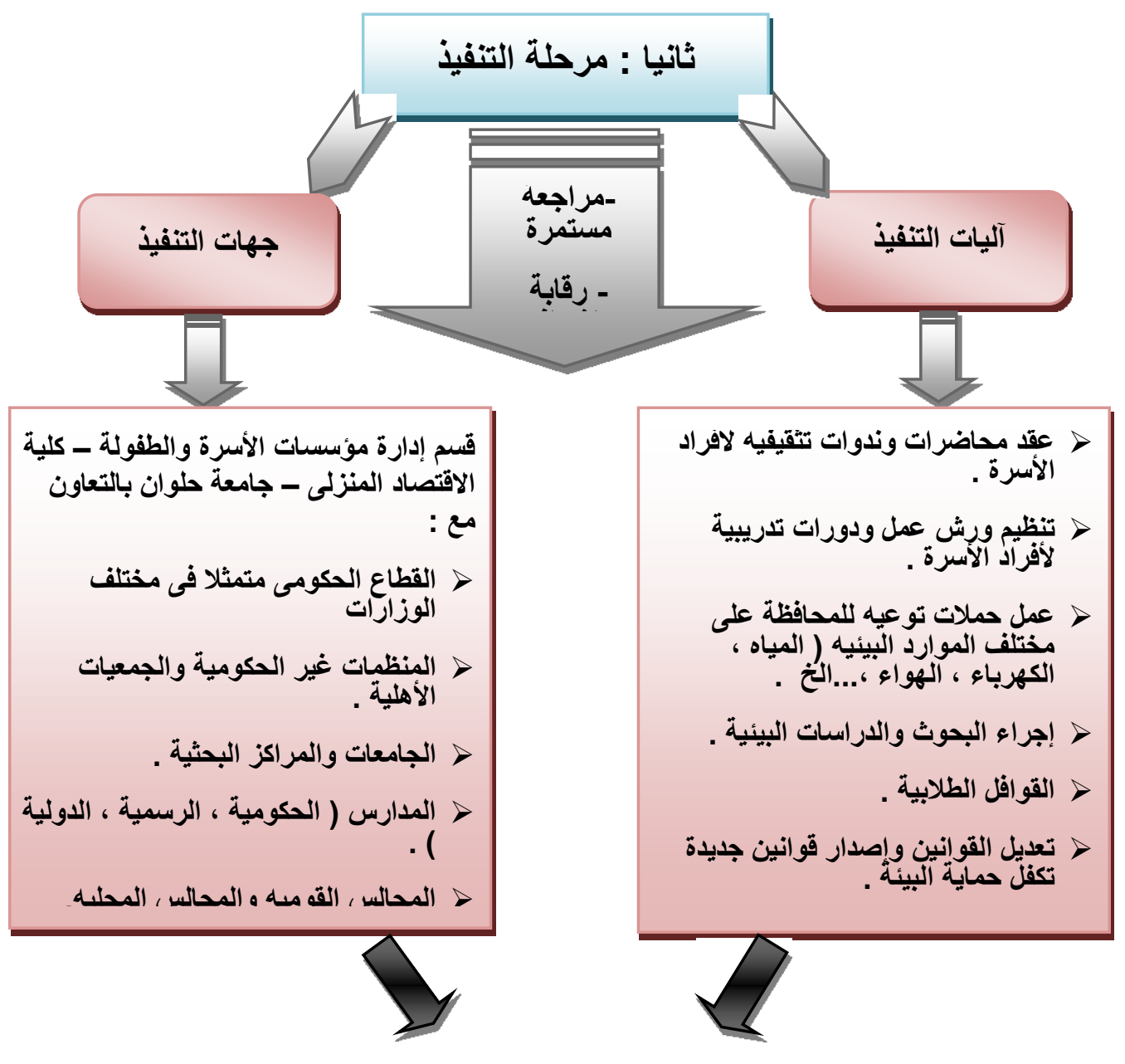

؛ 1 شارع محمد أمين شهيب - مصطفى كامل ـ الاسكندريه ـ مصر تليفون : 203/5454313

Alexandria - Egypt, Tel. : 203/5454313 - 203/5442776 Fax :203/5442776

E-mail : journal.edusp@alexu.edu.eg Web site: RSSA.edusp@lexu.edu.eg 
عدد خاص من مجلة "بحوث في العلوم والقنون النوعيه" المجيه

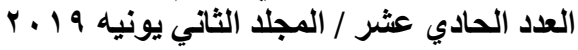

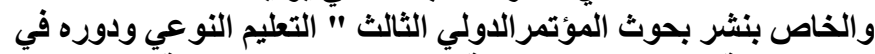

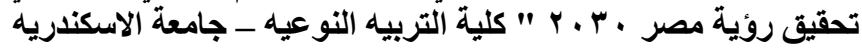

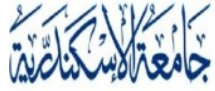

ALEXANDRIA

U N I V E R S I T Y

Alexu Press

(بر)

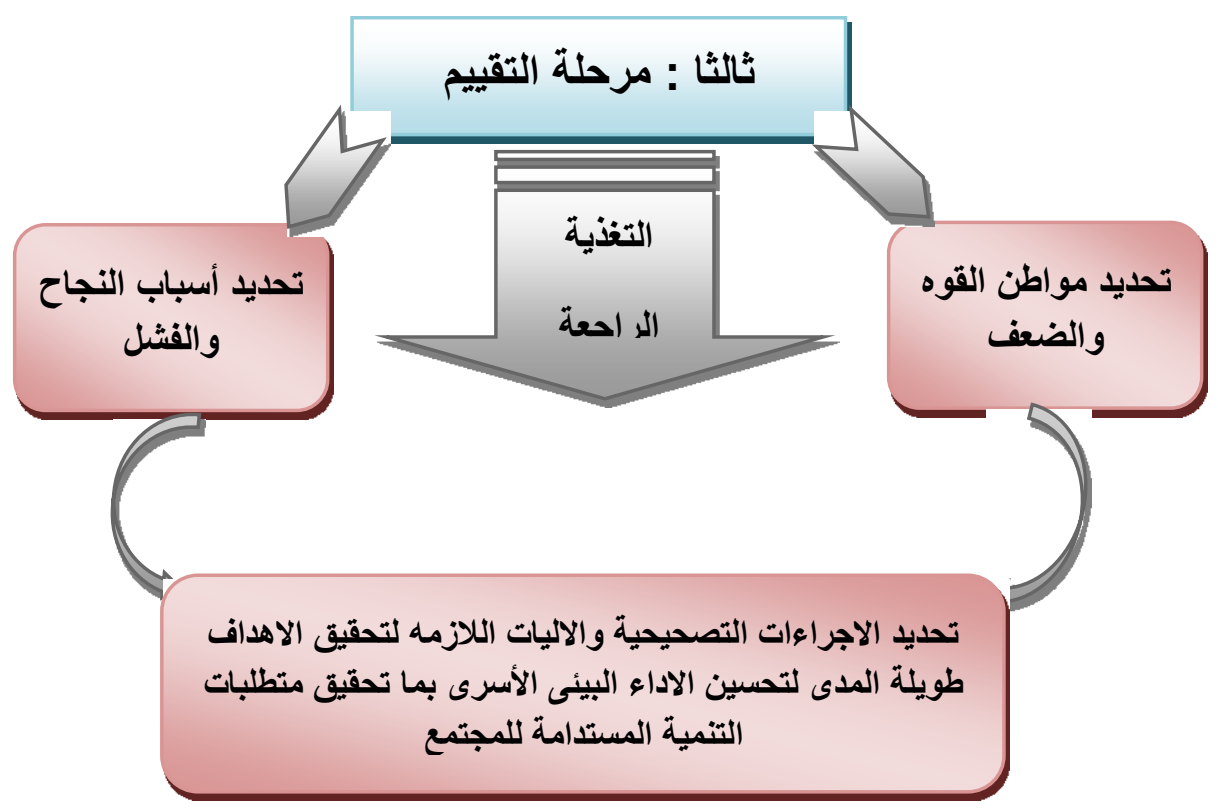

شكل (1) عناصر الاستيراتيجية المقترحه

وفى ضوء نتائج البحث تقترح الباحثثان تطبيق برنـامج إرشـادى بهـف تعزيز إكتساب

المرأه لسياسات الالتزام البيئى .

البرنامج الإرشادى المقترح

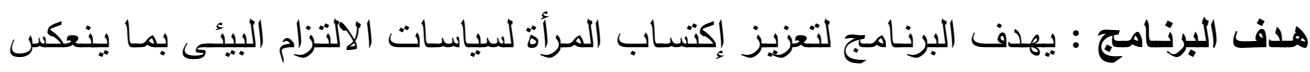

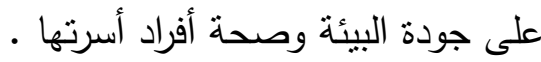

محتوى البرنامج : يتضمن البرنامج أربعة محاور رئيسية وهى :

1- سياسة التخفيض والترشيد فى استخدام الموارد . 


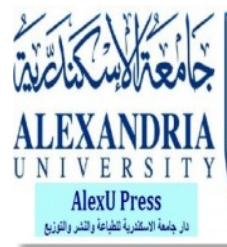

r- سياسة السلامة البيئية .

• س- سياسة إعادة التدوير

ع - سياسة الاصلاح والصيانه المنزلية.

ويستغرق تطبيق هذا البرنامج (9) جلسات وزمن كل جلسة (Y) ساعة ويتم توزيع الجلسات كما هو موضـح

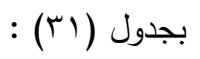

جدول (1/) خطة تطبيق البرنامج الإرشادى المقترح

\begin{tabular}{|c|c|c|c|c|}
\hline إجراءات التقويم & لاستر التيجيات و التوسيائل & لألهداف التعليمية : في نهاية الجلسأ & (محتوى الجلسة العناصرة & وعنوانسة الجلها \\
\hline 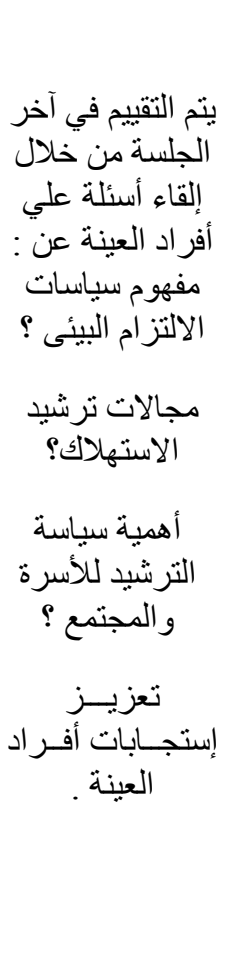 & 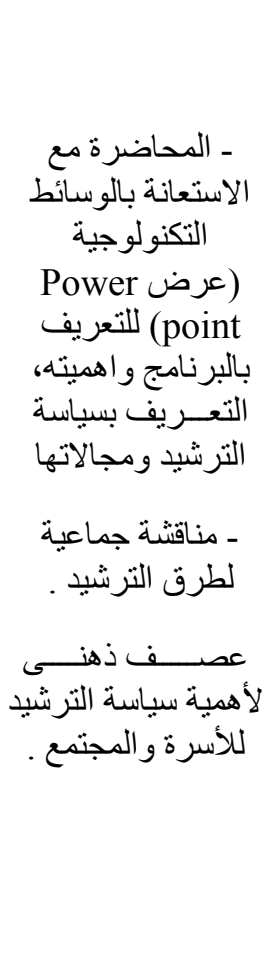 & 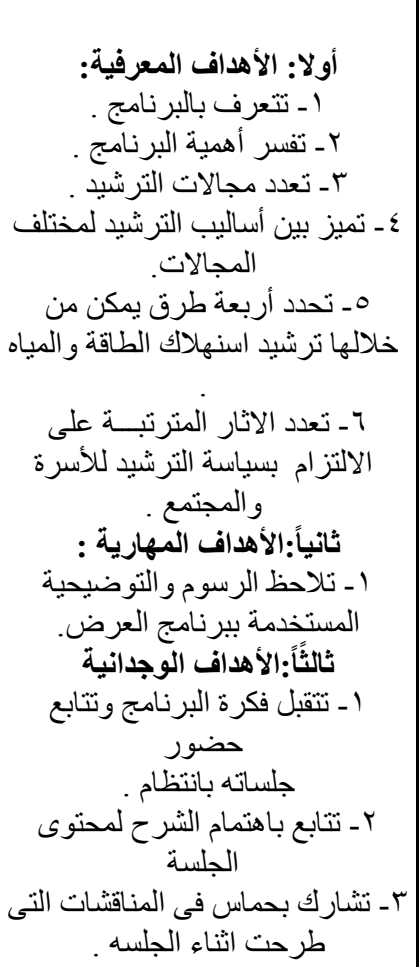 & 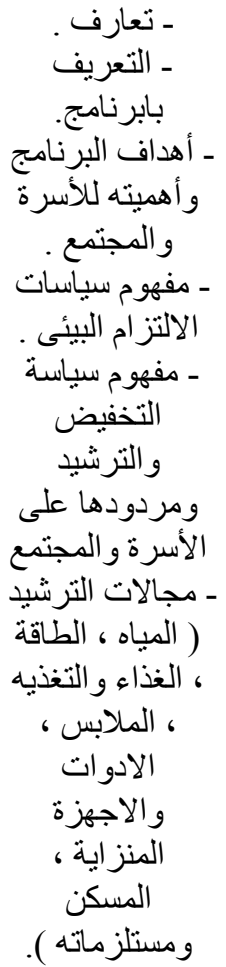 & والتعارف \\
\hline
\end{tabular}

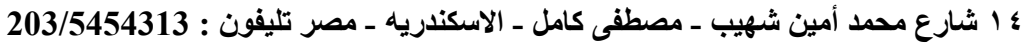

Alexandria - Egypt, Tel. : 203/5454313 - 203/5442776 Fax :203/5442776

E-mail : journal.edusp@alexu.edu.eg Web site: RSSA.edusp@lexu.edu.eg

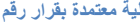

$r \cdot 1 \Lambda / v / r \cdot-(1 \Lambda \cdot)$

$Y .1$

E-mail : journaledusp aalexu,edu.eg Web site: RSSA.edusp@exu.edu.eg 
عدد خاص من مجلة "بحوث في العلوم والقنون النوعيه" التونيه

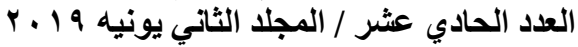

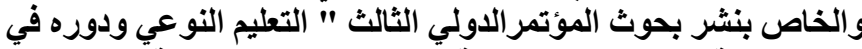

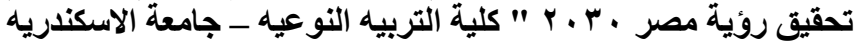

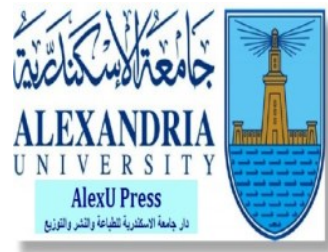

\begin{tabular}{|c|c|c|c|c|}
\hline إجراعات التقويم & والوسائل التُبليمية & 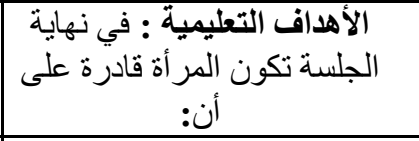 & 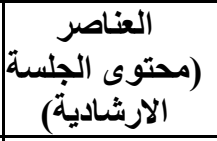 & وعنوانها \\
\hline 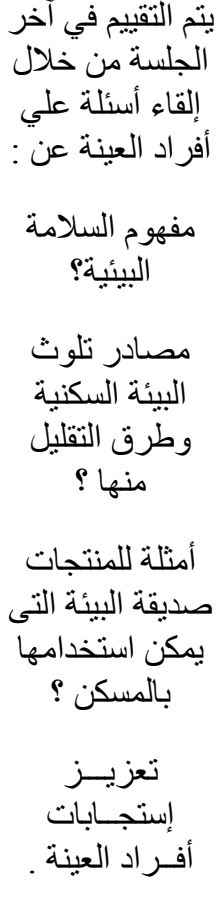 & 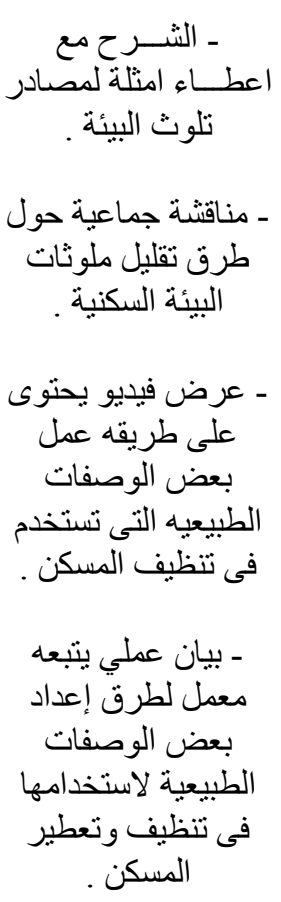 & 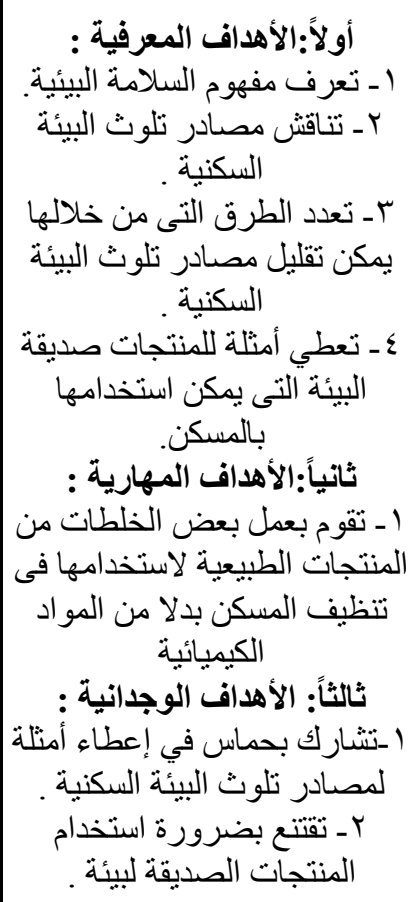 & 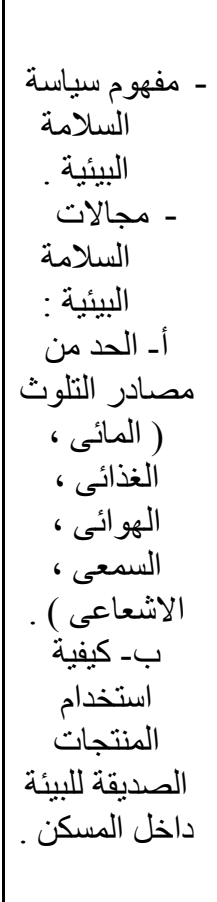 & السيامة \\
\hline 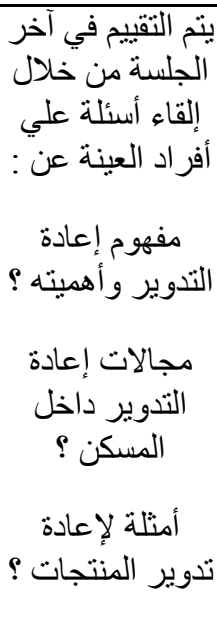 & 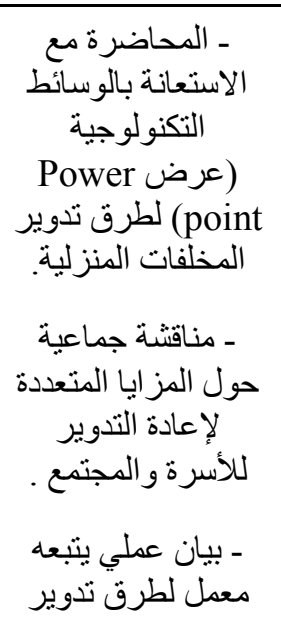 & 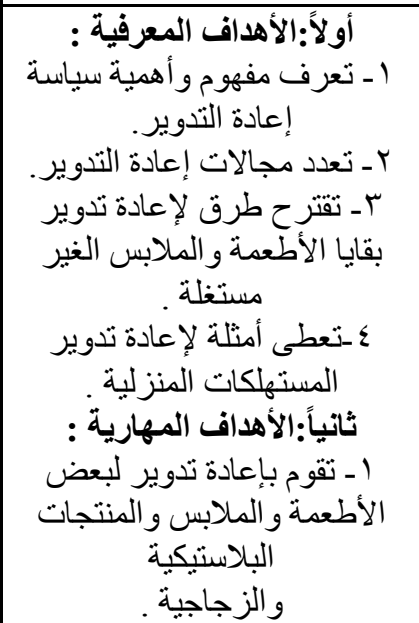 & 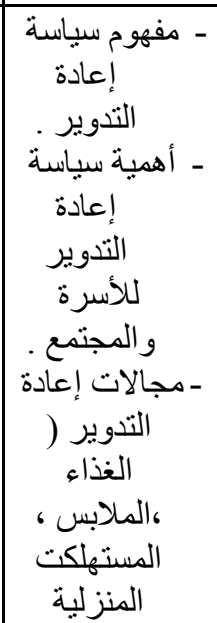 & والسادسة \\
\hline
\end{tabular}

ـ ا شارع محمد أمين شهيب - مصطفى كامل ـ الاسكندريه ـ مصر تليفون : 203/5454313 : 203/547276

Alexandria - Egypt, Tel. : 203/5454313 - 203/5442776 Fax :203/5442776

كلية معتمدة بقر ار رقم

E-mail : journal.edusp@alexu.edu.eg Web site: RSSA.edusp@lexu.edu.eg

$Y \cdot Y$ 
عدد خاص من مجلة "بحوث في العلوم والقنون النوعيه" التونيه

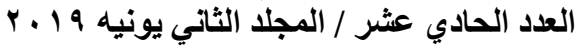

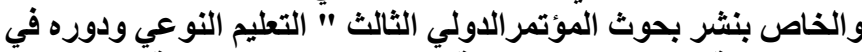

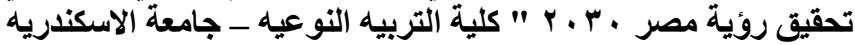

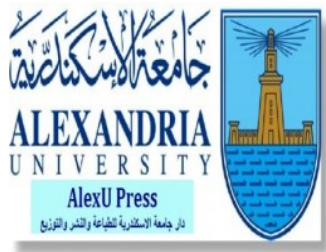

\begin{tabular}{|c|c|c|c|c|}
\hline 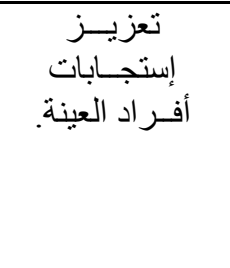 & الورقية و الزعام ، الملابس ، الزجاتية . & 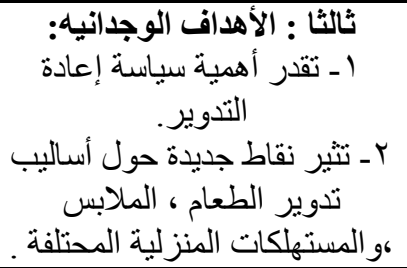 & 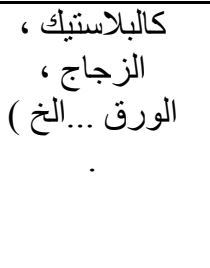 & \\
\hline 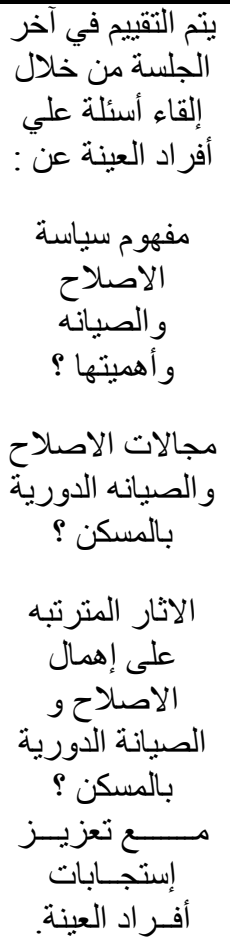 & 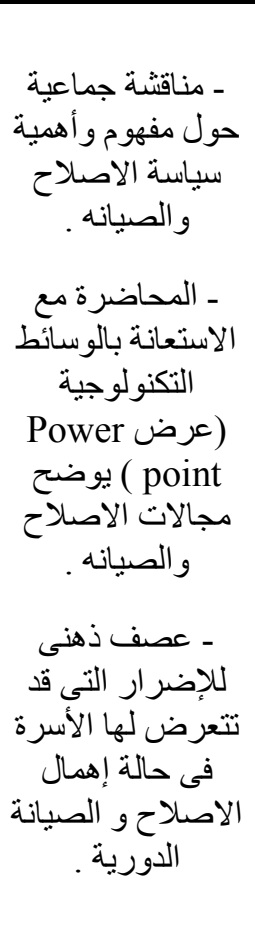 & 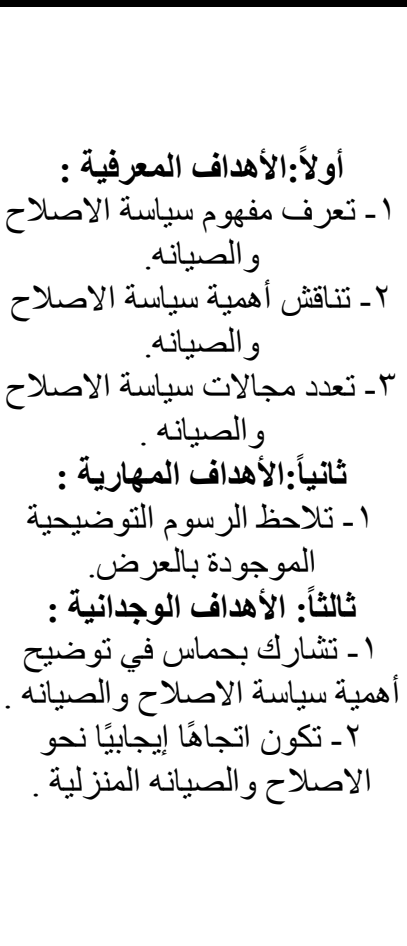 & 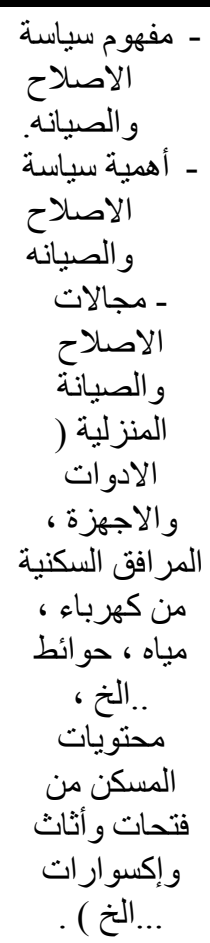 & والثابنة \\
\hline \multicolumn{4}{|c|}{ شكر وختام البرنامج ـ تقييم البرنامج الإرشادى من خلال توزيع الادوات البحثية لقياس مدى البادئ } & وختشام \\
\hline
\end{tabular}

؛ أشارع محمد أمين شهيب ـ مصطفى كامل ـ الاسكندريه ـ مصر تليفون : 203/5454313

Alexandria - Egypt, Tel. : 203/5454313 - 203/5442776 Fax :203/5442776

E-mail : journal.edusp@alexu.edu.eg Web site: RSSA.edusp@lexu.edu.eg

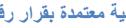

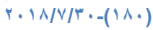

$r \cdot r$ 


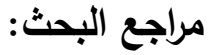 \\ اولاً: المراجع العربية : العاجية}

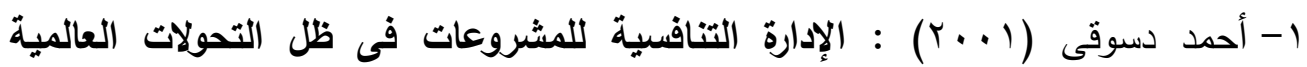

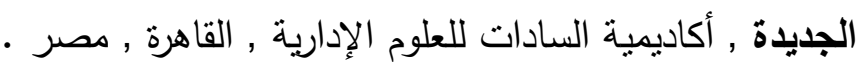

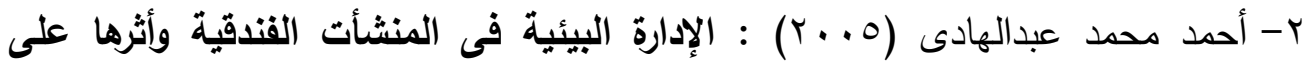
الطلب السياحى , حالة تطبيقية على منطقة البحر الأحمر , رسالة ماجستير غير منشورة , معهد الدراسات والبحوث البيئية , جامعة عين شمس , القاهرة , مصر •

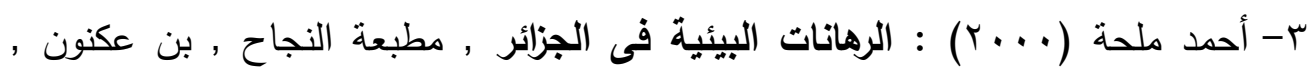

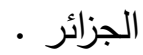

ع - أسماء صفوت جمال الكردى (9 . . ب) : إتجاهات المرأة نحو صيانة وإصلاح المرافق والأجهزة المنزلية وعلاقتها بالتخطيط الاستراتيجى للاخل المالى , رسالة ماجستير غير

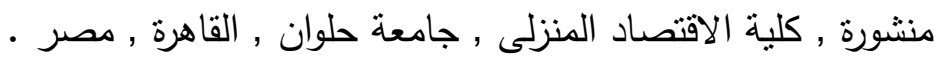

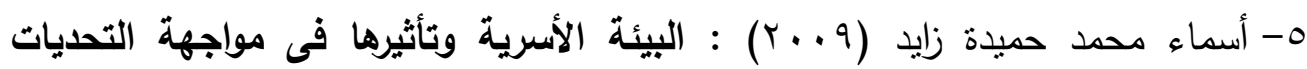
المعاصرة لاى طلاب الجامعة , رسالة دكتوراه غير منشورة , قسم الاقتصاد المنزلى ,

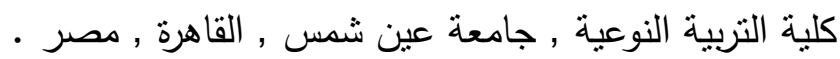

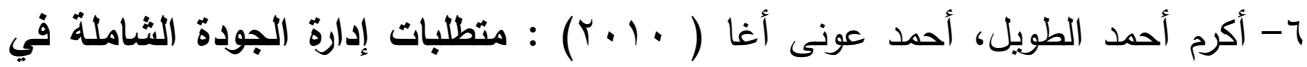
التعليم العالي وأثرها في تحقيق التنمية المستدامة- المؤتمر العلمي الرابع- جامعة

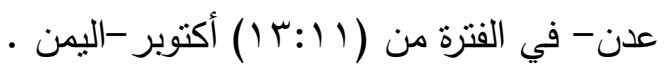

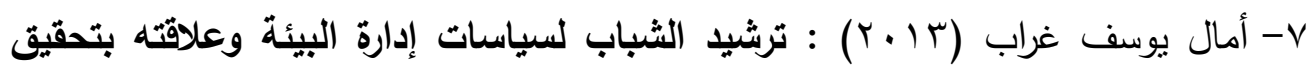
الاقتصاد البيئى الأخضر فى ضوء منظومة التنمية المستدامة , المؤتمر الدولى الأول

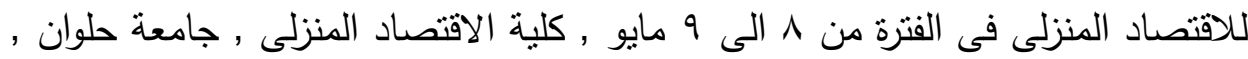
القاهرة , مصر - مصر 


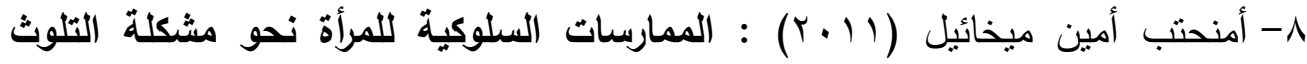
البيئى فى مصر , رسالة دكتوراه غير منشوره , معهد الدراسات والبحوث البيئية , جامعة

$$
\text { عين شمس , القاهرة , مصر • }
$$

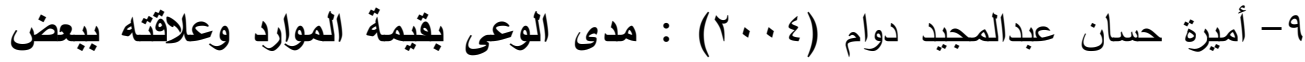
مشكلات المراهقين , رسالة ماجستير غير منشورة , كلية الاقتصاد المنزلى , جامعة

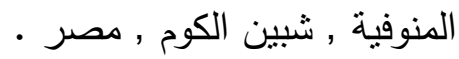

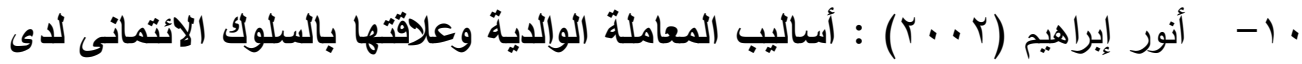
الأطفال , رسالة ماجستير غير منشورة , معهد دراسات الطفولة , جامعة عين شمس ,

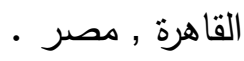

1) - إيمان عبدالسلام عبدالقادر (r.V) : إتجاه السيدات نحو ترشيد الاستهلاك الملبسى فى محافظة جدة , المؤتمر الثانى , معايير ضمان الجودة والاعتماد فى التعليم النوعى بمصر والوطن العربى ,فى الفترة من Iا الى ז ا إبريل , كلية التربية النوعية , جامعة المنصورة , المنصورة , مصر •

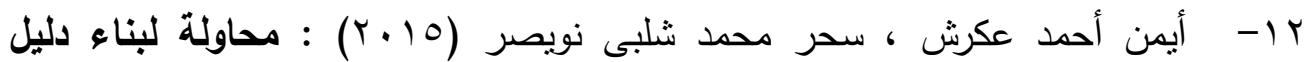
لقياس وعى الريفين بممارسات التنمية المستدامة فى ريف محافظة الثرقية , مجلة العلوم الزراعية والاقتصادية والاجتماعية , المجلد (؟) العدد (ץ ا) , جامعة المنصورة ,

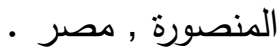

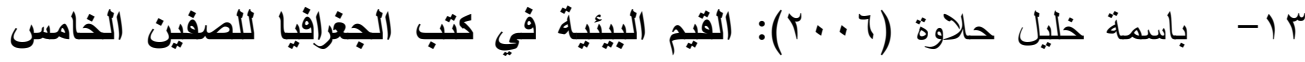
والسادس من مرحلة التعليم الأساسي في سورية (دراسة تحليلية تقويمية للقيم البيئية المتضمنة في الكتب) , بحث منشور في مجلة جامعة دمشق , المجلد (Yr) العدد (Y) , جامعة دمشق , دمشق , سوريا . 


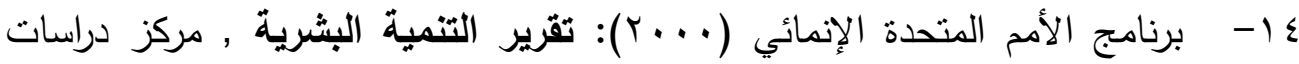
الوحدة العربية , القاهرة , مصر •

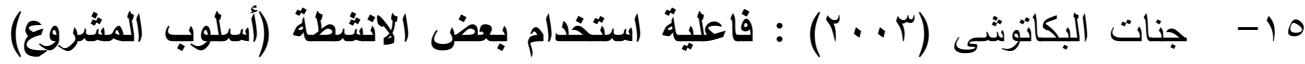
كمخل للتربية البيئية فى رياض الأطفال , رسالة دكتوراه غير منشورة , معهد الدراسات التربوية , جامعة عين شمس , القاهرة , مصر •

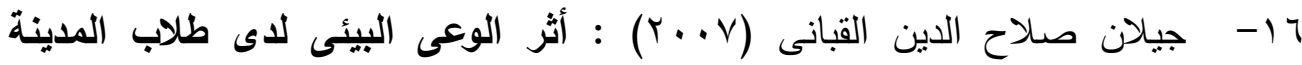

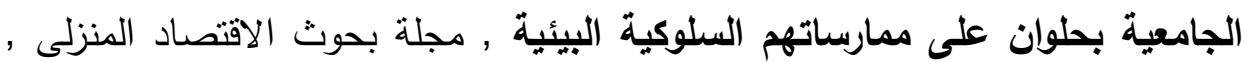

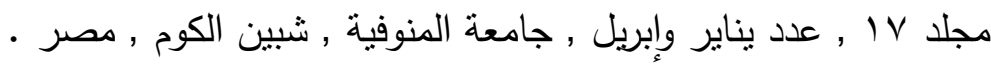
IV

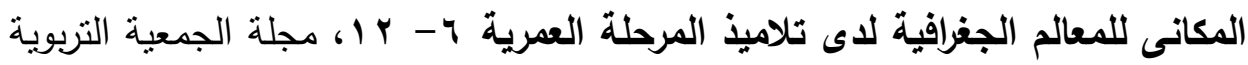

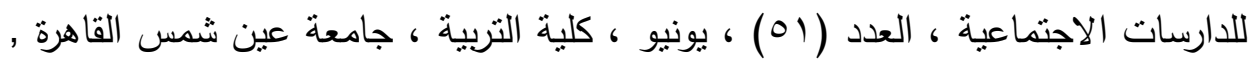

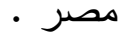

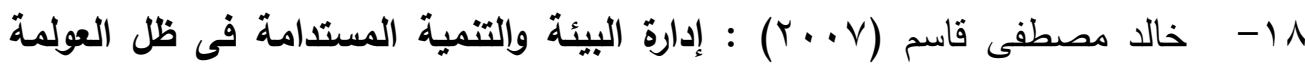
المعاصرة , الدار الجامعية , الاسكندرية , مصر.

19- ذوقان عبيدات، عبد الرحمن عدس، كايد عبد الحق (Y (Y): البحث العلمي مفهومة وأدواته وأساليبه , طانيات |1 , دار أسامة للنشر والتوزيع , السعودية .

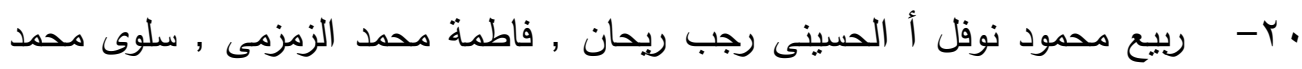

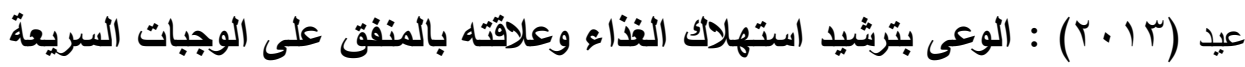

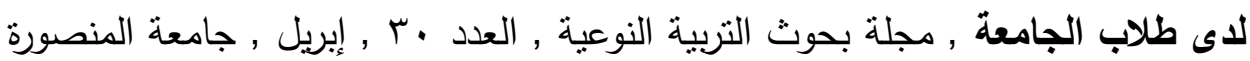
•

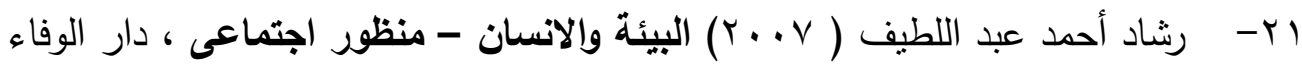

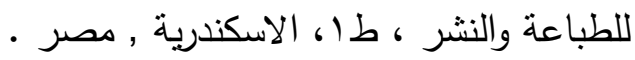


r

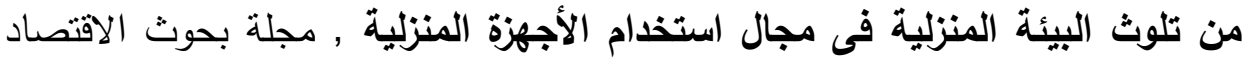
المنزلى و مجلد V I , العدد (Y/T) يناير /إبريل , جامعة المنوفية , شبين الكوم , مصر.

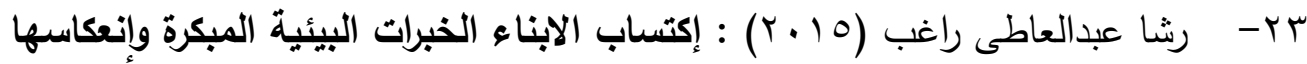
على كفاعتهم الاجتماعية وقدرتهم على التخطيط للمستقبل , بحث منشور فى مجلة بحوث فى العلوم والفنون النوعية , المجلد الأول , العدد الثالث , يونيه 10 ـب , كلية

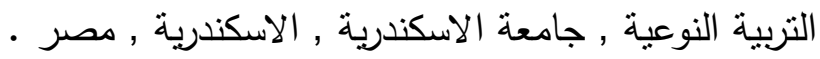

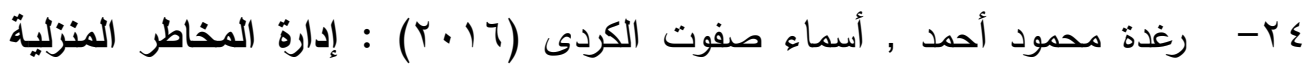
وإنعكاسها على جودة الحياة كما تدركها المرأة , بحث منشور فى المؤتمر الدولى الرابع

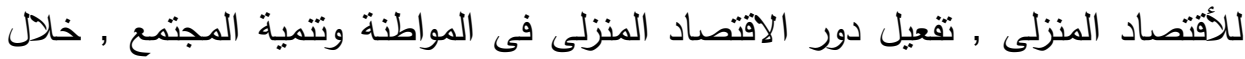

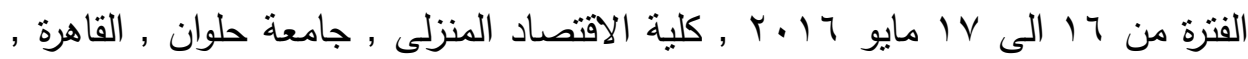
مصر

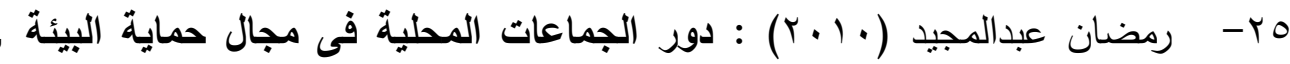
دراسة حالة الجزائر , مذكرة لنيل شهادة الماجستير , فرع القانون العام , تخصص إدارة الجماعات المحلية والإقليمية , كلية الحقوق والعلوم السياسية , جامعة قاصدى مرباح , • ورقلة , الجزائر צr- زينب صلاح يوسف (10 ب) : إستراتيجية ترشيد الاستهلاك الأسرى من أجل التتمية المستدامة وعلاقتها بجودة الحياة , المؤتمر العلمى السنوى العربى العاثر الدولى السابع , التعليم العالى النوعى فى مصر والعالم العربى ودوره فى تتمية المجتمع , فى الفترة من 10 الى 17 إبريل , كلية التربية النوعية , جامعة المنصورة , المنصورة , 


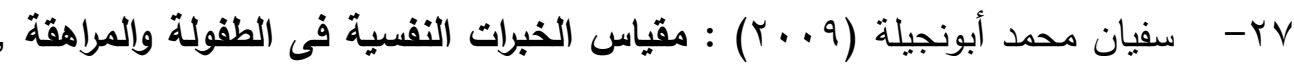
مركز البحوث الإنسانية والتتمية الاجتماعية , غزة , فلسطين •

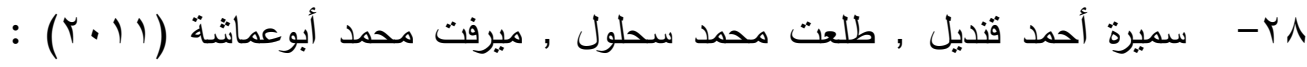

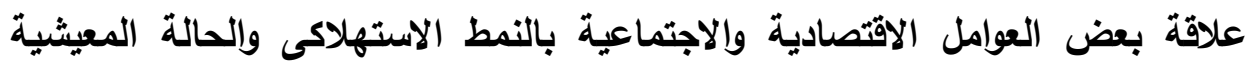

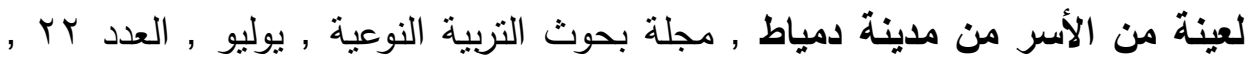
جامعة المنصورة , المنصورة , مصر • من المبرة

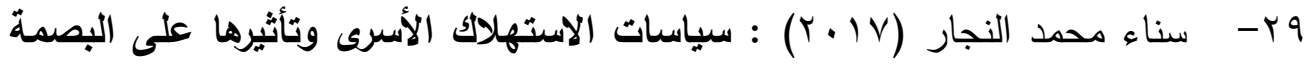
البيئية فى ضوء التمية المستدامة , بحث منشور فى مجلة الاقتصاد الزراعى والعلوم الاجتماعية , مجلد م , العدد (1) , عدد يناير , جامعة المنصورة , المنصورة , مصر.

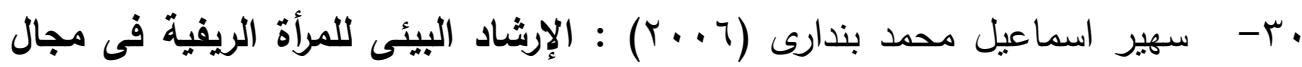

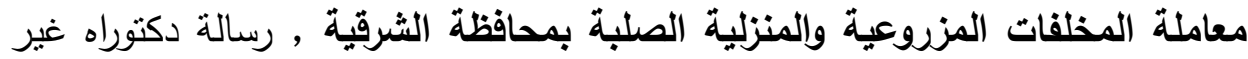
منشورة , كلية الزراعة , جامعة عين شمس , القاهرة , مصر •

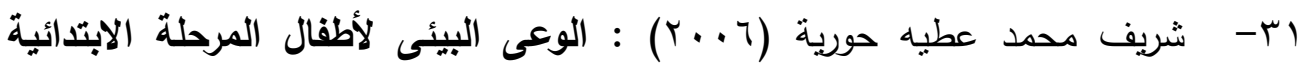
وعلاقته بممارسة بعض العادات الصحية , رسالة ماجستير غبر منشورة , كلبة الاقتصاد المنزلى , قسم إدارة المنزل والمؤسسات , جامعة المنوفية , شبين الكوم , مصر .

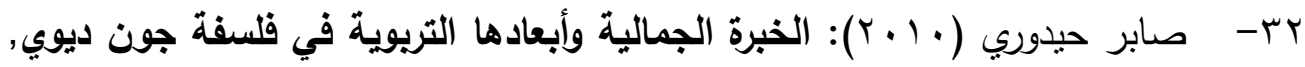
مجلة جامعة دمشق , المجلد بr العدد (r) , دمشق , سوريا .

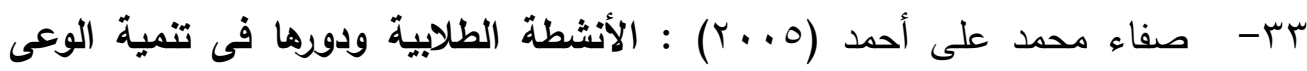
السياسى لاى طلاب الجامعة , رسالة ماجستير غير منشورة , كلية البنات , جامعة عين

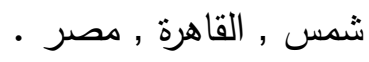


گ قطر نحو مشكلة التلوث البيئى , رسالة ماجستير غير منشورة , معهد الدراسات والبحوث

$$
\text { البيئية , جامعة عين شمس , القاهرة , مصر • }
$$

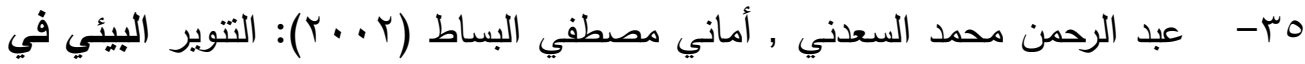
مجلات الأطفال العربية) دراسة تحليلية نقية. بحث منشور في مجلة المؤتمر الدولي

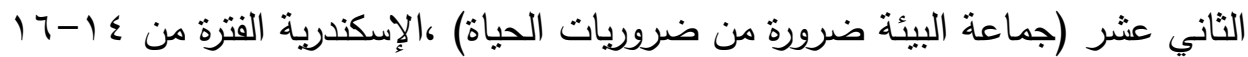

$$
\text { مايو , الاسكندرية , مصر ماجن }
$$

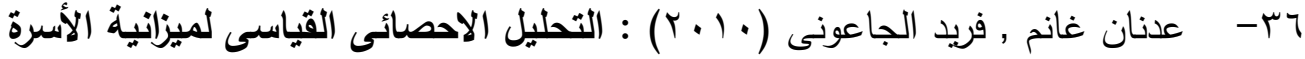
وإتجاهات سلوك المستهلك "النظام اللوغارتمى غير المباشر" , مجلة جامعة دمشق للعلوم الاقتصادية والقانونية , المجلد بr , العدد الأول , • • r , دمشق , سوريا.

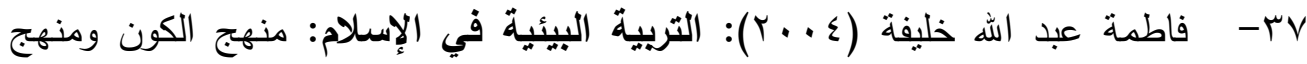

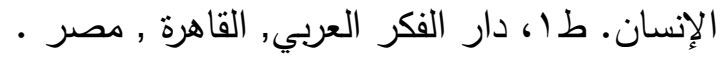

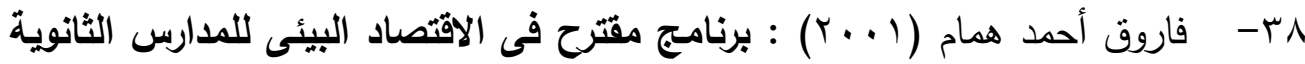

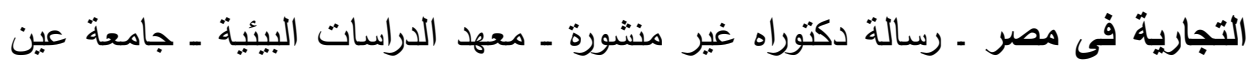

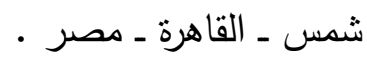

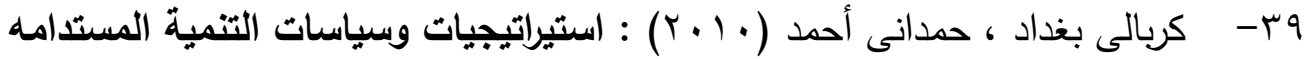

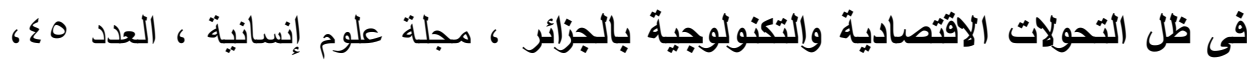

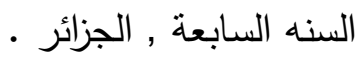

• - - كسيرة أمينة (11) تخصص الاتصال البيئى , قسم علوم الاتصال , كلبة العلوم السياسية والإعلام , جامعة

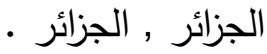


اء - ماجدة أحمد أبو زنط، عثمان محمد غنيم (• (1): التنمية المستدامة من منظور الثقافة العربية الإسلامية -مجلة دراسات العلوم الإدارية -مجلد رقم (بr) -عدد( (1)

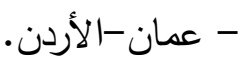

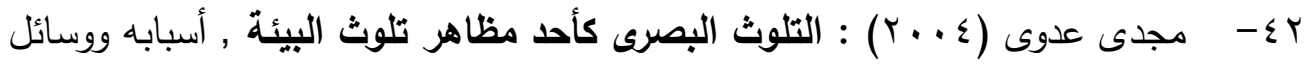
علاجه , مؤتمر الفن والبيئة , كلية التربية الفنية , جامعة حلوان , القاهرة , مصر •

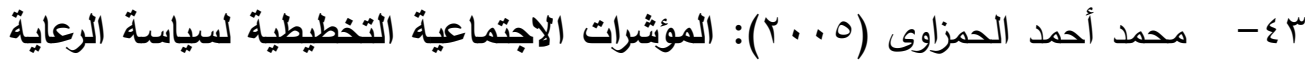
الاجتماعية للمرأة المعيلة , المؤتمر العلمي الثامن عثر "الخدمة الاجتماعية والإصلاح الاجتماعي في المجتمع العربي المعاصر "كلية الخدمة الاجتماعية , جامعة حلوان, مصر

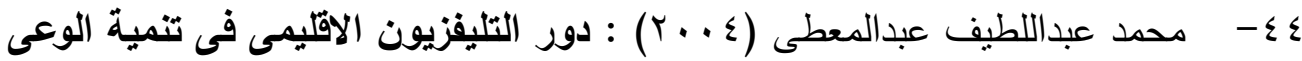
البيئى لدى الأطفال , دراسة تحليلية وميدانية على التليفزيون المصرى والألمانى , رسالة

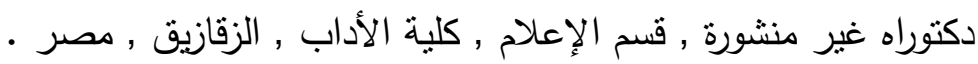

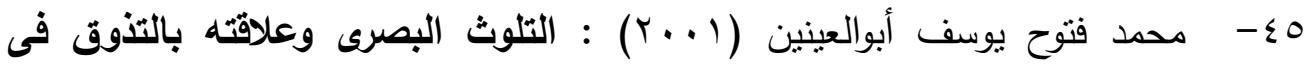
مرحلة الطفولة المتأخرة , رسالة ماجستير غبر منشورة , معهد دراسات البيئة , قشم الدراسات الإنسانية , جامعة عين شمس , القاهرة , مصر .

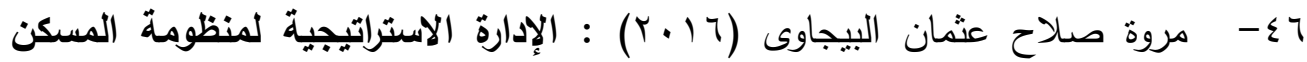
الأكى وإنعكاسها على جودة الحياة الأسرية كمدخل للتنمية المستدامة , رسالة دكتزراه غير منشورة , قسم إدارة مؤسسات الأسرة والطفولة , كلية الاقتصاد المنزلى , جامعة حلوان , القاهرة , مصر •

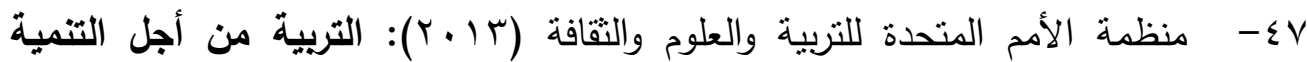
المستدامة - اليونسكو. المنام 
1ـ - منى مصطفى الزاكى (10 ب ب) : الاتجاه نحو متطلبات التصميم الداخلى للمسكن وعلاقته بالسلوك الثرائى لدى الثباب المقبل على الزواج , مجلة بحوث التربية النوعية

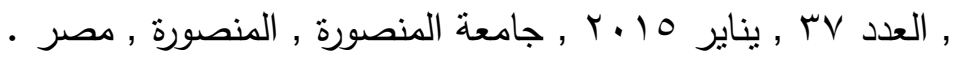

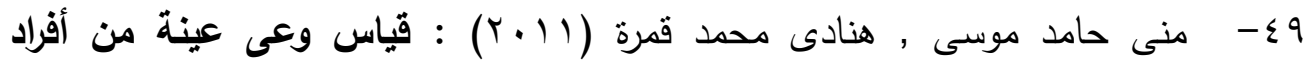
المجتمع بمفهوم المساكن الأكية وعلاقتها بالرضا السكنى , مجلة بحوث التربية النوعية

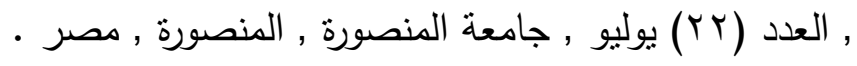

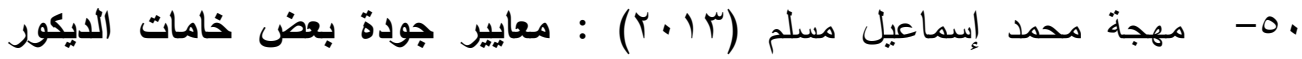
وعلاقتها بتلوث البيئة السكنية , الجمعية المصرية للاقتصاد المنزلى , مجلة الاقتصاد

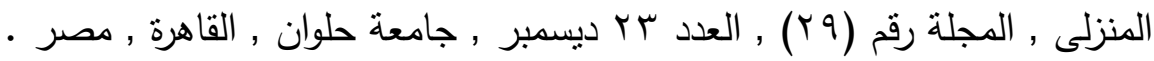

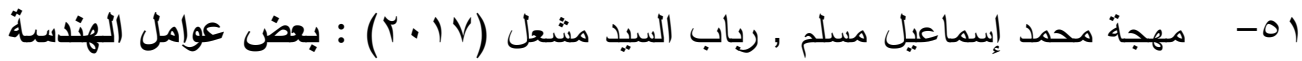
البشرية فى الكفاءة الانتاجية لرية الأسرة , المؤتمر العلمى الدولى الخامس لكلية التربية

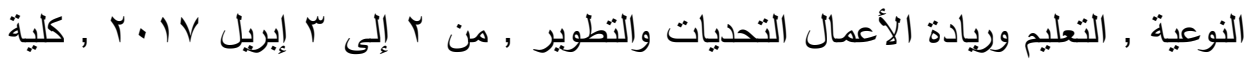

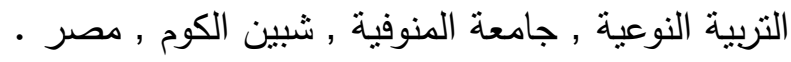

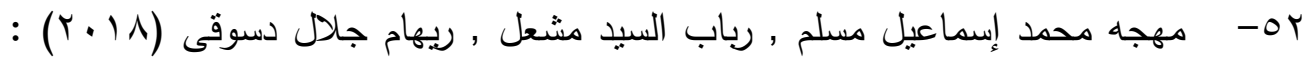
فاعلية برنامج لتنمية وعى المقبلين على الزواج بالمساكن الذكية وعلاقتها بالطاقة

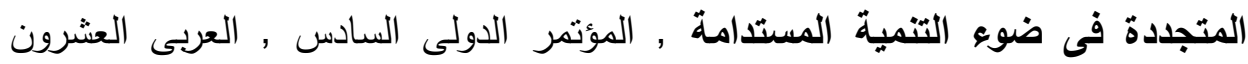

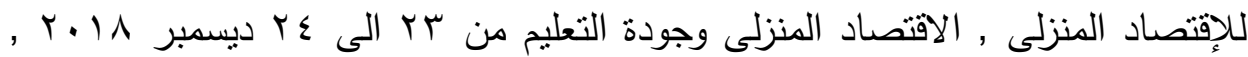

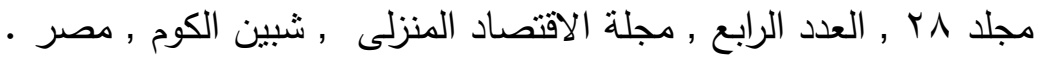

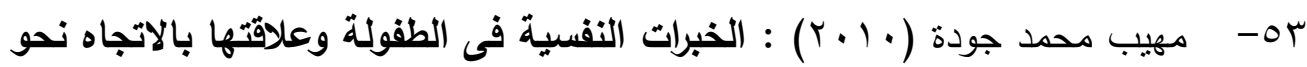
المشاركة السياسية لاى الطلبة الجامعين بقطاع غزة , رسالة ماجستير غير منشورة , كلية التربية , قسم علم النفس , جامعة الأزهر بغزة , فلسطين . 


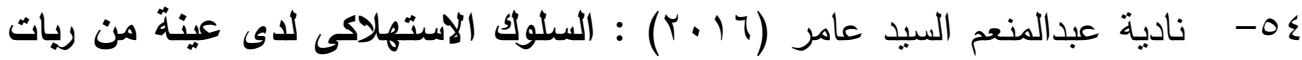
الأسر وعلاقته بالتنمية المستدامة , بحث منشور فى المؤتمر العلمى الدولى الرابع " تفعيل دور الاقتصاد المنزلى فى المواطنة وتتمية المجتمع " , من 17 الى V Vايو , ل

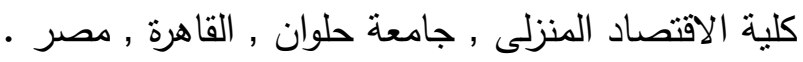

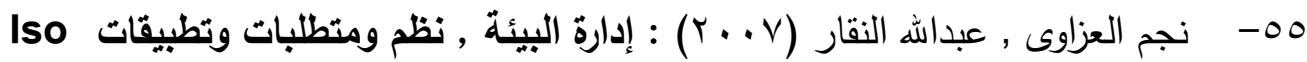
14000 , دار المسيرة للنشر والتوزيع والطباعة , الطبعة الأولى , عمان , الأردن •

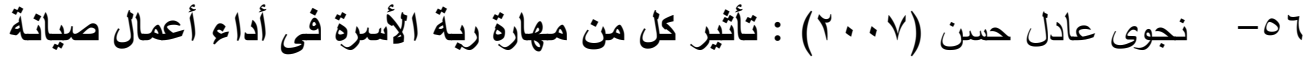
وإصلاح المرافق المنزلية والدافع للإنجاز على حالة المسكن , المؤتمر العربى الحادى هن لهن

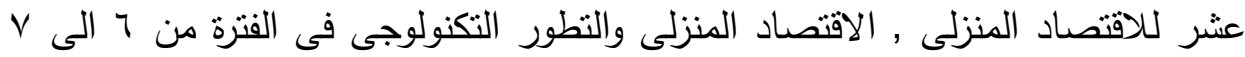
أغسطس , كلية الاقتصاد المنزلى , جامعة المنوفية , شبين الكوم , مصر .

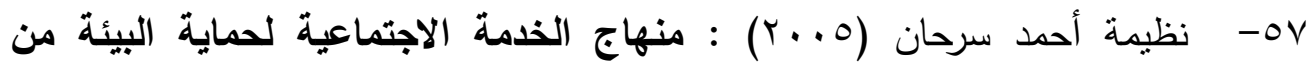

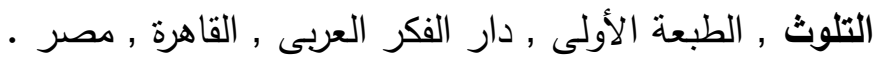

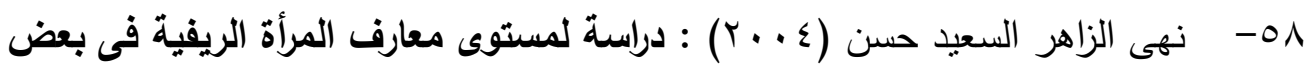
المجالات المتعلقة بالحفاظ على البيئة بمركز كفر الثيخ , رسالة ماجستير غير منشورة

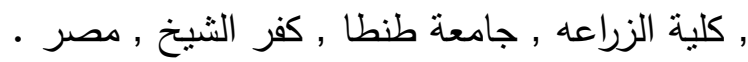

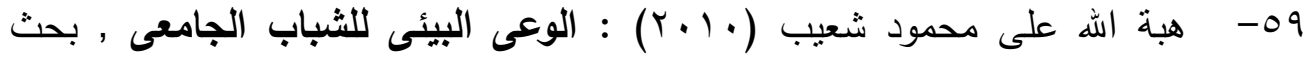
منشور فى المجلة الافريقية للعلوم البيولوجية الصادرة من الجمعية الافريقية للتتمية

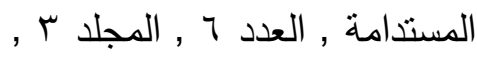

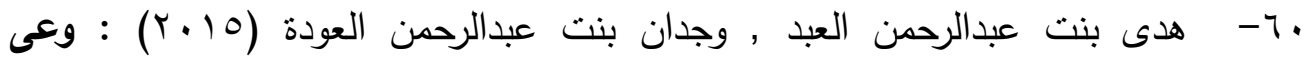

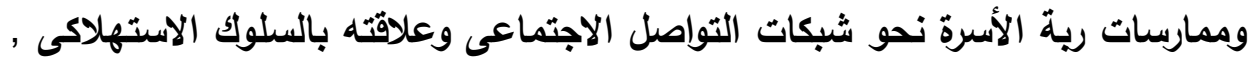
مجلة البحوث الاقتصادية والاجتماعية , مارس , جامعة المنصورة , المنصورة , مصر. 
آ- هنادى محمد عمر قمرة (Y...T) : القيم الأسرية وعلاقتها بأنماط السلوك الاستهلاكى للأسرة السعودية , رسالة ماجستير غير منشورة , كلية التربية للاقتصاد

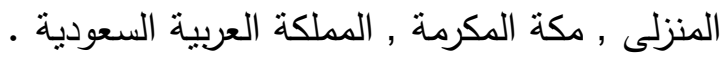

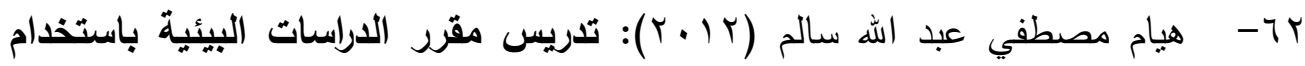

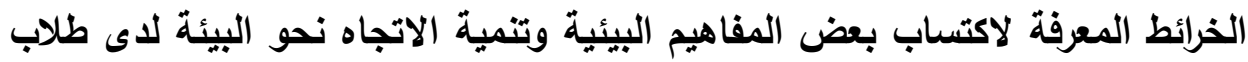
التربية النوعية , مجلة دراسات تربوية واجتماعية , كلية التربية , جامعة حلوان , المجلد

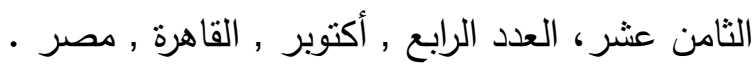

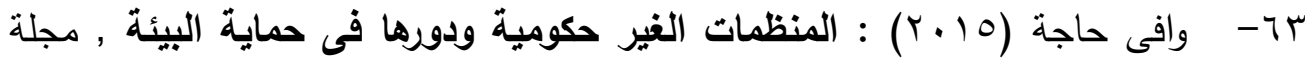
جيل الدراسات السياسية والعلاقات الدولية , جامعة عبدالحميد بن باديس , الجزائر .

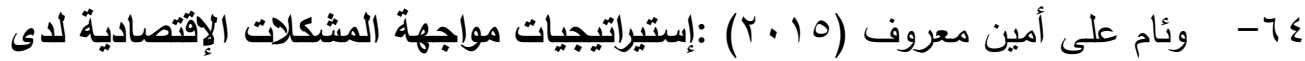
الزوجة وعلاقتها بسماتها الشخصية ، بحث منشور في مجلة كلية الاقتصاد المنزلي ،

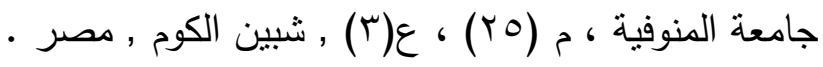

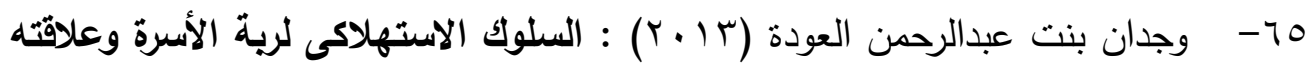
بالتوافق الأسرى , مجلة بحوث التربية النوعية , أكتوبر , عددץr , جامعة المنصورة , • المنصورة , مصر المبرئ

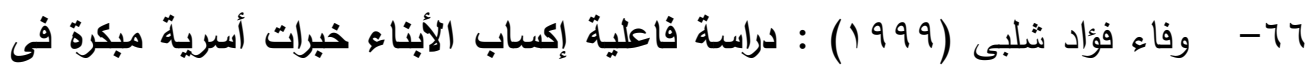

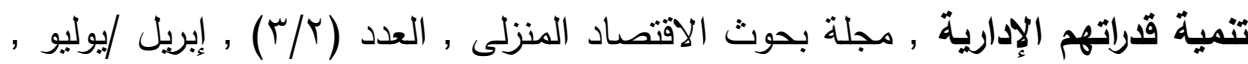

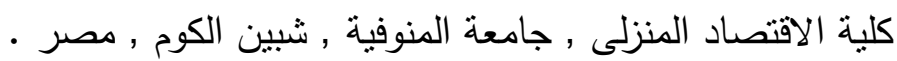

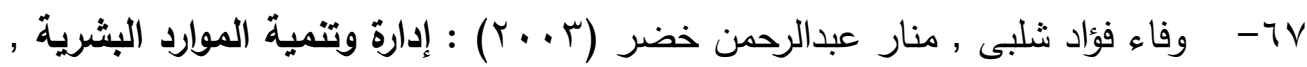

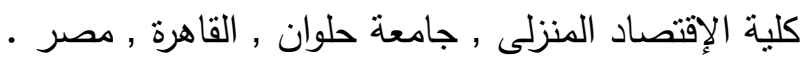




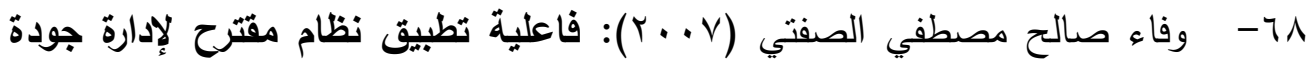
البيئة المنزلية (دراسة تجريبية) , رسالة دكتوراه غير منشورة ، قسم إدارة مؤسسات

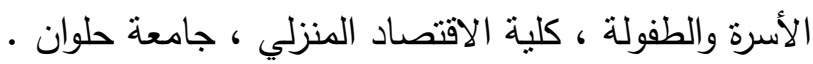

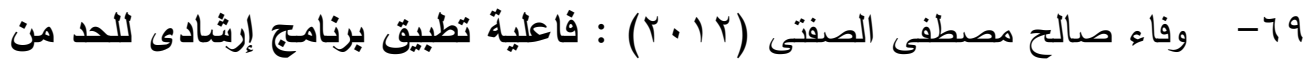
مخاطر استخدام الأدوات والأجهزة المنزلية , مجلة علوم وفنون , عدد يناير , جامعة حلوان , حلوان , مصر •

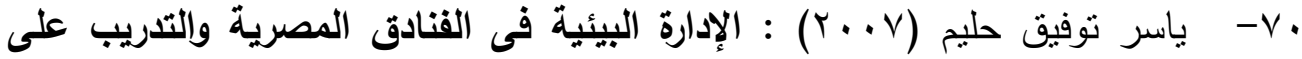

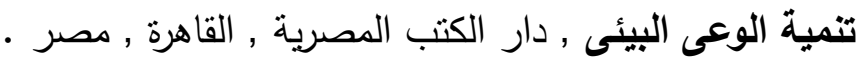

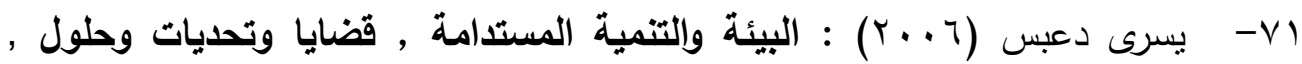
سلسلة البيئة والتتمية (7 (1) , الجزء الأول , البيطاش سنتر للنشر والتوزيع , الإسكندرية , مصر

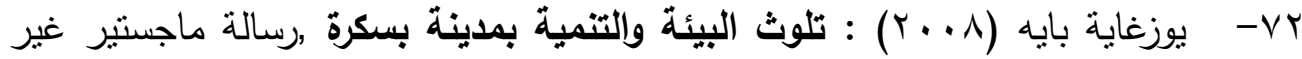
منشورة, كلية العلوم الانسانية والعلوم الاجتماعية , قسم علم الاجتماع والديموجرافيا ,

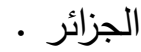


عدد خاص من مجلة "بحوث في العلوم والفنون النوعيه" القيه

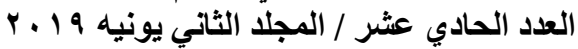

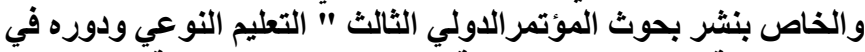

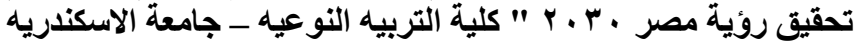

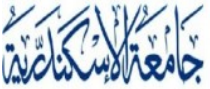

ALEXANDRIA

U N I V E R S I T Y

AlexUPress

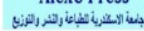

\section{ثانياً : المراجع الأجنبية :}

73-Choi , I. H(2006) : Awareness of sustainable development • why did the saemangeum tideldand reclamation project lead to the first national controversy over sustainable development in south korea, master of arts office of graduate studies of texas A\&M university.

74-Ckely, Francisco(1990) : Collaboration with unep guide lines for environmental management \& sustianble development , hand book, january .

75-Durhan, weley . $\mathrm{T}(2004)$ : The family planning communication of voluntarily , child - free - couples dissertation, abstracts international, vol 65-11a.

76-Githens , Rod , Sauer, Timothy (2010) : Going green online distance learning prepares students for success in green collar job markets, community college journal , v , 80 , n. 6 , p. 32-35.

77-Lansu,A , Sloep, J,B and Mieras,R,D.(2010): Learining in networks for Sustainabale a development ,proceedings of the Seventh International Conference on Networking Learning, Center for Learning Sciences and Technologies ,Open Universities, the Netherlands.

78-Schmidt . J . E (2007) : from intentions to actions the role of environmental awareness on college students, $\mathrm{uW}-\mathrm{L}$ journal of undergraduate research .

79-Spretnak, G . (2015) : The resurgence of the real ontario ; Addison - Wesley : Don Mills . 
عدد خاص من مجلة "بحوث في العلوم والقنون النوعيه" العزيه

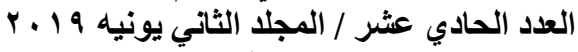

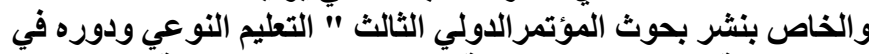

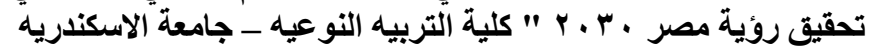

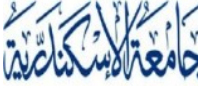

ALEXANDRIA

U N I VER S I T Y

AlexUPress

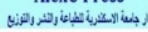

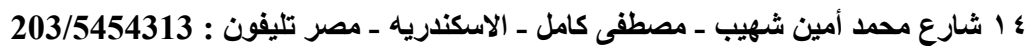
Alexandria - Egypt, Tel. : 203/5454313 - 203/5442776 Fax :203/5442776 